DEDALUS - Acervo - IGC

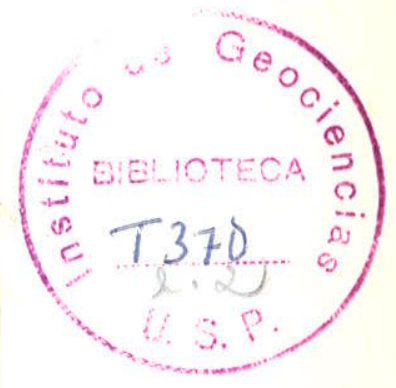

\title{
SIGNIFICAÇÃO TECTÔNICA DO MAGMATISMO ANOROGÊNICO BÁSICO E ALCALINO NA REGIÃO AMAZÔNICA
}

Dissertação de Mestrado apresentada ao Instıtuto de Geociências da Universidade de São Paulo.

Orientador :

Prof. Dr. Umberto Giuseppe Cordani 
INDICE

RESUMO

CAPITULO I - INTRODUÇÃO

CAPITULO II - METODOLOGIA

1. Anālises Potāssio-Argōnio

2. Anāitises Rubĩdio-Estrōncio

CAPITULO III - PROVINCIAS GEOCRONOLOGICO-ESTRUTURAIS NA REGIÄO AMAZŌNICA

1. Dịstribuịção geogrāfica

2. Caracterização Regional

2.1. Rochas Basais

2.2. Metassedimentos

2.3. Vulcano-P1utonismo

2.4. Rochas Sedimentares

CAPITULO IV - MAGMATISMO BASICO

1. Generalidades

2. Caracterização Geocronolōgica

2.1. Vulcanismo com idades entre 2.000 e $1.550 \mathrm{~m} . \mathrm{a}$.

2.2. Vulcanismo com idades entre 1.500 e 1.300 m.a.

2.3. Vulcanismo com idades entre 1.250 e $1.050 \mathrm{~m} . \mathrm{a}$. 35

2.4. Vulcanismo com idades entre 1.050 e $850 \mathrm{~m} . \mathrm{a}$.

2.5. Vulcanismo Cambro-Carbonífero

2.6. Vulcanismo Permo-Cretāceo

CAPITULO V - MAGMATISMO ALCALINO

1. Generalidades

2. Caracterização Geocronolōgica da Atividade prē-Cambriana 52

3. Caracterização Geocronológica da Atividade Mesozóica 60 
CAPITULOO VI - CONSIDERAÇOES FINAIS

1. Significação tectônica do vulcanismo bāsico e alcalino de idade pré-Cambriana

2. Significação tectônica do vulcanismo bāsico e alcalino de idade Fanerozóica

3. Caracterização genética do vulcanismo básico

4. Importância tectônica dos lineamentos regionais da Amazônia

BIBLIOGRAFI A

ANEXO 1

88

APENDICE 1

APENDICE IA

APENDICEE 2

\section{TABELAS}

Tabela 1 - Resultados radiométricos K/Ar para 0 magmatismo básico (10 Conjunto)

Tabela 2 - Resultados radiométricos Rb/Sr do hornfels do Diabăsio Pedra Preta

Tabela 3 - Resultados radiométricos K/Ar para 0 magmatismo básico (20 Conjunto) 
Tabela 4 - Resultados radiométricos K/Ar para o magmatismo básico ( 30 Conjuntọ)

Tabela 5 - Resultados radiométricos K/Ar para o magmatismo básico (40̣ Conjunto)

Tabela 6 - Resultados radiométricos K/Ar das rochas bāsicas Cambro-Carbonīferas

Tabela 7 - Resultados radiométricos K/Ar das rochas bāsicas Permo-Triāssicas

Tabela 8 - Resultados radiométricos K/Ar das rochas bāsicas Jurāssico-Cretāceas

Tabela 9 - Resultados Rb/Sr para o magmatismo alcalino pré-Cambriano

Tabela 10-Resultados K/Ar para o magmatismo alcalino prē-Cambriano

Tabela 11-Resultados Rb/Sr para o magmatismo alcalino Mesozóico

\section{F I GURAS}

Figura 1 - Localização da ārea estudada

Figura 2 - Mapa de localização das amostras (Anexo 2)

Figura 3 - Mapa de distribuição do magmatismo bāsico e alcalino nas províncias geocronolōgicoestruturais da região Amazōnica (Anexo 3)

Figura 4 - Distribuição geográfica dos focos magmāticos bāsicos e alcalinos durante o prē-Cambriano superior

Figura 5 - Histograma geocronolōgico para as rochas bāsicas pré-Cambrianas

Figura 6 - Zonas de fraqueza provavelmente ativas durante a evolução da provīncia Rio Negra-Juruena (1.700-1.400 m.a.). 
Figura 7 - Histograma geocronológico das rochas básicas Fanerozōicas

Figura 8 - Distribuição geogrāfica dos focos magmáticos básicos Fanerozóicos

Figura 9 - Diagrama isocrōnico Rb/Sr do sienito Canamã

Figura 10- Histograma dos teores de potássio das rochas bāsicas

Figura 11- Zonas de fraqueza ativas durante o Fanerozóico 
RESUMO

0 trabalho pretende interpretar a evolução tectōnica da região Amazōnica, com base nos modelos recentes disponíveis, e integrando as determinações radiométricas K/Ar e Rb/Sr das rochas magmäticas bäsicas e alcalinas anorogênicas, em número superior a uma centena e meia.

As provincias geocronolögico-estruturais da Amazōnia, aqui denominadas de Transamazōnica (2.000- 1.300 m.a.), Rio Negro-Juruena (1.700-1.400 m.a.), Rondoniana (1.400-1.000 m.a.) e Brasiliana (700-450 m.a.), são discut das brevemente caracterizando-se as ēpocas de seus episō dios principais (metamorfismo sintectōnico, intrusões pōs tectōnicas, vulcanismo subsequente), atravēs de isōcronas $\mathrm{Rb} / \mathrm{Sr}$.

Para as rochas bäsicas definiram-se quatro conjuntos prē-Cambrianos (2.000-1.550 m.a.,1.500-1.300 m.a., 1.250-1.050 m.a. e 1.050-850 m.a.) e dois no Paleozöico (500-300 m.a. e 260-120 m.a.). Os conjuntos pré- Cambrianos e o eo-Paleozóico são interpretados como significativos de eventos terminais dos cinturões möveis regionais e/ou magma tismo reflexo de sua atuação em āreas jā cratonizadas. Atividades magmáticas alcalinas, sobretudo no perioodo de tempo 1.500-1.150 m.a., associam-se temporalmente ao magriatismo bāsico. 0 conjunto de rochas bäsicas Permo-Cretāceas é interpretado como resultante de fenómenos associados à deriva continental e abertura do oceano Atlântico. Delimitaram- se preliminarmente dois sub-conjuntos de idade (Permo-Triássico e Juro-cretäceo), ambos com raras rochas alcalinas associadas.

Os dados radiomëtricos disponíveis para os magmatismos bāsico e alcalino prē-Cambrianos indicam que a 
estabilização tectōnica da plataforma Amazōnica somente foi atingida com o tērmino dos processos tectonomagmāticos do cinturão mōvel Rondoniano. As fontes das rochas magmāticas bāsicas foram provavelmente mais profundas entre 1.600 e 850 m.a. atrás, a julgar pelos teores mais elevados de potássio, e pẹ̣a associação temporal com o magmatismo alcalino. Constata-se ainda que os vulcanismos bäsico e alcalino prë-Cambrianos condicionam-se preferencialmente a sistemas de fraqueza com direção NE-SW e NW-SE, ao passo que aqueles de idade Mesozóica estão associados a sistemas com direção N-S e NNE-SSW. 
CAPITULO I

INTRODUÇAOO

0 conhecimento geolōgico da região Amazōnica tem crescido significativamente com o mapeamento regional do projeto RADAMBRASIL, em execução na escala 1:1.000.000.

A pesquisa geocronológica assume importāncia relevante no estudo da região Amazônica, jā que na maioria das vezes as relações de campo não são claras e em muitos casos, inexistentes. Deste modo, a determinação radiomëtrica é fator decisivo para o correto posicionamento estrati gráfico das unidades. Para o RADAMBRASIL, o apoio geocronolögico tem sido obtido atravēs de convēnio com o Centro de Pesquisas Geocronolōgicas da Universidade de São Paulo.

0 interesse do autor pela geocronologia jä vem de alguns anos, quando realizou suas primeiras determinações radiométricas no CPGeo como bolsista da Fundação de Amparo à Pesquisa do Estado de São Paulo. A partir de 1975 , contratado pelo então projeto RADAR DA AMAZŌNIA (RADAM) para executar o programa de apoio geocronolögico aos mapeamen tos efetuados, teve oportunidade de aprofundar seus conheci mentos neste campo de pesquisa. Apōs alguns anos, com o crescente acervo de dados, tornou-se viāvel a idéia de realizar sinteses regionais que auxiliassem na elucidação dos fenômenos maiores da região Amazōnica, com base nos dados geocronológicos disponîveis.

A importāncia exercida pelo magmatismo básico e alcalino, constatada quando da execução progressiva do Projeto, o duvidoso posicionamento estratigräfico de grande parte destas rochas e a inexistência de textos de caräter 
regional que analisassem o assunto sob aspecto geotectōnico-geocronolōgico, levaram o autor à realização deste trabalho, alicerçado essencialmente nas informações obtidas pelo projeto RADAMBRASIL.

Pretende-se aqui a integração de mais de uma centena de idades radiométricas de rochas magmāticas bāsicas e alcalinas da Amazōnia, visando-se uma interpreta ção para o seu posicionamento geotectōnico, fundamentada em recentes teorias evolutivas para a crosta continental. Esta compilação torna-se interessante, na opinião do autor, visto que a realização dos relatōrios do RADAMBRASIL, por ārea geogrāfica, não dịscute de modo integrado os episō dios principais que atuaram durante a evolução geológica regional.

A ārea objeto do presente estudo compreende os Estados do Amazonas e Parā, alēm de parte dos Estados do Mato Grosso e Acre. Abrange ainda os Territōrios Federais de Roraima e Amapá e quase a totalidade geogrāfica do Territōrio de Rondōnia (Figura 1). Tem por limites geogrāficos: a oeste e norte as fronteiras internacionais com a Bolīvia, Peru, Colómbia, Venezuela, Guiana, Suriname e Guiana Francesa; na sua porção meridional, os paralelos de latitude sul: 120 (na folha SC 20 Porto Velho), 12ọ (na fo Tha SC 21 Juruena) e 90 (na folha SC 22 Tocantins). A borda ocidental do geossinclīneo Paraguai-Araguaia, nas proxi midades do meridiano de longitude 50ow, define o limite oriental da àrea investigada.

Em termos geológicos abrange:

a) A parte meridional do Escudo das Guianas (em territōrio brasileiro);

b) A bacia Amazōnica;

c) 0 cráton do Guaporé, ao sul da bacia Amazōnica, entidade geotectōnica pertencente ao Escudo Brasil Central. 


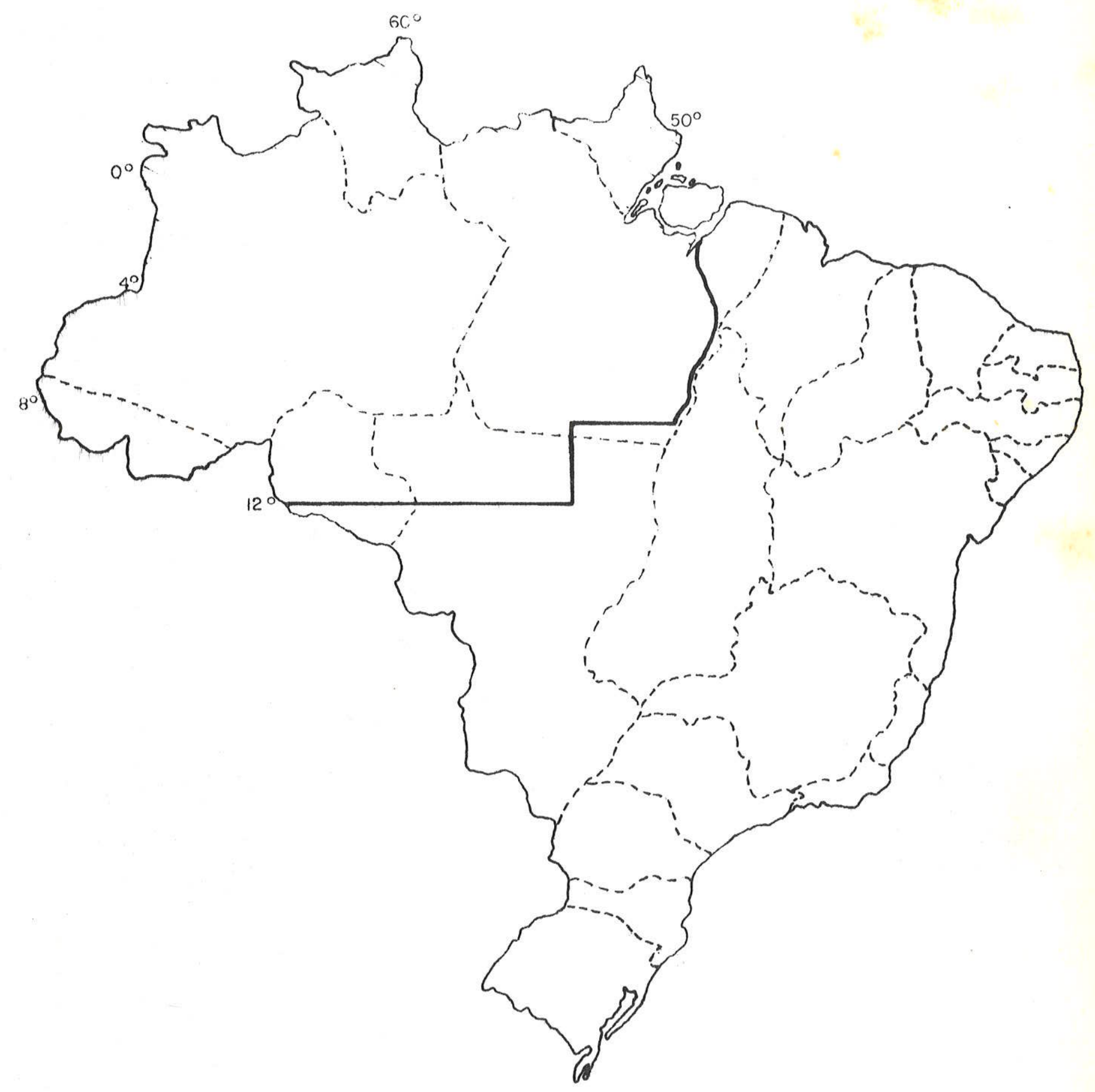

FIGURA I - LOCALIZAÇÃO DA ÁREA ESTUdADA 
A drenagem principal do Escudo das Guianas na Amazônia Legal Brasileira é representada pelos afluentes da margem esquerda do rio Amazonas sendo, os principais, os rios Negro, Jatapu, Uatumã, Nhamundä, Trombetas, Paru do Oeste, Curuá, Maicuru, Paru do Este e Jari.outros desaguam diretamente no oceano Atiāntico tais como rios Cassiporé, Calçoene e Araguari. Configurando a drena gem da margem direita do rio Amazonas tem-se os rios Juruā, Tefé, Purus, Madeira, Aripuanã, Jiparanā, Sucunduri, Tapajōs, Juruena, Teles Pires, Iriri, Xingu, Fresco e Tocantins.

A amostragem do projeto RADAMBRASIL è efetuada ao longo dos cursos d'ägua da região Amazōnica bem como nas estradas ou clareiras abertas nos interflüvios dos rios. Controle macro e micropetrográfico é realizado nas amostras obtidas, sendo posteriormente selecionadas as de interesse para análise radiomëtrica. No caso do mag matismo bäsico utilizou-se apenas o mētodo K/Ar, pela inviabilidade do método Rb/Sr. Para as rochas alcalinas empregou-se principalmente este ūitimo mētodo, sendo que, eventualmente, determinações K/Ar foram realizadas.

Integram esta sīntese 133 anālises K/Ar e 32 anāịises Rb/Sr, cujos dados analîticos estão relaciona dos nos Apēndices 1, 1A, 2 e $2 \mathrm{~A}$. A Figura 2 sumariza a $1 \underline{0}$ calização das amostras datadas.

Determinações radiométricas incluỉdas em trabalhos anteriores são aqui reavaliadas, nas interpreta ções integradas, tendo em vista os novos resultados dispo nĩvejs. As idades das rochas bāsicas pré-Cambrianas serão discutidas objetivando verificar seu relacionamento com a evolução das províncias de idade definidas por Cordani et a1. (1978 - inédito) para a região Amazōnica. Aquelas de idade pós-Brasiliana diferenciam-se geotectonicamente das 
mais antigas e serão estudadas com base no modelo proposto por Thomaz et al. (1974). As rochas alcalinas datadas na ārea em pauta, serão interpretadas tentando-se veri ficar sua vinculação com as fases vulcānicas bāsicas ca racterizadas.

E necessārio frisar que alguns dos dados ra diométricos não foram obtidos pelo RADAMBRASIL, sendo os resultados atē o momento inēditos. Diversos referem-se a convēnios realizados pelo IG-USP para execução de anāiises geocronolōgicas, e seus dados são tambēm incluídos nos Apēndices deste trabalho, que indicam as devidas refe rências. 0 Anexo 1 sumariza as referências citadas nos di versos Apēndices.

Cabe ainda dizer que serā adotada no texto a divisão proposta por Almeida (1971) para o prē-Cambriano da Amërica do Su1. O Arqueano representaria o período de tempo abrangido pelo prē-Cambriano inferior:

$$
\begin{aligned}
& \text { pE superior: } 570 \text { a } 1.800 \mathrm{~m} . \mathrm{a} . \\
& p E \text { mëdio : } 1.800 \text { a } 2.600 \mathrm{~m} . \mathrm{a} \text {. } \\
& \mathrm{pE} \text { inferior: anterior a } 2.600 \mathrm{~m} . \mathrm{a} \text {. }
\end{aligned}
$$


CAPITULO II

METODOLOGIA

A quase totalidade das determinações radiomētricas foi efetuada no Centro de Pesquisas Geocronológicas (CPGeo) da Universidade de São Paulo, utilizando-se os mētodos Potāssio-Argōnio (em minerais e em rocha total) e Rubídio-Estrōncio em rocha total (convencional e isocrónico). Excluem-se do conjunto as anālises de nọs 35 (Apêndice 1), 148 e 151 (Apēndice 2) e 157 (Apēndice 2A) devidas a Priem et a1.(1971).

1. Anāitises Potāssio-Argōnio

Compreendem a maior parte do trabalho e seus dados analitticos estão relacionados nos Apêndices 1 e 2A. Descrição pormenorizada das técnicas empregadas encontra-se em Amaral et a1.(1966).

Os teores de potássio foram obtidos atravēs de anālises em duplicata principalmente por fotometria de chama com padrão interno de lītio. Em 33 amostras utilizou-se o método da Absorção Atômica, por conveniência ana1îtica. Tais amostras acham-se especificadas no rodapé daqueles dois Apêndices. Eventualmente algumas destas amostras foram reanalisadas por fotometria de chama de modo a existir uma comparação entre os resultados obtidos pelos dois métodos.

As extrações de argônio foram executadas em unidades de ultra-alto vācuo com pressões sempre inferio- 
res a $2 \times 10^{-7} \mathrm{mmHg}$. A fusão das amostras foi obtida em temperaturas da ordem de 12009 C, correspondendo a uma corrente de 0,75 Amp. para o forno de indução do CPGeo.

As anālises de argōnio, por diluição isotó pica, foram realizadas em espectrōmetro de massa tipo Rey nolds, empregando-se como referencial aliquotas de argô nịo 38 puro em quantidades calculāveis. Os resultados obtidos no CPGeo foram calculados manualmente em calculadora eletrōnica, sendo os valores posteriormente recalculados por computador que fornece os erros analiticos das de terminações, em programa baseado na teoria da propagação de erros. As constantes empregadas nos cālculos foram:

$$
\begin{aligned}
& \lambda_{\beta}=0,530 \times 10^{-9} \text { anos }^{-1} \\
& \lambda_{\xi}=0,585 \times 10^{-10} \text { anos }^{-1} \\
& \% \text { atom. de } k^{40} \text { em } k^{\text {tot }}=0,0119
\end{aligned}
$$

A reprodutibilidade analitica das determinações K/Ar no CPGeo é controlada periodicamente através de amostras padrão e de anālises em duplicata eventuais. No caso do presente estudo, em apenas dois casos é possīvel verificar a reprodutibilidade analitica: no primeiro (amostras 61 e 63) foram utilizados dois pedaços diferentes da mesma amostra, e os resultados foram concordantes. No segundo caso (amostras 95 e 114) os dados foram discor dantes, e em falta de melhor critērio, consideramos a pos sibilidade de erro acidental na determinação de argônio de $n$ ̣ 95, tendo em vista que o outro resultado concorda meḷor com a idade de diabāsios vizinhos.

2. Anāitises Rubĩdio-Estrôncio

A maioria das determinações Rb/Sr foi efe- 
tuada em rochas alcalinas. Apenas três não se incluem nes te conjunto, pois referem-se a amostras de hornfels. Os dados analiticos completos estão relacionados nos Apêndi ces $1 A$ e 2 .

A fase analitica inicial para as amostras consiste numa britagem preliminar e posterior moagem em granulação inferior a 200 mesh. O selecionamento è feito atravēs de anālises quantitativas em rubídio total e estrôncio total, por fluorescência de raios $x$, admitindo-se erro mēdio de $2 \%$ nos valores entre 50 e 500 ppm. As idades são calculadas a partir dos resultados de rubídio total e estróncio total, e medidas de composição isotōpica de estrōncio.

Nas amostras cujas quantidades de Rb ${ }^{\text {tot }}$ e sr tot mostram-se fora do intervalo 50-500 ppm, aplica- se o método de diluição isotópica, utilizando-se traçadores enriquecidos em $\mathrm{Rb}^{87}$ e $\mathrm{Sr}^{84}$, segundo tēcnicas relatadas em Kawashita (1972).

As anālises espectromētricas foram realizadas em aparelho Varian Mat, tipo TH-5, de fonte sōlida. Suas caracteristicas acham-se descritas em Torquato $(1974)$. Os valores de $\mathrm{Sr}^{87} / \mathrm{Sr}^{86}$ foram normalizados para $S r^{86} / S r^{88}=0,1194$. As demais constantes utilizadas foram:

$$
\begin{aligned}
& \lambda_{\mathrm{Rb}}=1,47 \times 10^{-11} \mathrm{anos}^{-1} \\
& \mathrm{Rb}^{85} / \mathrm{Rb}^{87}=2,59
\end{aligned}
$$

A reprodutibilidade analitica do mētodo $\mathrm{Rb} / \mathrm{Sr}$, neste trabalho, estā representada pelas amostras de nọ 154 e 155 que acusaram resultados convencionais con cordantes. 
CAPITULO III

PROVINCIAS GEOCRONOLOGICO-ESTRUTURAIS NA REGIÁO AMAZŌNICA

1. Distribuição Geogrāfica

A Figura 3 apresenta a àrea geogrāfica obje to de estudo onde caracterizaram-se graficamente as diversas provīncias geocronológica-estruturais, as quais possuem continuidade física com os paīses vizinhos. Uma sērie de 1 ineamentos regionais seccionam a região, cabendo men cionar os seguintes: Tumucumaque, Jari-Falsino, 0iapoque, Abacaxis, Tapajōs, Canamã, Melo Nunes e Maraiuiā. Devido a sua importāncia dentro do enfoque evolutivo que se pretende discutir, encontram-se tambēm delineados na Figura as unidades vulcānicas de carāter ācido, as coberturas sedimen tares, além das principais ocorrências magmāticas bāsicas e alcalinas.

$\mathrm{Na}$ delineação destas mega-regiões foram ut $\underline{i}$ 1izados parâmetros definidos por stockwel1 (1961), (1963) e (1963a) quando da caracterização das províncias estruturais no Escudo Canadense e aqueles recentemente fixados por Kröner (1977), na definição dos "cinturões móveis" no continente Africano. O termo, segundo Anhausser (1969), é aplicāvel a cinturões metamōrficos pré-Cambrianos que possuem metamorfismo de mēdio a alto grau, deformação policīclica, granitização e possïvel retrabalhamento da crosta antiga.

Interpretação anāloga para a região Amazōnica foi ef̣etuada por Cordani et aỉ. (1978, inēdito) na qual são fixados critērios para a integração das informa- 
ções geolōgicas, estruturais e geocronológicas. Definiram se, desse modo, diversos nūcleos antigos menores, trés cinturões mōveis ("mobile belts") e uma provīncia geocronolōg i co-estrutural; o conjunto integrado representa a prōpria evolução regional da plataforma Amazōnica (Suszczynski, 1970 ).

Para a região em estudo, os nūcleos antigos ainda se encontram mal caracterizados, pois são raras as idades do embasamento com mais de $2.600 \mathrm{~m}$.a.. Zona represen tativa de crosta Arqueana ocorre por exemplo no Complexo de Imataca, na Venezuela, onde granulitos e gnaisses indicam idades entre 3.400 e $2.700 \mathrm{~m} . \mathrm{a}$.

0 cinturão móvel Maroni-Itacaiunas abrange, em territōrio brasileiro, o Amapā, a região do baixo curso do rio Tapajós e do rio Itacaiunas (Figura 3). E truncado a leste pelo geossinclíneo Paraguai-Araguaia. A característica marcante deste evento geodinâmico é ter sido afetado por uma tectónica plástica, representada nas exposições metassedimentares do Grupo Vila Nova, a norte da bacia Amazōnica, e do seu correspondente a sul, o Grupo Grão-Parā. A inexistēncia de rochas efusivas àcidas e de coberturas sedimentares de expressão è outro fator diferenciativo.0 cinturão móvel Maroni-Itacaiunas possui "trend" geral noroeste-sudeste e teve sua fase de atividade geodināmica princi pal por volta de $2.100 \mathrm{~m} . \mathrm{a}$., conforme demonstram as datações disponĩveis.

Provịncia geocronológico-estrutural com idades aparentes entre 2.200 e $1.700 \mathrm{~m} . \mathrm{a}$. é definida para a maior parte da plataforma Amazönica, recebendo o nome de Amazōnia Central (Figura 3). Sua principal característica é a presença de extensas exposições de cobertura com rochas vulcānicas ācidas e sedimentares. Esta vocação cratōni ca, aliada à própria complexidade estrutural da área, pos- 
sibilitando uma compartimentação tectōnica, levaram Cordani et al. (op.cit.) a diferenciar esta provincia geocronológico-estrutural dos cinturões móveis. Nesta provīncia ocorrem grandes estruturas de carāter regional: lineamento Tumucuma que que faz fronteira, a norte da bacia Amazônica, com o cinturão Maroni-Ittacaiunas, lineamentos Abacaxis e Tapajōs na folha SB 21 Tapajōs, lineamento Cachorro na folha SA 21 San tarēm e lineamentos Melo Nunes e Takutu nas folhas NA/NB 20 Boa Vista.

0 cinturão mövel Rio Negro-Juruena abarca tra tos das folhas NAl9 Pico da Neblina, SA 19 Içā, SC 21 Jurue na, SC 20 Porto Velho, SC 19 Rio Branco e SB 20 Purus (Figura 3). Na sua porção norte-oriental é limitado aparentemente da provīncia Amazōnia Central atravēs do lineamento Marauiā. A sul da bacia Amazōnica, na folha SC 21 Juruena, seu contato é menos preciso situando-se provavelmente, ao longo do falhamento regional de direção NNW que limita a borda sul do Grupo Beneficente.

As idades Rb/Sr disponíveis para o embasamen to cristalino, vulcano-plutonismo, depósitos sedimentares é magmatismo bāsico delimitam um perīodo de tempo entre 1.700 e 1.400 m.a. para a atuação do principal evento geodinâmico regional.

A atuação do cinturão móvel Rondoniano é caracterizada por idades $\mathrm{Rb} / \mathrm{Sr}$ entre 1.400 e $1.000 \mathrm{~m} . \mathrm{a}$., tendo atuado em parte da região anteriormente atingida pelo evento Rio Negro-Juruena (Figura 3). Esta hipōtese é reforçada pela presença de rochas metavulcānicas e granitos magmäticos transformados na região das folhas SC 21 Juruena, SC 20 Porto Velho e SB 20 Purus, região esta limîtrofe entre os doịs cinturöes. Tal fronteira é imprecisa no atual estāgio de conhecimento geológico da área. Todavia, ela parece acompanhar o alinhamento grosseiramente NS da Serra da Pro- 
vidência, para mais ao norte infletir na direção noroeste seguindo o baixo curso do rio Jiparanā. Para definição da ārea abrangida pelo cinturão metamórfico Rondoniano servem de parâmetros os depósitos sedimentares da Serra dos Pacaás Novos, as vulcānicas ācidas da região de São Lourenço-Macisa e os "trends" estruturais paralelos observados nas imagens de radar.

\section{Caracterização Regional}

Além do trabalho a respeito das provīncias geocronolōgico-estruturais da Amazōnia (Cordani et al. , op.cit.), vārios autores tēm estudado a região Amazōnica em sinteses regionais. Merecem destaque os de Suszczynski (1970), Caputo et a1. (1972), Rezende e Brito (1973), Ama ral (1974) e Almeida (1974). O desenvolvimento dos traba1hos do projeto RADAMBRASIL tem possibilitado grandes pro gressos no conhecimento geológico desta região, parte integrante da plataforma Amazōnica. Neste aspecto, destacam-se os estudos de Issler (1975a), Issler (1977), Issler et a 1. (1974) e Montalvão (1976).

\subsection{Rochas Basais}

No texto, o autor prefere não adotar, para as rochas do embasamento, termos como Complexo Guianense (Issler et a1.,1974) e Complexo Xingu (Silva et al.,1974), pois as informações disponỉveis indicam diferenças significativas na evolução geolōgica dos diversos tratos dos Escudos Brasil Central e das Guianas. Os estudos demonstram particularidades para o embasamento atravēs de varia ções geográficas laterais intimamente relacionadas às pro vīncias de idade definidas no item 1 deste capítulo,o que torna inconveniente o agrupamento genērico deste conjunto 
de rochas cristalinas. Desta forma, no presente trabalho, serão colocadas as características principais das rochas basais bem como algumas feições específicas julgadas importantes.

Associações petrotectānicas de rochas metamōr ficas de fäcies anfibolito possuem a maior extensão geográ fica na ārea em pauta. A consulta da bibliografia disponīvel indica que tais conjuntos parecem ser em grande parte policiclicos, apresentando rochas heterogēneas intensamente dobradas e são aqui interpretados como infra- estrutura de cinturães mōveis. As estruturas, em toda a Amazōnia, de monstram direções NW-SE, WNW-ESE, com variações locais para NE-SW. Na porção ocidental da região investigada (foIhas NA 19 Pico da Neblina e SA 19 Içá) predominam, no entanto, tendēncias estruturais E-W e WNW-ESE.

Migmatitos e/ou gnaisses com estruturas banda das são rochas comuns. Possuem composição variável entre granītica e granodiorîtica, apresentando a biotita e hornblenda como máficos principais. Aparecem tambēm granulitos e charnockitos, em àreas restritas, formando por vezes associação com granitos de anatexia. Estes ültimos, alēm de outras rochas graniticas, são atribuỉdos aos conjuntos basais (granito Juruena e granito Parauari). Entretanto, cum pre assinalar que $\vec{e}$ difícil distinguỉ-los de rochas simila res formadas posteriormente, nas sequências plutōnicas.

Duas unidades do embasamento merecem destaque: o gnaisse Tumucumaque (Lima et al., 1974) e o granodiorito Rio Novo (Montalvão et al., 1975), ambos situados no Escudo das Guianas. O primeiro foi individualizado pelas feições estruturais distintas, salientadas nas imagens de radar. 
indicam para o crāton do Guaporé e para sua continuidade fỉsica a norte da bacia Amazōnica, longa e complexa evolução geolōgica. Os sucessivos episōdios tectonomagmáticos (com diferentes idades) levaram a formação de migmatitos, gnaisses e granitos característicos para cada uma das provîncias geocronológico-estruturais.

A provīncia Amazōnia Central possui como particularidade geotectōnica sua vocação cratōnica, tendo atuado como ārea estāvel em relação aos sucessivos cinturões metamōrficos que se desenvolveram nas regiões adjacen tes, durante a evolução da plataforma Amazônica. Entretanto, a maioria das idades obtidas até o momento para tal provīncia, è atribuīvel a fenōmenos pós-orogēnicos do ciclo Transamazōnico, cuja significação regional é ainda incerta.

0 cinturão móvel Maroni-Itacaiunas desenvol veu-se na borda oriental da ārea pesquisada, evidenciando idades entre 2.100 e $1.800 \mathrm{~m}$. a. A Apesar de sua idade Trans amazōnica, alguns nūcleos antigos de idade Arqueana jā fó ram caracterizados.

0 evento geodinâmico Rio Negro - Juruena atuou de modo marcante na porção ocidental da região em es tudo, exibindo estruturas NW-SE, e apresentando idades entre 1.700 e $1.400 \mathrm{~m} . \mathrm{a}$.

0 ciclo metamōrfico demonstra algumas dife renças entre seus tratos meridional e setentrional. Ao sul da bacia Amazônica, é caracterizado por vulcanismo expressivo, enquanto que ao norte, rochas vulcānicas restringemse a raros afloramentos. Naquela porção, no entanto, encon tram-se provāveis depōsitos epizonais do cinturão mōvel, não se conhecendo até o presente rochas similares ao sul.

o cinturão mōvel Rondoniano teve sua atua 
ção na maior parte do Territōrio Federal de Rondōnia, apré sentando-se provavelmente superposto, em algumas regiões, ao cinturão Rio Negro-Juruena. Seu desenvolvimento teria originado os chamados granitos a duas micas, descritos recentemente por Dall'Agnol (1976). Ressalte-se que o padrão geocronolōgico do evento Rondoniano (1.400 - $1.000 \mathrm{~m} . \mathrm{a}$.$) a$ proxima-se daquele definido para o "episōdio tectonoterma 1 " diversamente denominado de Nickeriano (Priem et al.,1971a), K'Mudku (Barron, 1969) e Jari-Falsino (Lima et al., 1974) que afetou grandes porções do Escudo das Guianas.

\subsection{Metassedimentos}

Associados às rochas do embasamento, e loca lizados preferencialmente na porção oriental da Plataforma, em alguns casos ocorrendo sobrepostos, em discordância angular visivel, aparecem os metassedimentos do Grupo vila Nova (Lima et al., op.cit.) e do Grupo Grão Parā.

0. primeiro forma um conjunto de serras alinhadas aproximadamente na direção noroeste, no Territōrio Federal do Amapā. Litologicamente, são representados principalmente por quartzitos, xistos e itabiritos. Os metamor fitos do Grupo Vila Nova sofreram metamorfismo do fácies almandina-anfibolito. Os dados radiométricos Rb/Sr disponí veis indicam para estas rochas idade pröxima a $2.100 \mathrm{~m}$. a.

0 Grupo Grão Parā foi originalmente definido por Beisiegel et a'1. (1973) para englobar unidades metassedimentares da serra dos Carajās. Três unidades foram caracterizadas: Sequência paleovulcânica inferior. Formação Carajās e Sequência paleovulcânica superior. Tais rochas sofreram falhamentos nas direções NE-SW e secundariamente N-S.O fācies metamōrfico do Grupo Grão Parā ē xisto 
verde a anfibolito. Idades K/Ar em suas rochas mäficas indicam valores da ordem de $2.000 \mathrm{~m}$.a. (Gomes et al.,1975).

As duas Sequēncias metamōrficas, correlacio nāveis, incluem-se nos domīnios geogrāficos do cinturão mō vel Maroni-Itacaiunas, caracterizando a fase sintectônica de evolução do geossinclīneo Guiano-Eburneano de Choubert (1969).

Metassedimentos semelhantes ocorrem como re 1 ĩquias de erosão nas folhas NA/NB 20 Boa Vista e NA 21 Tú mucumaque, recebendo a denominação de Grupo Cauarane (Montalvão e Pithan, 197̣). Exibem fācies metamōrfico xisto verde a anfibolito, sendo representados litologicamente por quartzitos, xistos e anfibolitos. Apenas uma determina ção radiomētrica K/Ar ē conhecida para o Grupo. Trata-se de um anfibolito com cerca de 1.900 m.a., o que habilita sua correlação com os Grupos Vila Nova e Grão Pará.

\subsection{Vulcano-Plutonismo}

Sobreposto ao conjunto de rochas mais antigas tem-se expressivo episōdio vulcānico de caráter ācido a intermediārio, compreendendo principalmente riolitos, rio dacitos, dacitos, andesitos e piroclāsticas. Tais efusivas possuem ampla distribuição geográfica tanto no Escudo das Guianas como no Cráton do Guaporé (Figura 3 ), recebendo di ferentes denominações para cada ārea de ocorrēncia, mas suas maiores exposições encontram-se na provīncia Amazônia Central. Pesquisa detalhada a respeito deste vulcanismo foi recentemente realizada por Basei (1977), enfocando aspectos geocronológicos e tectōnicos.

0 vulcanismo Surumu (Barbosa e Andrade Ramos, 1959) inclui as ocorrēncias da folha NA/NB 20 Boa Vis 
ta. Possui continuidade para a folha NA 21 Tumucumaque onde é denominado de vulcanismo Iricoumé (01iveira et al.,1975). 0 evento, datado atravēs de isōcrona Rb/Sr em rocha total em cerca de $1.900 \mathrm{~m} . \mathrm{a}$. (Basei, op.cit.), representa o vulca nismo subsequente à implantação do cinturão mōvel Maroni Itacaiunas, estando seus registros preservados em territō rio brasileiro somente nestas duas regiões.

A presença de vulcanismo com diferentes idades no Escudo das Guianas e os depósitos sedimentares tempo ralmente relacionados indicam longa duração para o fenômeno ỉgneo-sedimentar. Exemplificando o fato, ocorrem sobrepos tos ao vulcanismo Transamazōnico, os sedimentos do Grupo Roraima, ao passo que na ārea de ocorrēncia do vulcanismo mais jovem (1.600 m.a.; Priem, 1973), no Suriname, tem-se o depōsito de Tafelberg.

0 vulcanismo Uatumã (Araujo et a 1., 1976) ex põe-se nas folhas SA 21 Santarēm e SA 20 Manaus. Rochas vul cânicas relacionadas ocorrem no crāton do Guaporē, onde recoprem grandes āreas das folhas SB 21 Tapajōs, SB/SC 22 Ara guaia/Tocantins, e recebem a denominação de formação Iriri. McCandles et a 1. (1975) estudaram este evento ígneo ao qual denominaram de Complexo ígneo da região central do Pará. Ba sei (1974) e (1977) apresentou determinações radiométricas $\mathrm{Rb} / \mathrm{Sr}$, em isōcrona de referēncia, definindo a idade de 1.700 m.a. para a formação das efusivas.

Fases vulcânicas mais recentes ocorrem na fo 1ha SC 21 Juruena (com idade isocrōnica Rb/Sr de 1.550 m.a.), e na região do rio Traîra (folha SA 19 Içā) onde aparecem pequenas exposições, datadas pelo mesmo método em cerca de $1.450 \mathrm{~m} . \mathrm{a}$. (Basei, 1977). Provavelmente tais focos vulcânicos estão relacionados ao estāgio de estabilização tectônica do evento geodinâmico Rio Negro-Juruena. 
gistros de efusivas àcidas, na região de São Lourenço-Maci$\mathrm{sa}$, de idade em torno de $1.100 \mathrm{~m} . \mathrm{a}$. (isōcrona Rb/Sr), valor este representativo do vulcanismo subsequente do cinturão metamōrfico Rondoniano (Basei, op.cit.).

A migração dos focos vulcânicos para sudoeste reforça a hipōtese de uma evolução progressiva da plataforma Amazōnica de NE para SW. Basei (op.cit.) discute pormenorizadamente a evolução deste vulcanismo cratōnico, e relaciona o fenómeno ao desenvolvimento das provincias de idade, em regiões vizinhas.

Ao evento vulcānico associa-se intenso pluto nismo de caráter anorogēnico, cujas idades acompanham o quadro geocronolōgico das efusivas. No Escudo das Guianas, o plutonismo apresenta-se geralmente sob a forma de stocks e,por vezes, de batōlitos. Possuem larga distribuição nas folhas NA/NB 22 Macapā, NA 21 Tumucumaque, SA 21 Santarém, SA 20 Manaus e na parte norte-nordeste da folha NA/NB 20 Boa Vista. Constata-se que as vulcânicas com cerca de 1.900 m.a. estão associadas à formação de granitos subvulcānicos de padrão geocronolōgico semelhante. Jā o vulcanismo "Uatumã-Iriri", datado em 1.700 m.a. (Basei, op.cit.), associase somente a plutonismo pós-Transamazōnico, no intervalo de tempo $1.700-1.500 \mathrm{~m} . \dot{a}$. (Teixeira et a1., 1976). 0s corpos anorogēnicos possuem composição variāvel, incluindo tipos graniticos, granodiorîticos e sienīticos.

No Cráton Guaporē são frequentes as intrusões de granitos, granodioritos e sienitos. Parecem coniudo, assumir maior expressão na ārea afetada pelo cinturão móvel Rondoniano, onde caracterizam importante evento cratō nico definido para a plataforma Amazōnica, com idade de 980 m.a. aproximadamente (Priem et a1., 1971). De modo genérico, para o Escudo Brasil Central, estes corpos são normalmente pequenos maciços circulares que recebem denomina- 
ções variadas por ārea de ocorrēncia. Assim, definem-se os granitos tipo Velho Guilherme, Gradaūs, Maloquinha e Teles Pires, com idades num amplo intervalo de tempo (1.700 a $1.350 \mathrm{m.a.})$.

Sob ponto de vista geotectōnico os granitos localizam-se marginal ou preferencialmente no interior das āreas afetadas pelo vulcanismo ācido a intermediārio e tam bēm condicionados ao longo ou na intersecção de falhamentos. Idēntico modo de ocorrēncia possui o magmatismo bāsico e alcalino, geneticamente associado a esforços tencionais.

\subsection{Rochas Sedimentares}

Repousando em inconformidade sobre o conjun to de rochas basais e vulcano-plutōnicas ocorrem depósitos sedimentares pré-Cambrianos que atingem grandes āreas dos Escudos Brasil Central e das Guianas. Neste ūitimo, as me 1hores exposições aparecem nas folhas NA/NB 20 Boa Vista sendo tambēm registradas ocorrēncias nas folhas NA 19 Pico da Neblina, SA 20 Manaus e SA 21 Santarēm (Figura 3). A sul da bacia Amazōnica as coberturas sedimentares, às vezes contidas em blocos de falhas impressos no embasamento, espalham-se irregularmente sobre o cráton.

0 estudo geocronolōgico destes depōsitos é efetuado de modo indireto, atravēs de datações em rochas bāsicas que os intrudem. 0 razoāvel nūmero de determinações radiométricas disponîvel tem indicado um longo perīodo de tempo para o processo sedimentar.

Os depōsitos mais antigos localizam-se na folha NA/NB 20 Boa Vista, adentrando para a Venezuela. Sugerem representar depósitos molássicos do ciclo orogênico 
Transamazōnico, pois isōcrona Rb/Sr em rocha total, $\quad \begin{array}{ll}-20- \\ \text { num }\end{array}$ hornfels do diabāsio Pedra Preta na localidade homônima em Roraima, indicou cerca de $1.800 \mathrm{~m} . \mathrm{a}$. (Basei e Teixeira, 1975 ).

Depōsitos com litologia semelhante, mas provavelmente posteriores, ocorrem nas folhas SA 20 Manaus e SA 21 Santarēm, onde são intrudidos por magmatismo bāsico com cerca de $1.400 \mathrm{~m} . \mathrm{a}$.. Sedimentos correlatos expõem- se tambēm na porção sudeste da folha NA 19 Pico da Neblina,on de recobrem em discordância angular o embasamento cristal $\bar{i}$ no daquela àrea, datado em $1.650 \mathrm{~m} . \mathrm{a}$..

Ao nosso ver, tais conjuntos sedimentares po dem representar depōsitos molassöides, resultantes da eperogênese positiva seguida de intensa fase erosiva jā nos estāgios finais de evolução do cinturão mōvel Rio Negro-Jü ruena. Os depōsitos sedimentares do Crāton do Guaporé incluỉdos neste modelo seriam: Formações Gorotire, Triunfo, Prosperança e Grupo Beneficente (Figura 3 ).

Sequēncias sedimentares mais jovens, porém ainda prē-Brasilianas, expõem-se no Territōrio Federal de Rondōnia na Serra dos Pacāas Novos, onde os derrames basā ticos definem a estratigrafia dos depósitos. Na opinião do autor, tais sedimentos estariam relacionados a estāgios fí nais de estabilização tectônica do evento Rondoniano.

Sedimentação Mesozóica no Escudo das Guianas restringe-se grosseiramente à região do Graben do Takutu, onde a Formação Takutu evidencia idades entre o Jurässico superior e cretāceo inferior. Recobrindo o alinhamento tec tōnico Takutu e grandes āreas nos interflūvios Branco-Uraricoera e Takutu-Surumu aparecem ainda coberturas Cenozóicas. 
tambēm na porção sul e sudeste do crāton do Guaporē, na região da rede hidrográfica dos altos cursos dos rios Roosevelt, Juruena, Teles Pires e Xingu, representados pela Forma ções Parecis e Araguaia, do Cretáceo e Terciārio respectivá mente. Depósitos aluvionares recentes são encontrados prati camente em todos os rios que drenam a área estudada. 
CAPITULO IV

MAGMATISMO BÄSI CO

1. Generalidades

Atividade magmātica bāsica sob a forma de diques, sills, pequenos stocks e derrames atingiu indistintamente o Escudo das Guianas e o Crāton do Guaporé em vārios perīodos da evolução geológica regional. Analogicamente com processos magmáticos similares, as rochas bāsicas teriam se originado no manto superior e ascendido atravēs de fraturas profundas, geneticamente relacionadas a fenômenos de tração da crosta continental.

Sua distribuição foi a mia is ampla possível, na região Amazônica. No Escudo das Guianas afetou principalmente a porção norte do Territōrio Federal de Roraima,o vale do rio Mapuera e os interfiūvios Trombetas-Cachorro e Trombetas Turuma (Figura 3). No Territōrio Federal do Amapā ocorre exemplo notāvel definido por um enxame de diques básicos dis postos paralelamente segundo $\mathrm{N}-\mathrm{S}$ por cerca de $200 \mathrm{~km}$ de extensão. No crāton do Guaporé destacam-se os derrames na Serra dos Pacaás Novos e as ocorrências nos vales dos rios siri quiqui, Curuquetê, Aripuanã, Fresco e Itacaiunas (Figura 3) .

Até o presente são disponīveis, no total, 126 determinações radiométricas K/Ar para as rochas bäsicas da Amazônia, relacionadas no Apēndice 1. Três determinações $\mathrm{Rb} / \mathrm{Sr}$ foram efetuadas em rochas termometamōrficas, associadas a um dos corpos do "Diabásio Pedra Preta", e seus dados encontram-se no Apêndice 1A. A Figura 2 posiciona a amostragem e as Figuras 4 e 8 esquematizam a distribuição dos focos magmáticos segundo intervalos de tempo. Histograras de teores de 
potāssio para o magmatismo estão na Figura 10 .

De modo geral, para rochas que sofrem resfria mento rāpido, as idades K/Ar são representativas de sua ēpō ca de formação. Certas fases minerais retēm quantitativameñ te o argōnio acumulado ( é o caso dos plagioclásios), enquanto que outras podem sofrer perdas parciais do gás nobre. Desta forma as rocha totais, quando analisadas pelo método $\mathrm{K} / \mathrm{Ar}$, representam apenas valores mỉnimos em relação à sua época de formação. Entretanto, na falta de elementos adicionais interpretativos, o autor considerará, em princīpio,os resultados como prōximos das idades reais de formação.

Os dados geocronológicos permitem distinguir vārios conjuntos, de idade pré-Cambriana e mais jovens (Figuras 5 e 7). Neste capītulo serā feita uma descrição das principais ocorrēncias na ārea investigada. Note-se que o magmatismo recebe diferentes denominações em função de sua idade presumida elou localização. A caracterização petrográ fica genērica aqui apresentada fundamenta-se nos estudos da equipe de petrografia do RADAMBRASIL.

2. Caracterização Geocronolōgica

0 magmatismo prë-Cambriano (Figura 5) apresen ta 66 determinações $\mathrm{K} / \mathrm{Ar}$ (Tabelas 1,3,4 e 5) para a região em estudo. Os resultados variam num amplo intervalo de tempo, entre 2.000 e $850 \mathrm{~m}$. a. aproximadamente. 0s dados analiticos mostram-se geralmente satisfatōios, com erros percen tuais inferiores a $5 \%$. Apenas 4 resultados (nọs $30,31,40$ e 42, Apēndice 1) perdem quanto à qualidade de anāilise, porēm não merecem maior restrição interpretativa, visto que suas idades aparentes situam-se dentro dos padrões geocrono 1ógicos observados para o conjunto de rochas básicas. Obser 
vando os dados radiométricos disponiveis, constatam-se 39 a näitises em rocha total (granulometria 35-60 mesh), 23 em plagioclāsio (60-100 mesh) e apenas uma em anfibōiio (60100 mesh). 0 histograma da figura 5 parece evidenciar a existēncia de pelo menos 4 ciclos magmāticos distintos, cada um com aproximadamente 200 m.a. de duração. Entretanto, não pode ser excluỉda a hipōtese de que com o aumento do nū mero de datações, possam vir a ser preenchidos os intervalos de tempo ainda sem registros na ārea investigada, definindo a ocorrência de fenōmenos vulcānicos sucessivos e mais ou menos contínuos no tempo.

No caso do magmatismo Fanerozōico são disponỉveis 60 determinações radiométricas K/Ar (Tabelas 6, 7 , e 8). As anālises foram efetuadas em rocha total (39) e em plagioclásio (21). Os resultados mostram-se em geral satisfatörios, apesar de aparecerem, em diversos casos, elevados erros percentuais nos valores de idade ( $n$ o s 75, 78, 80, 84, $92,100,101,105,107,113,115,122)$. As anāitises de nọs 68,69 e 78 representam o derrame basāitico existente na re gião de Tucuruí. Dois resultados (nọs 68 e 69) evidenciaram valores concordantes, ao passo que o outro (no 78) indicou idade mais jovem, atribuível provavelmente à alteração intempērica constatada na amostra. Por esta razão, este ūitimo resultado serā excluído da interpretação. Outra anālise ( nọ 126) não serā levada em conta tendo em vista a elevada percentagem indicada de argōnio 40 atmosférico (Apēndice 1). Finalmente, foi abandonado o dado relativo à amostra nọ 95, conforme explicado no capítulo II.

No histograma das determinações radiomētricas Fanerozōicas (Figura 7), excluídas as anālises de nọs 78, 95 e 126 acima referidas, caracterizaram-se vārias con centrações de idades provavelmente significativas no contex to evolutivo regional. Delinearam-se pelo menos dois āpices vulcānicos bem definidos e um terceiro conjunto compreenden 
do diversos resultados esparsos. Na definição temporal destes ciclos foi levado em conta o número de resultados dispo nỉveịs, bem como a concentração de idades numa determinada ēpoca geolōgica. 0 intervalo mais antigo (com idades entre - Cambriano e o Carboniffero) encontra-se mal definido, e apresenta um ūnico āpice por volta de 500 m.a.. No futuro, com maior número de dados geocronológicos, poderá eventualmente tentar-se uma divisão daquele período de tempo em vários intervalos, correspondentes a eventos vulcānicos distintos. Os dois āpices mais jovens, com elevado nūmero de idades concentradas entre o Permiano inferior e o cretāceo inferior, jā haviam sido anteriormente caracterizados por Thomaz et al. (1974).

\subsection{Vulcanismo com idades entre 2.000 e 1.550 m.a.}

Para o conjunto de vulcānicas bāsicas mais antigas, foram obtidas dez determinações radiomētricas K/Ar (Tabela 1), alēm de três anālises Rb/Sr (Tabela 2). Os dados K/Ar distribuem-se entre 2.000 e 1.550 m.a., aparecendo porēm uma aparente concentração de idades no intervalo de tempo $1.950-1.850 \mathrm{~m} . \mathrm{a}$. (Figura 5). Constatação interessan te pode ser notada pelo exame da Tabela 1 onde dois dos pla gioclásios analisados ( $n O \mathrm{~s} 1$ e 2 ) indicam valores radiométricos mais antigos que os obtidos nas rocha totais de básicas de regiões vizinhas ( $n$ ọs 4,5 e 6 ), o que reflete pro vavelmente certa perda de argōnio por parte destas últimas.

Todas as rochas bāsicas deste conjunto mais antigo, algumas das quais com idades caracteristicas do ciclo Transamazōnico, situam-se no interior da província Amazōnia Central, em especial no Territōrio Federal de Roraima, ou no interfiūvio Tapajōs-Jamanxim (Figura 4).

$\mathrm{Na}$ opinião do autor, os valores Transamazōn cos da região de Roraima são geologicamente significativos, 


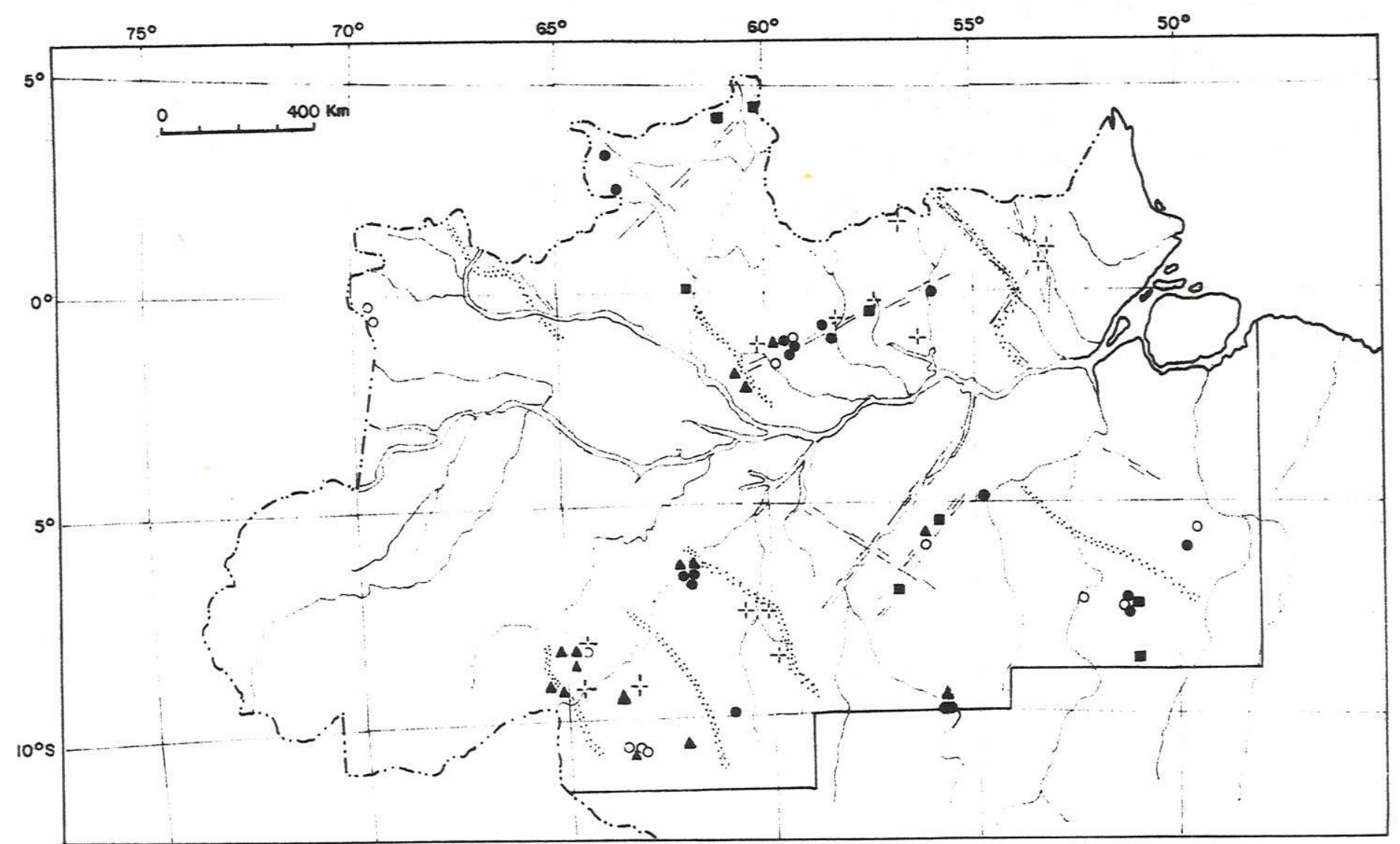

\section{LEGENDA \\ O $1050-850$ \\ A $1250-1050$ \\ - $1500-1300$ \\ - $>1550$}

ROCHAS BÁSICAS (m.a.)

$\bigoplus$ ROCHAS ALCALINAS

FIGURA 4 - DISTRIBUIÇÃO GEOGRÁFICA DOS FOCOS MAGMÁTICOS BÁSICOS

E ALCALINOS DURANTE O PRÉ-CAMBRIANO SUPERIOR. 


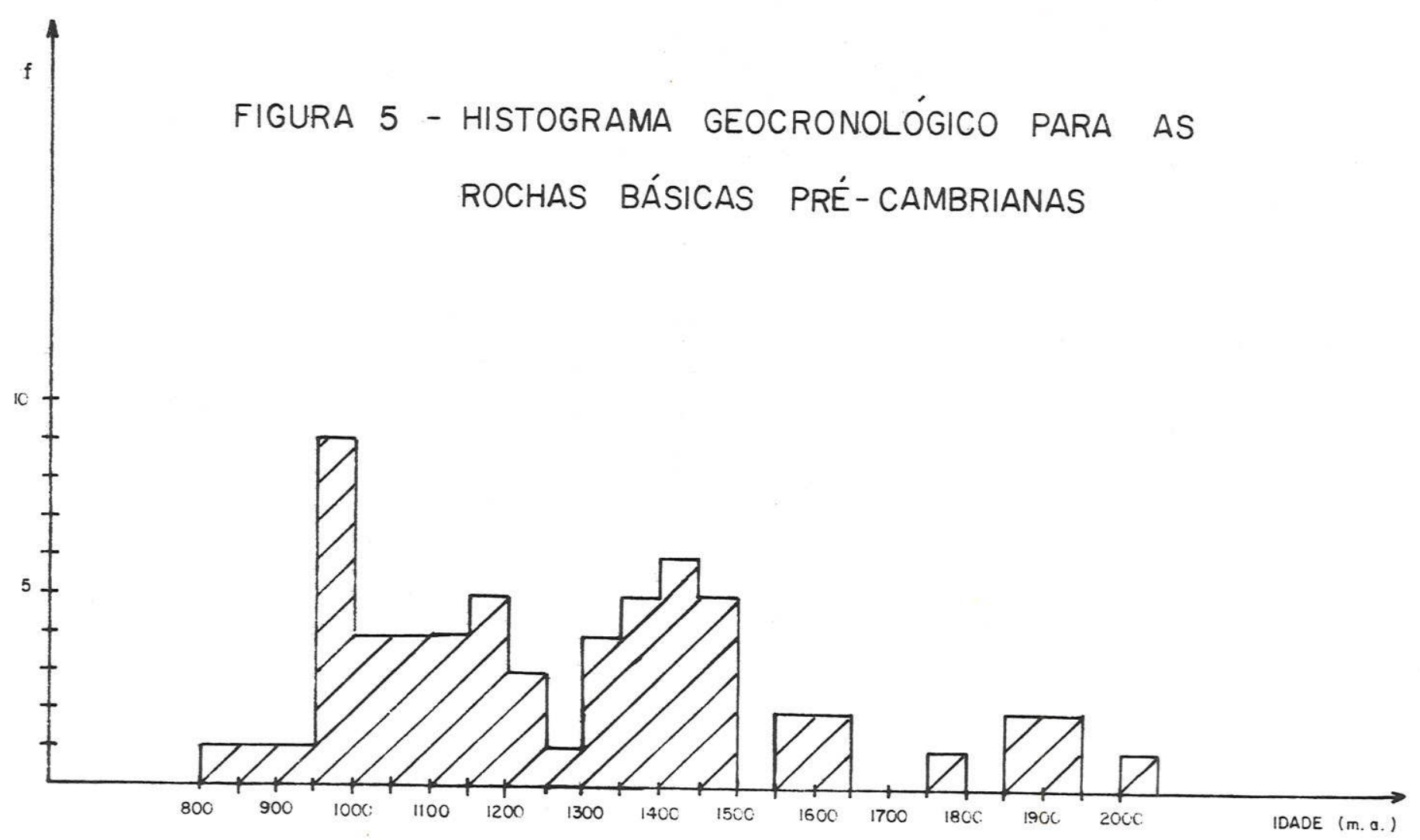


TABELA 1 - RESULTADOS RADIOMETRICOS K/Ar PARA O MAGMATISMO BÁSICO ( 19 CONJUNTO )

$\begin{array}{clllll}\text { Nọ Ordem } & \text { Nọ Campo } & \text { Litologia } & \text { Mineral } & \% \text { K } & \text { Idade (m.a.) } \\ 1 & \text { SACHX263 } & \text { Dolerito } & \text { PLAG. } & 1,11 & 2.000 \pm 95 \\ 2 & \text { PTB/UC19 } & \text { Hip.01iv.Diabäsio } & \text { PLAG. } & 0,10 & 1.946 \pm 57 \\ 3 & \text { N5F7 } & \text { Diabāsio } & \text { RT } & 2,65 & 1.905 \pm 58 \\ 4 & \text { RR68 } & \text { Diabāsio } & \text { RT } & 0,72 & 1.891 \pm 69 \\ 5 & \text { MIF03 } & \text { Diabāsio } & \text { RT } & 0,75 & 1.886 \pm 40 \\ 6 & \text { RR67.3 } & \text { Diabāsio } & \text { RT } & 0,50 & 1.757 \pm 81 \\ 7 & \text { PNJF04 } & \text { Gabro } & \text { PLAG. } & 0,34 & 1.646 \pm 55 \\ 8 & \text { RR148 } & \text { Gabro } & \text { RT } & 0,91 & 1.635 \pm 60 \\ 9 & \text { RR70.1 } & \text { Diabāsio } & \text { RT } & 0,71 & 1.574 \pm 60 \\ 10 & \text { CREI40 } & \text { Diabāsio } & \text { PLAG. } & 1,57 & 1.553 \pm 26\end{array}$

TABELA 2 - RESULTADOS RADIOMETRICOS Rb/Sr DO HORNFELS DO DIABÁSIO PEDRA PRETA

$\begin{array}{cccccc}\text { No } \text { Ordem } & \text { No Campo } & \text { Litologia } & \mathrm{Sr}^{87} / \mathrm{Sr}^{86} & \mathrm{Rb}^{87} / \mathrm{Sr}^{86} & \text { Idade (m.a.) } \\ 11 & \text { MM96 } & \text { Hornfels } & 0,8778 & 6,33 & 1.830 \pm 60 \\ 12 & \text { MM95 } & \text { Hornfels } & 0,8412 & 5,07 & 1.800 \pm 70 \\ 13 & \text { MM94 } & \text { Hornfels } & 0,8254 & 4,50 & 1.800 \pm 70\end{array}$


- que é corroborado pelas dados Rb/Sr obtidos por Basei e Teixeira (1975) em hornfels do "Diabāsio Pedra Preta" (Tabe 1 a 2), com idades aparentes de cerca de $1.800 \mathrm{~m} . \mathrm{a}$.. As três anälises Rb/Sr, pelas suas elevadas relações $s r^{87} / S r^{86}$, são confiāveis mesmo ao se admitir razões iniciais levemente di ferentes de 0,705 (valor adotado nos cálculos). Desta forma, pelos dois métodos K/Ar e Rb/Sr, pode ser demonstrada uma atividade magmātica bāsica contemporānea à fase pōs-tec tōnica principal do ciclo Transamazōnico.

0 exame do histograma (Figura 5) permite ainda evidenciar a existência de quatro idades pouco mais jovens do que as mencionadas, com valores entre 1.650 e 1.550 m.a. (Tabela 2), atribuíveis à recorrência de atividades magmāticas, não podendo ser excluída a hipōtese de possível ocorrência de perdas parciais de argōnio, abaixando artificialmente as idades aparentes K/Ar.

No Escudo das Guianas, folha NA/NB Boa Vista, ocorre o vulcanismo Pedra Preta-Araí na forma de diques e sills, incluindo-se na unidade o dique básico da Serra do Araí, o sill do monte Roraima e os stocks bāsicos da região do Surucucu. Sua extensão geogrāfica pode ser observada nas Figuras 3 e 4 , onde pode constatar-se a orientação preferen cial NW-SE das estruturas, tais como o lineamento Melo Nunes. 0 vulcanismo básico no Territōrio de Roraima tem sido estudado há longo tempo. 01 iveira (1929), Guimarães (1929), (1930) e (1947), e Paiva (1939), realizaram os primeiros es tudos destas rochas, e posteriormente Barbosa e Ramos (1959) utilizaram o termo "vulcanismo Roraima" para definir o conjunto de intrusões bāsicas no espesso depōsito de arenitos prē-Cambrianos da região norte do territōrio. Trabalhos recentes foram efetuados por Braun e Rangrab (1972), e Monta 1 vão et al. (1975). Neste ültimo trabalho propōs-se o termo "Diabāsio Pedra Preta" para denominar a unidade anteriormen te mapeada no Brasil como vulcanismo Roraima. Os estudos efetuados por Guimarães (op.cit.) caracterizaram petrografi- 
camente as rochas bāsicas da região de Pedra Preta-Araí como diabāsios, diabásios noríticos e noritos, que podem ou não apresentar olivina.

No Crāton do Guaporé, folhas SB/SC 22 Araguaia-Tocantins e SB 21 Tapajōs, rochas vulcânicas com idade superior a $1.550 \mathrm{~m} . \mathrm{a}$. aparecem raramente, sendo impossível no momento uma caracterização similar aquela efetuada para o Escudo das Guianas. Os casos assinalados referem- se a diques orientados segundo NNW-SSE, provavelmente condicio nados a sistemas paralelos ao lineamento Abacaxis (Figura 3), cuja direção e concordante com as estruturas do cinturão móvel Maroni-Itacaiunas, de idade Transamazônica.

Estudos geocronolōgicos de intrusivas bāsicas têm sido efetuados por diversos pesquisadores também nos paises vizinhos, principalmente no Suriname e nas Guianas, tendo como um dos principais objetivos o posicionamento estratigräfico de sedimentos prë-Cambrianos. Neste contexto, destacam-se os trabalhos de McDougall et al. (1963), Snelling e McConnell (1969) e C.Martin Bellizzia (1972). Es te ūitimo trabalho apresenta uma isōcrona para rochas bāsicas intrusivas na "Formação Roraima", com idade de 1.695 m.a. Pesquisa geocronológica detalhada a respeito de idades K/Ar em rochas bāsicas foi elaborada por Hebeda et al. (1971) na caracterização do dolerito de Avanavero no Surina me. Alēm de definirem uma idade próxima a 1.600 m.a. para a intrusão, demonstraram a presença de argônio radiogēnico em excesso, responsāvel por idades mais antigas. Entretanto, tal raciocínio não pode ser generalizado para qualquer valor K/Ar maior que $1.600 \mathrm{~m} . \mathrm{a}$. do Escudo das Guianas, tendo em vista pelo menos as datações acima referidas do "Diabásio Pedra Preta". Na opinião do autor, o exemplo de Avanave ro deve representar um caso isolado de argōnio em excesso,e devido à situação geológica particular da intrusão, de dimensões fora do normal. 
2.2. Vulcanismo com idades entre 1.500 e 1.300 m.a.

0 segundo conjunto vulcānico, cujos resultados K/Ar situam-se entre 1.500 e 1.300 m.a. (Tabela 3), é constituīdo por 21 datações (Figura 5). As idades distribuem-se em todo o intervalo de tempo acima referido, não havendo definição de āpices de magmatismo. Valores elevados de potāssio foram verificados para 13 amostras ( 0 os 14,17 a $25,28,31$ e 33 ), sugerindo relacionamento genético com o magmatismo alcalino.

0 intervalo geocronológico caracterizado habilita um relacionamento temporal com os eventos tecto-orogēnicos da faixa mável Rio Negro-Juruena (definido no capītulo III). Assim, parece estar demonstrada a existēncia de fenōmenos magmáticos anorogênicos, reflexo do desenvolvimen to do mencionado cinturão metamōrfico, sobre vārias regiões da provīncia Amazônia Central, que na época constituia-se no seu antepaîs.

A Figura 6 evidencia os principais sistemas de fraqueza provavelmente ativos durante a evolução do episōdio geodināmico Rio Negro-Juruena (1.700 - 1.400 m.a.), traçados com base nas direções estruturais de rochas bāsicas com idades compreendidas no segundo conjunto radiométri co definido acima. Foram seguramente importantes neste contexto os lineamentos Cachorro e Tapajōs (de direção NE-SW) e a falha do Canamã (NW-SE). 0 exame simultāneo das Figuras 4 e 6 evidencia o longo perīodo de atividade vulcânica (básica e alcalina) destas zonas de fraqueza, as quais apresen tam focos magmāticos desde o Transamazōnico até cerca de 900 m.a., tendo sido inclusive reativadas em ēpocas posteriores.

As determinações radiomētricas K/Ar disponīveis demonstram a amplitude regional do vulcanismo com 
TABELA 3 - RESULTADOS RADIOMETRICOS K/AR PARA 0 MAGMATISMO BÁSICO ( 29 CONJUNTO )

No Ordem Nọ Campo Litologia Minera

Idade (m.a.)

\begin{tabular}{|c|c|c|c|c|c|c|}
\hline 14 & $6 / 628 / 69$ & Diabāsio & RT & 2,14 & 1.496 & \pm 55 \\
\hline 15 & PA39.3 & Diabāsio & $\mathrm{RT}$ & 0,44 & 1.492 & \pm 16 \\
\hline 16 & AM 310 & Diabāsio & RT & 0,79 & 1.491 & \pm 31 \\
\hline 17 & N5F 7 & Diabäsio. & $\mathrm{RT}$ & 5,37 & 1.488 & \pm 13 \\
\hline 18 & AS229B & Diabāsio & RT & 2,27 & 1.475 & \pm 65 \\
\hline 19 & $23 A 66$ & Gabro & RT & 1,99 & 1.439 & \pm 38 \\
\hline 20 & РТ26. 2 & Diabāsio & RT & 1,78 & 1.429 & \pm 16 \\
\hline 21 & PT292D & Diabāsio & PLAG. & 1,28 & 1.420 & \pm 58 \\
\hline 22 & PTJ 8 & Diabāsio & PLAG. & 1,09 & 1.420 & \pm 32 \\
\hline 23 & PT36 & Metadiabāsio & RT & 1,63 & 1.420 & \pm 22 \\
\hline 24 & TR79 & Diabāsio & RT & 1,85 & 1.408 & \pm 50 \\
\hline 25 & PT17 & Diabāsio & PLAG. & 2,93 & 1.385 & \pm 39 \\
\hline 26 & PTJ7 & Diabāsio & RT & 0,78 & 1.376 & \pm 19 \\
\hline 27 & РT21B & 01 iv. Diabāsio & PLAG. & 0,76 & 1.375 & \pm 37 \\
\hline 28 & РТ26. 1 & Basal to & RT & 2,14 & 1.366 & \pm 18 \\
\hline 29 & РТ18.1 & 01 iv.Diabāsio & PLAG. & 0,66 & 1.366 & \pm 15 \\
\hline 30 & CUJ-1 & Diabāsio & $\mathrm{RT}$ & $.0,70$ & 1.336 & \pm 65 \\
\hline 31 & IMM 30C & Basalto & RT & 1,21 & 1.333 & \pm 67 \\
\hline 32 & CB 15 & Diabāsio & RT & 0,88 & 1.333 & \pm 43 \\
\hline 33 & CB 11 & Diabäsio & RT & 2,76 & 1.321 & \pm 58 \\
\hline 34 & CB 19 & Gabro & PLAG. & 0,79 & 1.272 & \pm 20 \\
\hline
\end{tabular}




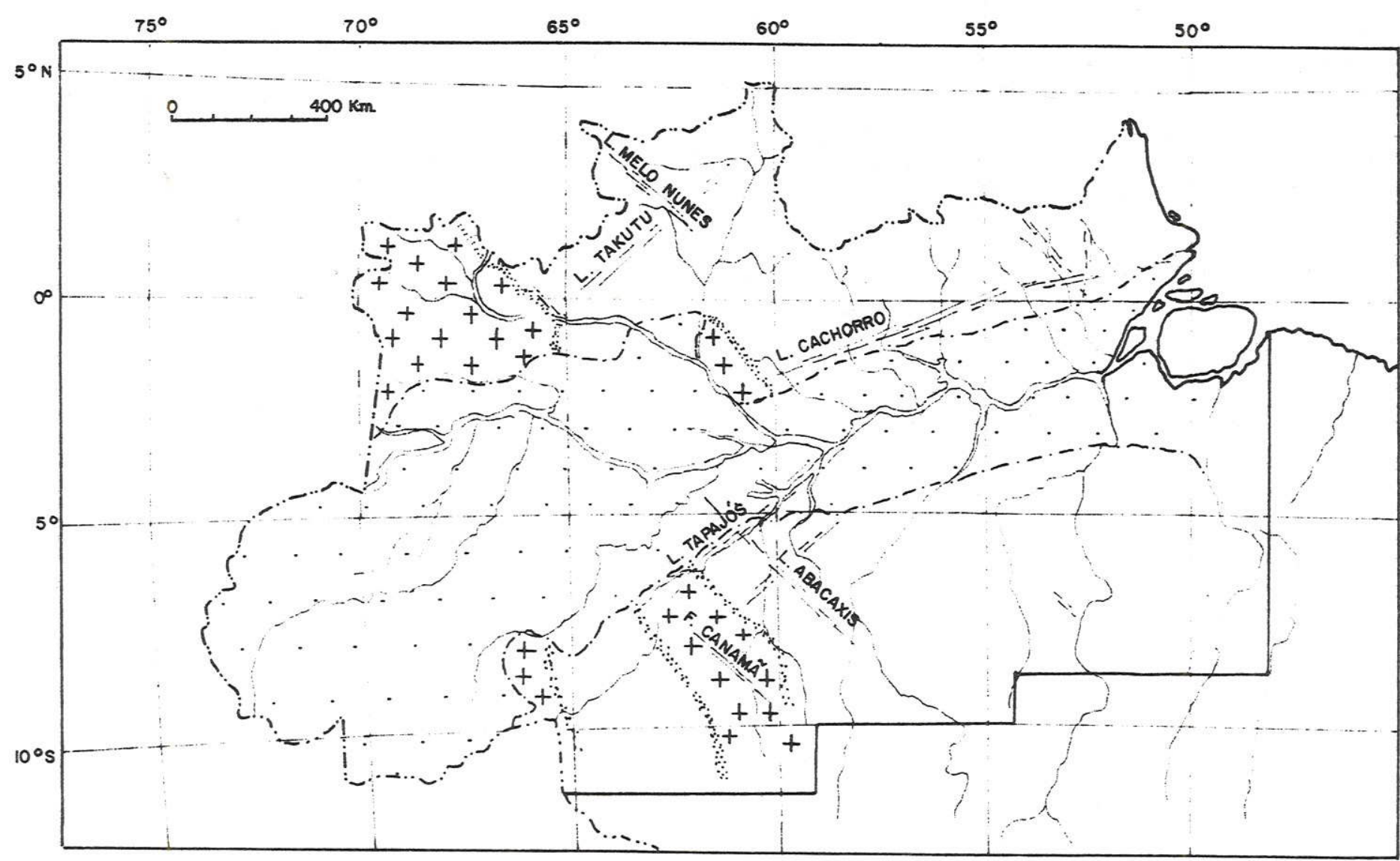

\section{LEGENDA}

. . Bacia Amazônica

$\left[\begin{array}{c}+ \\ ++\end{array}\right.$ ałuação do evento

FIGURA 6 - zONAS DE FRAQUEZA PROVAVELMENTE ATIVAS DURANTE A EVOLUÇÃO DA PROVINCIA RIO NEGRO-JURUENA (1.700- 1.400 m.a.). 
$1.500-1.300 \mathrm{~m} . \mathrm{a}$. , que afetou diversas āreas das folhas NA/ NB 20 Boa Vista, SA 20 Manaus, NA 21 Tumucumaque, SA 21 Santarēm, SB 20 Purus, SB 21 Tapajös, SC 21 Juruena, SC 20 Porto Velho e SB 22 Araguaia. 0 vulcanismo ocorre sob a forma de diques, sills e stocks, intrusivos nas rochas do embasa mento, nas vulcânicas ācidas do Grupo Uatumã, e tambēm noś sedimentos antigos da Formação Prosperança. 0s diques e sills apresentam-se por vezes como verdadeiros enxames com direções NW-SE e NE-SW, enquanto que os stocks situam-se pre dominantemente na região Trombetas-Cachorro e Jatapu-Nhamundá (Figura 3).

Nas folhas NA 21 Tumucumaque e SA 21 Santarēm, as rochas bāsicas deste vulcanismo acompanham notavelmente o lineamento Cachorro, que se estende atë os limites ocidentais da folha NA/NB 22 Macapā, atingindo tambēm a porção sudeste da folha SA 20 Manaus (Figura 3). E nesta região que o evento magmático foi denominado por Araujo et al. (1976) de Gabro Suretama. Nesta ārea, os estudos petrogräficos indi cam que a unidade é composta principalmente por diabāsios é em menor quantidade por gabros, ambos podendo ou não apresen tar olivina.

As demais ocorrēncias, situadas no crāton do Guaporē, não possuem a mesma expressäo geogrāfica das que ocorrem ao norte, no Escudo das Guianas. Na região da folha SB 22 Araguaia, o magmatismo estā relacionado provavelmente com o sistema tectônico de direção NE-SW que secciona claramente aquela àrea, de que faz parte o lineamento Tapajós ( $F \underline{i}$ gura 3). Na folha SB 20 purus, afloramentos de rochas básicas com este padrão geocronológico restringem-se à zona assu mida como limītrofe entre o cinturão móvel Rio Negro-Juruená e a provincia Amazônia Central, cujas estruturas são concordantes com a da falha do Canamã (NW-SE). 
2.3. Vulcanismo com idades entre 1.250 e 1.050 m.a.

Este terceiro conjunto de idades acha-se bem caracterizado no histograma da Figura 5. Inclui 17 determinações radiomëtricas K/Ar, sendo nove em plagioclásio, sete em rocha total e uma em hornblenda (Tabela 4 ). A observação do histograma ainda não permite definir qualquer āpice magmático, parecendo indicar um período prolongado de atividade vulcānica.

0 fenōmeno encontra-se melhor delineado, atē - momento, na região das folhas SA 20 Manaus, SA 21 Santarém, SB 21 Tapajōs, SB 20 Purus e SC 20 Porto Velho. Na por ção sudoeste desta ūitima folha ocorrem importantes derrames bäsicos que definem a estratigrafia dos sedimentos da Serra dos Pacaäs Novos. Os valores mais antigos do conjunto, entre 1.250 e $1.150 \mathrm{~m}$.a., foram caracterizados até agora apenas para as duas ūitimas regiões.

A distribuição preferencial destes focos mag máticos a sudoeste da plataforma Amazōnica (Figura 4) sugere o seu relacionamento com o cinturão mōvel Rondoniano, de finido no capitulo III. Entretanto, registros esparsos desta fase magmātica também ocorrem na ārea da província Amazô nia Central (Figuras 3 e 4 ), e preferencialmente ao longo do lineamento Cachorro. Constataçăo de interesse refere- se à presença de altos teores de potássio em värias das aınostras analisadas ( $n$ ọs de 36 a 40 , e de 43 a 47 ), reforçando a hipōtese de um relacionamento entre o magmatismo bāsico desta idade e magmatismo alcalino, tal como ocorreu para o segundo conjunto $(1.500-1.300 \mathrm{m.a}$.$) .$

Cabe ainda notar que no Escudo das Guianas é reconhecida a existēncia de um "evento tectonotermal Nicke riano", caracterizado por uma tectōnica rígida e intensa ca taclase regional, e cuja idade tem sido atribuída ao perío- 
TABELA 4 - RESULTADOS RADIOMETRICOS K/Ar PARA O MAGMATISMO BASICO ( 30 CONJUNTO )

\begin{tabular}{|c|c|c|c|c|c|}
\hline No Ordem & No Campo & Litologia & Mineral & $\% \mathrm{~K}$ & Idade (m.a.) \\
\hline 35 & RONT6 & Gabro & ANF. & 0,16 & 1.244 \\
\hline 36 & 1518AA143 & Gabro & $\mathrm{RT}$ & 1,37 & $1.243 \pm 15$ \\
\hline 37 & PT11. III & Diabäsio & PLAG. & 1,65 & $1.241 \pm 15$ \\
\hline 38 & PT60.2 & 01 iv. Diabāsio & RT & 2,07 & $1.188 \pm 13$ \\
\hline 39 & PT09. I I & Metadiabäsio & PLAG. & 2,51 & $1.167 \pm 25$ \\
\hline 40 & РT29 & 01 iv.Diabāsio & PLAG. & 2,66 & $1.164 \pm 62$ \\
\hline 41 & $1513 \mathrm{JA2} 57$ & Diabāsio & RT & 0,84 & $1.164 \pm 23$ \\
\hline 42 & PT99 & Quartzo Gabro & $P L A G$. & 0,70 & $1.153 \pm 91$ \\
\hline 43 & PT73.2 & Leucogabro & PLAG. & 1,30 & $1.132 \pm 12$ \\
\hline 44 & PT99.10 & Quartzo Gabro & PLAG. & 1,80 & $1.127 \pm 19$ \\
\hline 45 & PT06 & Leucogabro & PLAG. & 3,72 & $1.123 \pm 14$ \\
\hline 46 & РТ26. 7 & Diabāsio & RT & 1,28 & $1.108 \pm 25$ \\
\hline 47 & $1153 \mathrm{CM} 233 \mathrm{~A}$ & Basalto & RT & 1,98 & $1.098 \pm 17$ \\
\hline 48 & РТ73.1/1 & Diabāsio & RT & 0,90 & $1.095 \pm 32$ \\
\hline 49 & 1520 HM319 & Gabro & PLAG. & 0,64 & $1.090 \pm 13$ \\
\hline 50 & $1510 M P 100$ & Troctolito & $\mathrm{RT}$ & 0,41 & $1.072 \pm 18$ \\
\hline 51 & PT99.6 & Gabro & PLAG. & 1.00 & $1.050 \pm 23$ \\
\hline
\end{tabular}


do 1.300-1.100 m.a., recobrindo grande parte do intervalo de tempo caracterizado pelo terceiro conjunto vulcānico bāsico deste trabalho.

\subsection{Vulcanismo com idades entre 1.050 e 850 m.a.}

Para a atividade ïgnea bāsica pré-Cambriana de idade mais recente na ārea investigada dispõe-se de 15 determinações aparentes K/Ar (Tabela 5). A maioria das anālises foi efetuada em rocha total, sendo apenas quatro obti das em plagioclāsio.

Somente duas das anālises merecem comentārio especĩfico (nọs 65 e 66). Suas idades aparentes são anômalas em relação ao padrão obtido até o momento para a ārea, porēm foram feitas em plagioclāsio, que é bom retentor para argōnio, e seus resultados são praticamente iguais ( apesar das duas rochas estarem distantes entre si). Na opinião do autor, estes fatos são suficientes para sugerir que tais re sultados sejam geologicamente significativos.

0 histograma da Figura 5 demonstra uma concen tração das idades aparentes por volta de $1.000 \mathrm{~m} . \mathrm{a}$. , sugerindo ser esta a época principal para o fenômeno. A definição do limite mais antigo deste agrupamento (1.050 m.a.) é imprecisa, pois há recobrimento aparente com o ciclo anterior. Todavia, não pode ser excluída a possibilidade de que os dois ūitimos episódios vulcānicos caracterizados (1.250-1.050 m.a., e 1.050-850 m.a.) sejam, na verdade,parte de um só conjunto de atividades vuicānicas uniformemente distribuĩdo no tempo, e com duração de cerca de $400 \mathrm{~m} . \mathrm{a}$. . Tal como foi constatado para os dois ūitimos ciclos magmäti cos bāsicos (20 e 30), elevadas percentagens de potāssió săo observadas para algumas amostras deste conjunto mais jo vem ( $n$ o 53 a 55,60 a 64 e 66$)$ ). 
TABELA 5 - RESULTADOS RADIOMETRICOS K/Ar PARA 0 MAGMATISMO BÁSICO ( 4 O CONJUNTO )

\begin{tabular}{|c|c|c|c|c|c|c|c|}
\hline NO Ordem & Nọ Campo & Litologia & Mineral & $\% \mathrm{~K}$ & Idade ( & ( $m$. & .a.) \\
\hline 52 & $1510 M P 26$ & Troctolito & PLAG. & 0,54 & 1.043 & \pm & 27 \\
\hline 53 & PA264 & Basalto & RT & 3,15 & 1.040 & \pm & 46 \\
\hline 54 & PT74 & Basalto & RT & 1,48 & 1.038 & \pm & 14 \\
\hline 55 & PT81.2 & Basa 1 to & RT & 1,85 & 991 & \pm & 10 \\
\hline 56 & 1153 AAR 332 & Basalto & RT & 0,88 & 988 & \pm & 22 \\
\hline 57 & EV14 & Diabāsio & RT & 0,71 & 986 & \pm & 47 \\
\hline 58 & PT26E & Diabāsio & RT & 0,74 & 984 & \pm & 12 \\
\hline 59 & 1153 CMR2 32 & Basalto & RT & 0,26 & 982 & \pm & 18 \\
\hline 60 & PT81.A & Basalto & RT & 1,85 & 982 & \pm & 10 \\
\hline 61 & N4F 5 & Diabäsio & RT & 3,11 & 973 & \pm & 34 \\
\hline 62 & 1153 AAR 335 & Basalto & RT & 1,07 & 967 & \pm & 17 \\
\hline 63 & N4F5 (Rep.) & Diabāsio & RT & 2,67 & 951 & \pm & 14 \\
\hline 64 & PT35A & Diabäsio & PLAG. & 1,11 & 941 & \pm & 14 \\
\hline 65 & AN84C & Diabāsio & PLAG. & 0,91 & 854 & \pm & 12 \\
\hline 66 & JF01 & Diabāsio & PLAG. & 2,45 & 839 & \pm & 22 \\
\hline
\end{tabular}


Os melhores registros deste magmatismo, atē o presente, são constatados para as regiões das folhas SA 19 Içā, SA 21 Santarēm, SA 22 Belēm, SB 21 Tapajōs, SB 22 Araguaia e SC 20 Porto Velho. A distribuição geogrāfica dos focos vulcānicos, observada na Figura 4, indica uma ocorrência preferencial nos domīnios do cinturão mövel Ron doniano, como no caso relativo ao terceiro agrupamento de idades.

\subsection{Vulcanismo Cambro-Carbonîfero}

Evento vulcānico bāsico contemporāneo com a fase pös-tectōnica do ciclo orogênico Brasiliano é representado por seis idades aparentes K/Ar (nos 67 a 72 , Tabela 6), e foi constatado, até o presente, apenas na porção oriental da ārea investigada. A observação da Figura 8 evi dencia que o fenōmeno possui expressão geogräfica preferen cial, situando-se nos domínios físicos das folhas NA/NB Ma capā, SA 22 Belém e SB 22 Araguaia, e acompanhou a borda setentrional do geossinclíneo Paraguai-Araguaia. 0 maior nümero de valores em torno de $500 \mathrm{~m}$.a. sugere que esta foi a ëpoca mais representativa para tal episōdio vulcânico (Figura 7).

Provāveis exemplos de recorrēncias magināti cas acham-se representadas no histograma por cinco resulta dos mais jovens (Tabela 6), com valores entre 420 e $310 \mathrm{~m}$. a. (excluiu-se a amostra de nọ 76, conforme comentado no item 2 deste capitulo). Os dois resultados, com idades entre 370 e $350 \mathrm{~m} . \mathrm{a}$. (amostras nọ 74 e 75 ), representam o notāvel conjunto de diques de diabāsio orientados segundo N50E que ocorrem na Serra do Taiano, folha NA/NB 20 Boa Vista. Merece ressaltar que tais diques possuem direção concordante com o lineamento Takutu (Figura 3), 0 qual exerceu importāncia decisiva no condicionamento estrutural 
TABELA 6 - RESULTADOS RADIOMETRICOS K/Ar DAS ROCHAS BÁSICAS CAMBROCARBONIFERAS

\begin{tabular}{|c|c|c|c|c|c|}
\hline O Ordem & Nọ Campo & Litologia & Mineral & $\% \mathrm{~K}$ & Idade (m.a.) \\
\hline 67 & $A A 7-37$ & Diabāsio & RT & 1,22 & $512 \pm 20$ \\
\hline 68 & AS 297 & Basalto & RT & 0,25 & $510 \pm 15$ \\
\hline 69 & AS 296 & Basal to & RT & 0,55 & $509 \pm 15$ \\
\hline 70 & OFS 74 & Diabāsio & RT & 0,68 & $507 \pm 29$ \\
\hline 71 & $66 A 66$ & Diabāsio & RT & 1,84 & $501 \pm 18$ \\
\hline 72 & JLR665 & Diabāsio & RT & 0,61 & $463 \pm 18$ \\
\hline 73 & CA 110 & Diabāsio & RT & 1,80 & $416 \pm 7$ \\
\hline 74 & RR 143 & Diabāsio & RT & 0,49 & $372 \pm 22$ \\
\hline 75 & RR226 & Diabāsịo & RT & 0,35 & $356 \pm 32$ \\
\hline 76 & 17528 & Diabásio & RT & 0,15 & $348 \pm 20$ \\
\hline 77 & FGSTIAM & Basalto & RT & 0,96 & $307 \pm 12$ \\
\hline * 78 & AP 106 & Basalto & RT & 0,61 & $300 \pm 50$ \\
\hline
\end{tabular}

Obs.: * Não considerada 


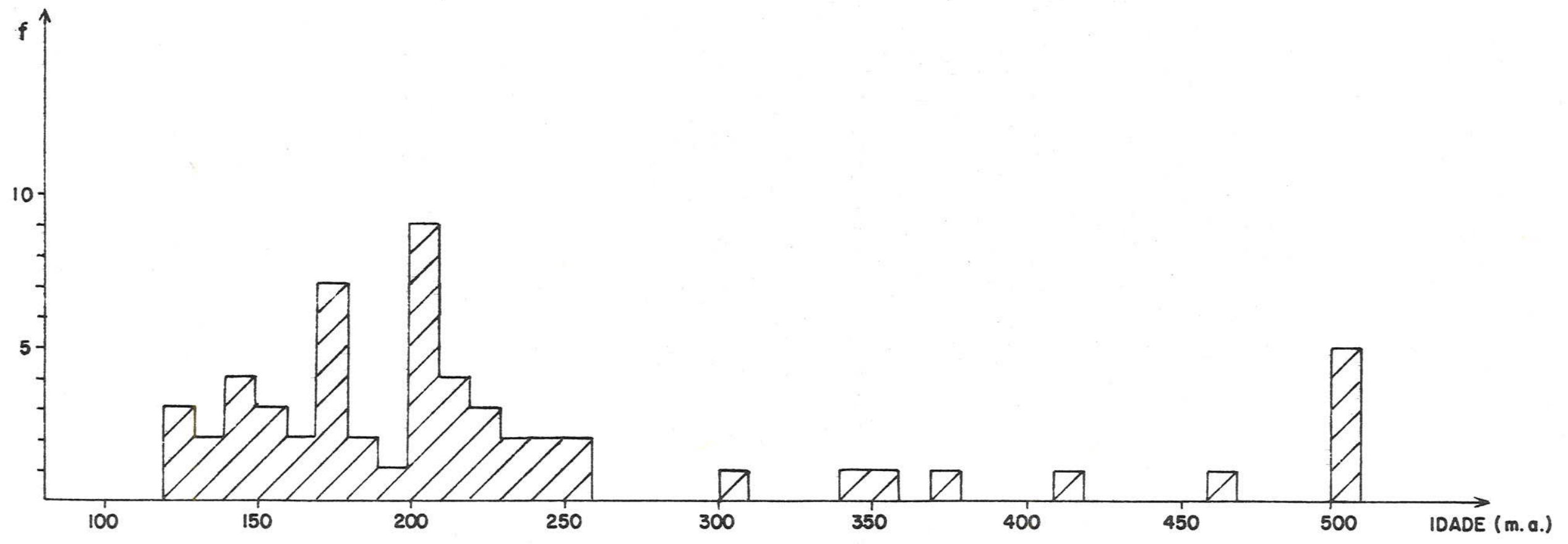

FIGURA 7 - HISTOGRAMA GEOCRONOLOGICO DAS ROCHAS BÁSICAS FANEROZÓICAS 
do Graben do Takutu.

Na Repūblica da Guiana são conhecidas idades prōximas a $400 \mathrm{~m}$. a. para diques bảsicos (Snelling e Mcconne11, 1969). Tais rochas situam-se a sudeste do Graben do Takutu e poderiam estar relacionados aos da Serra do Taiano. Por outro lado, a idade de $310 \mathrm{~m} . \mathrm{a}$. (amostra no 77), proveniente de um derrame encontrado em sub-superfície, é ainda enigmática no presente estāgio de conhecimento geológico da ārea investigada.

\subsection{Vulcanismo Permo-Cretäceo}

No Permiano inferior instalou-se sobre a plataforma Amazônica uma reativação tectonomagmātica bem caracterizada por meio das determinações radiométricas K/Ar ( Tabelas 7 e 8). 0 fenōmeno, em sua fase mais jovem, corresponde em idade a reativação Wealderiana da plataforma Sul-Ameri cana (Almeida, 1971). Nesta ültima região, o magmatismo bās co possui idades K/Ar mäximas de $150 \mathrm{~m}$.a., o que mostra que os episódios vulcānicos da plataforma Amazônica iniciaram-se muito antes. Fator distintivo adicional è a presença, na por ção sul-oriental da plataforma sul-Americana, de inūmeras in trusões alcalinas associadas ao magmatismo bāsico Fanerozóico, característica esta raramente observada na região Amazônica.

No histograma da Figura 7 verifica-se a presença de dois sub-conjuntos principais, cada um com 23 dataçōes (excluiram-se as anāitises de nọs 95 e 126 , jā comentadas no item 2 do capítulo). 0 agrupamento mais antigo possui idades aparentes K/Ar entre 260 e 200 m.a. (Tabela 7) e o mais jovem entre 190 e $120 \mathrm{~m} . \mathrm{a}$. (Tabela 8). Os ciclos vulcânicos (Permo-Triāssico e Juro-Cretāceo) são recorrentes, com mesma distribuição geogrāfica, não sendo possível tam- 
TABELA 7 - RESULTADOS RADIOMETRICOS K/AR DAS ROCHAS BÁSICAS PERMOTRIĀSSICAS

\begin{tabular}{|c|c|c|c|c|c|c|c|}
\hline NO Ordeim & Nọ Campo & Litologia & Mineral & $\% \mathrm{~K}$ & Id a de & $(\mathrm{m}$ & n.a.) \\
\hline 79 & MA1PA40 & Basalto & PLAG. & 0,22 & 259 & \pm 6 & 6 \\
\hline 80 & JLR514 & Diabāsio & PI.AG. & 0,90 & 254 & \pm 2 & 27 \\
\hline 81 & MIAB 32 & Diahāsio & PLAG. & 0,74 & 248 & \pm 4 & 4 \\
\hline 82 & I ÇEA2 4 & Diabāsio & RT & 0,75 & 242 & \pm & 5 \\
\hline 83 & MA1PA35 & Basalto & RT & 0,35 & 232 & \pm & 19 \\
\hline 84 & AA 7-2 & Dịabāsịo & RT & 0,28 & 232 & \pm & 22 \\
\hline 85 & GSD 8 & Diabāsio & PLAG. & 0,45 & 227 & \pm & 10 \\
\hline 86 & $C R / A 0372$ & Diabāsio & PLAG. & 0,51 & 224 & \pm & 17 \\
\hline 87 & PT66 I I & Diabāsio & PLAG. & 0,87 & 222 & \pm & 3 \\
\hline 88 & LAST - IAM & Diabäsio & RT & 0,40 & 219 & \pm & 7 \\
\hline 89 & PT23. I I & Diabāsio & RT & 0,40 & 218 & \pm & 8 \\
\hline 90 & ICEA42A & Diabāsio & RT & 0,76 & 213 & \pm & 2 \\
\hline 91 & IBSTIPA & Diabāsio & RT & 0,73 & 213 & \pm & 7 \\
\hline 92 & NOIAM & Basalto & PLAG. & 0,35 & 210 & \pm & 21 \\
\hline 93 & 13178 & Diabāsio & $\mathrm{RT}$ & 0,70 & 210 & \pm & 14 \\
\hline 94 & PT02A (NERL63) & Diabāsio & $\mathrm{RT}$ & 0,42 & 209 & \pm & 8 \\
\hline *95 & NOVA OLINDA & Basalto & RT & 1,79 & 208 & \pm & 14 \\
\hline 96 & JLR66 7B & Diabāsio & PLAG. & 0,18 & 207 & \pm & 18 \\
\hline 97 & RPIPA & Basalto & RT & 0,78 & 204 & \pm & 6 \\
\hline 98 & AD 405 & Diabāsio & RT & 0,75 & 203 & \pm & 6 \\
\hline 99 & PT09/EP06 & Diabäsio & PLAG. & 1,06 & 202 & \pm & 9 \\
\hline 100 & PT02 & Diabās io & $P ! A G$. & 0,79 & 201 & \pm & 23 \\
\hline 101 & RR203.4 & Gabro & RT & 0,60 & 201 & \pm & 18 \\
\hline 102 & AM7 AM & Diabāsio & RT & 0,45 & $196=$ & \pm & 7 \\
\hline
\end{tabular}


TABELA 8 - RESULTADOS RADIOMETRICOS K/AR DAS ROCHAS BÁSICAS JURASSICOCRETACEAS

Nọ

$\begin{array}{llllll}103 & \text { AB7 } & \text { Diabāsio } & \text { PLAG. } & 0,58 & 188 \pm 6 \\ 104 & \text { PTX } & \text { Diabásio } & \text { PLAG. } & 0,38 & 183 \pm 14 \\ 105 & \text { RR202.1 } & \text { Basalto } & \text { RT } & 0,83 & 179 \pm 33 \\ 106 & \text { AM104 } & \text { Diabāsio } & \text { RT } & 0,07 & 179 \pm 3 \\ 107 & \text { RTG4-67 } & \text { Basalto } & \text { RT } & 1,37 & 177 \pm 16 \\ 108 & \text { PT17C } & \text { Diabāsio } & \text { RT } & 0,98 & 177 \pm 8 \\ 109 & \text { JRL530 } & \text { Diabāsio } & \text { PLAG. } & 0,65 & 176 \pm 9 \\ 110 & \text { M114 } & \text { Diabāsio } & \text { PLAG. } & 0,31 & 175 \pm 15 \\ 111 & \text { AB4 } & \text { Diabāsio } & \text { PLAG. } & 0,71 & 171 \pm 9 \\ 112 & \text { CS2AM } & \text { Basalto } & \text { RT } & 0,61 & 165 \pm 7 \\ 113 & \text { BV-CARAC } & \text { Basalto } & \text { RT } & 0,42 & 161 \pm 17 \\ 114 & \text { N0VA 0LINDA(R) } & \text { Basalto } & \text { RT } & 1,79 & 152 \pm 13 \\ 115 & \text { 2-67-34 } & \text { Basalto } & \text { RT } & 1,37 & 151 \pm 38 \\ 116 & \text { RR221.1 } & \text { Basalto } & \text { RT } & 0,37 & 151 \pm 14 \\ 117 & \text { RR223.1 } & \text { Basalto } & \text { RT } & 1,18 & 148 \pm 9 \\ 118 & \text { RTG-2-67 } & \text { Basalto } & \text { RT } & 0,93 & 146 \pm 4 \\ 119 & \text { PT11A } & \text { Diabāsio } & \text { PLAG. } & 0,54 & 144 \pm 6 \\ 120 & \text { PT09B } & \text { Diabāsio } & \text { RT } & 0,48 & 143 \pm 6 \\ 121 & \text { MA1PA31 } & \text { Basalto } & \text { PLAG. } & 0,36 & 140 \pm 6 \\ 122 & \text { M143 } & \text { Diabāsio } & \text { PLAG. } & 0,39 & 135 \pm 53 \\ 123 & \text { AB9 } & \text { Diabäsio } & \text { PLAG. } & 0,31 & 130 \pm 6 \\ 124 & \text { RR156 } & \text { Basalto } & \text { RT } & 1,02 & 127 \pm 12 \\ 125 & \text { MA2AM } & \text { Basalto } & \text { PLAG. } & 0,33 & 126 \pm 6 \\ 126 & \text { AT36 } & \text { Gabro } & \text { PLAG. } & 0,89 & 105 \pm 15\end{array}$

Mineral

$\% \mathrm{~K}$

Idade (m.a.)

Litologia

Minera

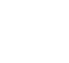


bēm uma separação em termos de percentagem de potāssio (Tabelas 7 e 8). Os dois sub-conjuntos não podem pois ser caracterizados separadamente, o que parece indicar analogia genētjca.

Em termos geogrāficos, as ocorrēncias norocidentais do magmatismo Permo-Cretāceo situam-se na folha NA 19 Pico da Neblina, constituíndo raros afloramentos no médio curso do rio Içana, na Serra do Espinho e na cabeceira do igarapé Uaranā. Formam pequenos corpos tabulares de diabāsio que seccionam os migmatitos daquela ārea (Finheiro et a 1., 1976). Registros mais expressivos do fenōmeno aparecem, no Escudo das Guianas, na sua porção centro-orienta1. No Brasil, na folha NA/NB 20 Boa Vista, e na Repúbli ca da Guiana, o vulcanismo bāsico recebe a denominação de Episōdio Takutu (Berrangē, 1973). Nas folhas NA 21 Tumucuma que e NA/NB 22 Macapá o evento recebe o nome de Cassiporé (Lima et a 1., 1974). Na folha SA 21 Santarēm e a sul, jā no Crāton do Guaporé, nos domīnios das folhas SA 22 Belëm e SB 21 Tapajōs, é denominado de Episōdio Penatecaua (Issier, et al., 1974) e na folha SC 21 Juruena, de Episōdio Cururu (Silva et al., 1974). Magmatismo similar, com ārea de ocorrência nas folhas SB/SC 22 Araguaia-Tocantins, recebe o nome de Formação Orozimbo, possuindo porém seus melhores aflo ramentos nos domīnios da bacia do Maranhão, jā fora do contexto do trabalho.

As lavas toleîticas amigdalóides ocorrem grosseiramente balizadas pelo Graben do Takutu no Territorio Federal de Roraima, e correspondem à Formação Apoteri do Episódio Takutu.

Os afloramentos do Diabāsio Cassiporé situam se, no Territōrio Federal do Amapā, principalmente en sua porção norte e nordeste. Caracterizam um notāvel enxame de diques aproximadamente paralelos, com rumos N-S e NNE-SSW, 
de composição bāsica e carāter toleītico, que cortam as rochas cristalinas e os metassedimentos do Grupo Vila Nova (Fi gura 3). Associados a esses corpos tabulares de diabásio ocorrem tambēm alguns gabros. Jā na folha NA 21 Tumucumaque, rachas bäsicas similares não apresentam a mesma magnitude de afloramentos. Ocorrem na forma de pequenos diques toleíticos de direção NNE-SSW concentrados na porção sudeste da folha. São intrusivos no embasamento cristalino e nas rochas vulcânicas e plutōnicas da àrea.

O Diabāsio Penatecaua, nos domînios da folna SA 21 Santarém, ocorre predominantemente cortando os sedimen tos Paleozóicos da bacia Amazónica, sob a forma de diques, sills e stocks. Os diques, feiçōes mais marcantes desta unidade, exibem direções preferenciais N-S, NNE-SSW e NE-SW. Suas maiores concentrações situam-se desde a região de Monte Alegre atē o interfiūvio Trombetas-Mapuera.

As exposições de rochas bāsicas na folna SB 21 Tapajōs possuem distribuição preferencial na ārea da bacia sedimentar do Amazonas, ocorrendo sob a forma de diques na região do rio Tapajōs, entre as localidades de Aveiro e Itaituba. Na porção sul da folha SB 21 Tapajōs, concentrados predominantemente na quadricula SB21YD, afloram diques de diabāsio corrẹtatos que por questão geogräfica receberam a denominação de Diabāsio Cururu. Estes diques estendem-se ain da para o sul adentrando na folha SC 21 Juruena, onde ocorrem com frequência na Serra do Cachimbo. Na porção oriental desta folha o vulcanismo básico parece possuir maior intensi dade, pois aparecem grandes diques desde a margem esquerda do rio Teles pires atë a localidade de Cachimbo, nos domīnios do Grupo Beneficente.

Os basaltos da Formação Orozimbo ocorrem, na folha SC 22 Araguaia, sob a forma de diques sem grande expressão os quais cortam as rochas do embasamento e as sequên 
cias metassedimentares.

Seguindo-se o raciocínio proposto por Thomaz et al. (1974), com o qual o autor concorda, algumas considerações podem ser feitas a respeito dos resultados radiométri cos, observando-se a distribuição geogrāfica-cronológica dos dois ciclos vulcânicos, como na Figura 8:

1. O magmatismo Permo-Triāssico distribui-se em vārias partes da ārea em estudo. Em particular, destaca-se o enxame de diques bāsicos de direção N-S no Territōrio Federal do Amapā, representados aqui pelas anālises de nọs $80,85,86$ e 96, com idades aparentes K/Ar entre 250 e 210 m.a. (Tabela 7). A presença destes extensos diques no Amapā, formando uma faixa com largura aproximada de $150 \mathrm{~km}$ por 250 km de comprimento, denuncia a existéncia de grandes linhas de fraqueza naquela época. Tais zonas de fraqueza, de direção aproximadamente $\mathrm{N}-\mathrm{S}$, parecem atingir a região do rio Itacaiunas (folhas SB 22 Araguaia) onde alguns resultados radiométricos assemelham-se aos constatados para a região do Amapà.

2. O vulcanismo iniciou-se também no Permo-Triāssico na região do bai火o e médio curso do rio Amazonas (Figura 8), na região do baixo curso do rio Aripuanã (folha SB 20 Purus), e na região do rio. Içana e alto rio Negro (folhas SA 19 Içá e SA 20 Manaus). Em outros tratos do Escudo das Guianas e notadamente no Suriname, datações K/Ar em diques de diabāsio indicam valores entre 240 e 200 m.a. (Priem,, 1968) demonstrando a amplitude regional do evento vulcâni co.

3. A segunda fase da reativação tectonomagmātica atuou desde o Jurāssico atē o Cretāceo inferior, parecendo ter ating do äreas mais centrais da Amazōnia (Figura 8). Constata se que as maiores concentraçoes de rochas com este padrão radiométrico localizam-se no Territōrio Federal de Rorai- 


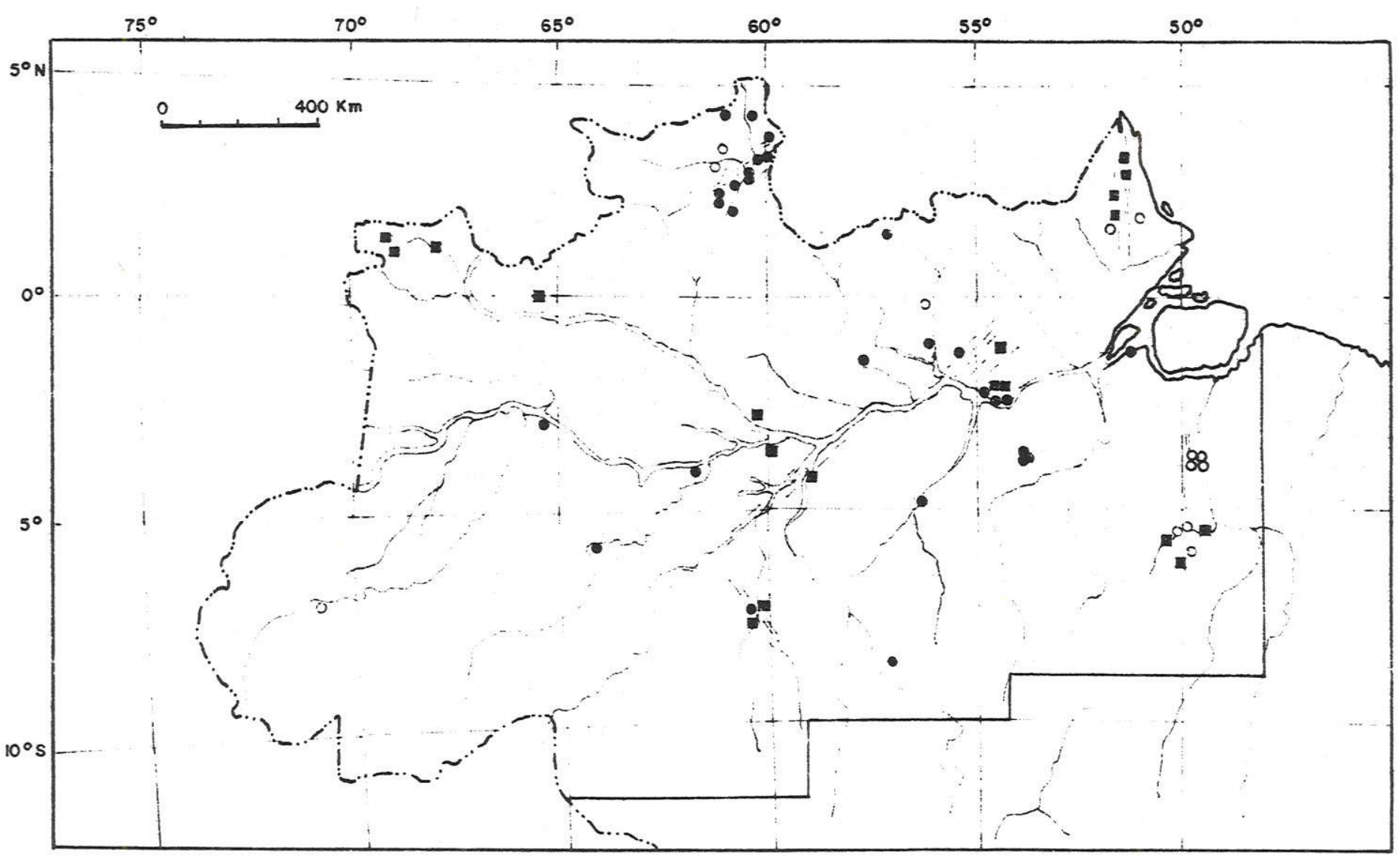

\section{LEGENDA (m. a.)}

- $200-120$

- 260-200

o $>300$

FIGURA 8 - DISTRIBUIÇÃO GECGRÁFICA DOS FOCOS MAGMÁTICOS BÁSICOS FANEROZÓICOS. 
ma, onde as rochas bāsicas com direção estrutural concor dante com o lineamento Takutu (NE-SW) demonstram a reati vação sofrida por esta zona de fraqueza após a consolida ção da plataforma Amazōnica. Magmatismo básico Juro-Cretāceo também é observado no baixo curso do rio Anazonas evidenciando inclusive reativação de zonas de fraqueza anteriores. 


\section{CAPITULO V}

\section{MAGMATISMO ALCALINO}

1. Generalidades

Nos Escudos Brasil Central e das Guianas são conhecidas diversas estruturas igneas circulares, ovais ou elipsoidais, de composição alcalina, ultrabāsico-alcalina e carbonatītica que têm sido objeto de vārios programas geocronolōgicos. As intrusões, tîpica atividade cratogēnica, acham-se encaixadas em rochas pré-Cambrianas, estando condi cionadas a parāclases profundas que habilitaram sua ascen săo para a crosta. Em termos geográficos, distribuem-se pre ferencialmente nas porções norte-oriental e centro-sul da àrea investigada.

As considerações a serem efetuadas no capĩt 10 têm por base os estudos petrográficos do projeto RADAMBRASIL. Na discussão dos eventos alcalinos serão levados em conta o padrão geocronológico e a situação geogrāfica das ocorrēncias.

No total, são dispoñiveis 29 determinações $\mathrm{Rb} / \mathrm{Sr}$ em rocha total e 7 anālises $\mathrm{K} / \mathrm{Ar}$, representadas respectivamente nos Apēndices 2 e $2 \mathrm{~A}$. Para um maciço alcalino (Canamã) dispõe-se de isōcrona verdadeira Rb/Sr em rocha to tal (Figura 9). A localização das amostras datadas acha- se definida na Figura 2. Cabe ainda frisar que nem todas as ocorrēncias alcalinas conhecidas da região Amazônica possuem datações, servindo o presente estudo de orientação para futuros trabalhos a respeito desta atividade.

De modo geral para as rochas intrusivas ri- 
cas em Rb, a anālise radiomētrica Rb/Sr convencional (assu mindo-se $\left.S r^{87} / \mathrm{Sr}^{86}=0,705\right)$ define a prōpria ēpoca da intrü são. Na falta de dados adicionais, o autor considerará as idades obtidas por este método como indicativas, no geral, de formação de rochas por serem os resultados praticamente independentes do valor assumido nos cálculos para a relação isotópica inicial. Duas amostras (nọs 148 e 151, Apêndice 2) não possuem disponīvel em sua publicação original (Priem et al., 1971) o valor do erro analitico de idade. Neste caso, o autor assumirā que as idades estão sujeitas a margem de erro admissível para o método radiométrico, da ordem de $5 \%$.

Com relação às anāilises K/Ar, a datação em rocha total e feldspatos potássicos, estes normalmente pertitizados, origina valores radiomētricos inferiores aos obtidos atravēs do método Rb/Sr. Tais resultados serão aqui interpretados como minimos. No caso de biotitas ( nọs 156 e 157), os valores são considerados próximos à época de formação da intrusiva, tendo em vista a boa retentivida de para argōnio destes minerais. Pelo exame do Apēndice $2 \mathrm{~A}$, evidencia-se que a amostra de nọ 157 tambēm não relatava na publicação original, (Priem et a1., op.cit.) o erro ana lîtico da idade. Aqui tambēm serā assumido que o erro não seria superior aos médios obtidos nas anālises do RADAMBRA SIL, inferiores a $5 \%$.

Os dados radiomētricos Rb/Sr e K/Ar permi tem distinguir dois conjuntos geocronológicos de rochas al calinas. 0 mais antigo, melhor definido, possui idades do pré-Cambriano superior, ao passo que o mais jovem, ainda pobremente caracterizado, acusa idades Mesozóicas.

Inūmeros autores têm estudado as rochas alcalinas devido à sua importância econômica. Trabalho discu tindo especificamente o magmatismo alcalino pré- Cambriano 
e Mesozóico na porção brasileira do Escudo das Guianas foi elaborado por Issler (1975a). Outras sīnteses que abordam o assunto são as de Amaral (1974), Issler (1975), Basei e Teixeira (1975), Montalvão (1976), Teixeira et al. (1976)e Issier (1977).

2. Caracterização Geocronológica da Atividade pré-Cambriana

Este conjunto de idade possui atē o presente 25 anälises $\mathrm{Rb} / \mathrm{Sr}$ e $6 \mathrm{~K} / \mathrm{Ar}$ (Tabelas 9 e 10). 0s resultados variam entre 1.800 e $930 \mathrm{~m}$. a. para o primeiro método radio métrico e entre 1.170 e $800 \mathrm{~m}$. a. para o segundo. Os dados analíticos das anālises Rb/Sr mostram-se de boa qualidade no geral, com algumas exceções, no caso das anālises : com quantidades desfavoráveis de estrôncio em relação ao rubīdio (nọs 136, 141, 144, 149, Apēndice 2). Tais resultados apresentam-se com erros elevados, não se considerando seus valores isolados como geologicamente significativos. Para os dados K/Ar, os erros analiticos são normais e o ünico valor mais elevado, da ordem de $5 \%$, e relativo à intrusão do Canamã (anālise nọ 156), não merece maior restrição interpretativa visto que a idade concorda com aquela do diagrama isocrônico da Figura 9, construído com os dados analïticos Rb/Sr de outras amostras da intrusão.

As ocorrências alcalinas prē-Cambrianas mais significativas estão situadas na porção oriental do Escudo das Guianas, condicionadas aos lineamentos Jari-Falsino e Tumucumaque (Figura 3). No Crāton do Guaporē, as intrusivas concentram-se na sua porção centro-ocidental, nas imediações do Domo do Sucunduri, e prōximo da borda sudoeste do Grupo Beneficente, onde condicionam-se à falha do Canamã (Figura 3).

A idade Rb/Sr convencional mais antiga que 
TABELA 9 - RESULTADOS Rb/SP PARA O MAGMATISMO ALCALINO PRE-CAMBRIANO

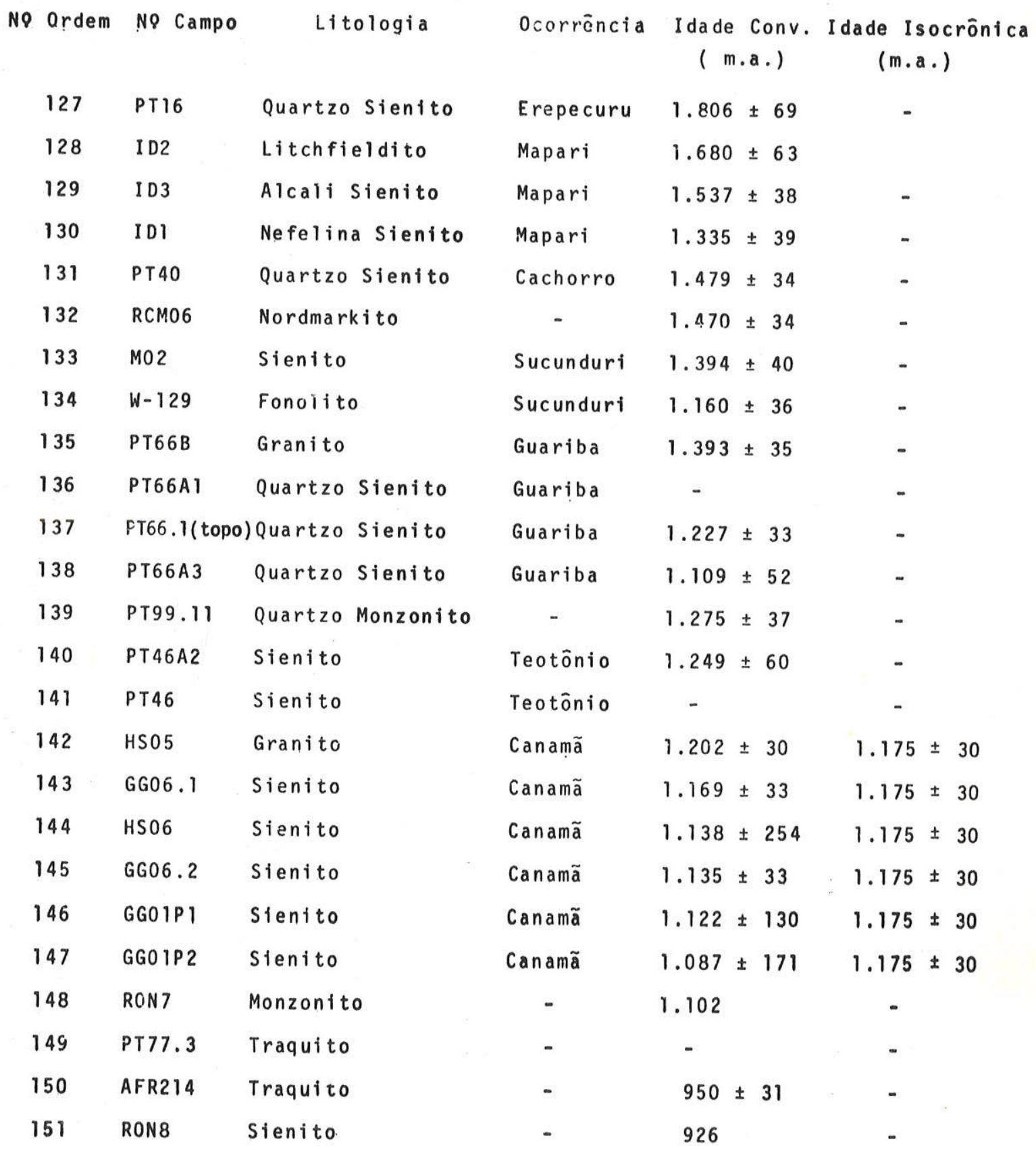

TABELA 10 - RESULTADOS K/AR PARA O MAGMATISMO ALCALINO PRE-CAMBRIANO

$\begin{array}{clclll}\text { No Ordem } & \text { No Campo } & \text { Ocorrência } & \text { Litologia } & \text { Mineral } & \begin{array}{c}\text { Idade } \\ (\mathrm{m.a.})\end{array} \\ 156 & \text { GG01P2 } & \text { Canamã } & \text { Sienito } & \text { Biotita } & 1.169 \pm 57 \\ 157 & \text { RON7 } & - & \text { Monzonito } & \text { Biotita } & 1.035 \\ 158 & \text { PT14II } & \text { Mutum } & \text { Nefelina Sientto } & \text { Ortociāsio } & 1.026 \pm 28 \\ 159 & \text { RR78 } & - & \text { Sienito } & \text { RT } & 924 \pm 10 \\ 160 & \text { PT77.3 } & - & \text { Traquito } & \text { RT } & 872 \pm 10 \\ 161 & \text { PT09 } & - & \text { Monzonito } & \text { Ortociāsto } & 803 \pm 6\end{array}$


se dispõe para rochas alcalinas na ārea investigada referese ao maciço Erepecuru, com $1.806 \pm 69$ m.a. (amostra nọ 127, Tabela 9), aqui interpretada como a ēpoca da formação da in trusiva. Define-se deste modo, uma atividade cratogēnica na provīncia Amazônia Central, jā no inīcio do pré - Cambriano superior, em região afetada pelo lineamento Cachorro. Tal resultado implica em se admitir,para esta zona de fraqueza, atividade vulcânica de caräter alcalino a partir da fase pōs-tectōnica principal do ciclo orogênico Transamazônico.o sienito Erepecuru, descrito por 01 iveira et al. (1975), situa-se na extremidade sudeste da folha NA21ZA, próximo da margem direita do rio que the deu o nome.Dois corpos ígneos circulares foram definidos, sendo intrusivos nas rochas metamōrficas prē-Cambrianas da provīncia Amazōnia Central (Fi gura 3 ).

Para as alcalinas Mapari foram obtidas trés idades Rb/Sr convencionais (nọs 128, 129 e 130; Tabela 9), com resultados discordantes, variando entre 1.680 e 1.330 m.a. A amostra em que a idade aparente mais jovem foi obti da (nọ 130) acusou intensa alteração intempérica ao estudo micropetrográfico; por esta razão, o autor considerarā os valores mais antigos como mais representativos do evento al calino. Para uma conclusão definitiva sobre a ēpoca do "emplacement" deste conjunto de intrusivas seria necessārio maior nūmero de resultados, e seu tratamento atravēs de dia grama isocrōnico. Na opinião do autor, os dois valores radiométricos aqui assumidos como vālidos indicam atividade magmātica cratōnica recorrente, com idades "reais" de 1.680 e $1.540 \mathrm{~m} . \mathrm{a}$.. 0 exame da Figura 3 permite verificar que as intrusivas ocorrem na zona limitrofe entre o cinturão Maroni-Itacaiunas e a província Amazônia Central, mais precisamente nos cruzamentos dos lineamentos Tumucumaque e Jari-Falsino. 
Maraconaī e Apupariū (Lima et al., 1974), concentram-se nos limites das folhas SA 21 Santarēm, SA 22 Belém e NA/NB 22 Macapā. Dispõem-se grosseiramente numa faixa quase NE-SW, desde a margem esquerda do médio curso do rio Maicuru até a margem esquerda do médio curso do rio Mapari. As alcalinas apresentam-se isoladas, intrudindo as rochas granito gnāissicas do embasamento e tambēm os metassedimentos do Grupo Vila Nova. Anālises petrogrāficas efetuadas pelo RADAMBRASIL em rochas da intrusão de Mapari evidenciaram nefe lina-sienitos, litchfielditos e alcali-sienitos. Os demais corpos encontram-se capeados por espesso manto laterítico, dificultando as amostragens. A filiação alcalina destas rochas foi definida atravēs de anālises quīmicas e espectro gräficas do laterito.

Caracterizando o magmatismo alcalino no Escudo das Guianas em ēpoca posterior às alcalinas Mapari tem se duas idades Rb/Sr convencionais (nos 131 e 132; Tabela 9), a primeira delas representativa do maciço intrusivo Cachorro. 0s dois resultados, próximos a $1.480 \mathrm{~m} . \mathrm{a}$. , exibem elevadas relações isotöpicas $S r^{87} / S r^{86}$ (Apēndice 2), o que thes confere ótima confiabilidade analîtica.

A presença de rochas alcalinas datadas em cer ca de 1.480 m.a., ao longo do lineamento Cachorro, reforçá a hipótese proposta no capītulo IV quanto ao relacionamento entre o magmatismo alcalino e bāsico. Com efeito, as rochas bāsicas a partir de $1.550 \mathrm{~m}$.a. acusam enriquecimento sugestivo em potāssio, como será visto mais adiante. 0 sistema de fraqueza referido acima, que secciona grandes tratos do Escudo das Guianas, atuaria neste contexto como conduto para a ascensão vulcānica bāsica e/ou alcalina (Figura 4).

0 sienito Cachorro (01iveira et al., 1975) 음 corre ao sul da folha NA2IYD quase no limite com a folha SA 21 Santarém, na margem esquerda do rio que the deu o nome. 
Constitui uma serra alongada no sentido NW-SE, sendo intru sivo no embasamento da provīncia Amazônia Central.

Outros corpos associam-se à intrusiva Ca-chorro, como por exemplo aquele cuja idade mostrou-se concordante (no 132). Além disso, Araujo et al. (1976), ao estudarem a folha SA 21 Santarēm, correlacionam vārios outros corpos, situados entre os rios Nhamundá e Mapuera,com aquela intrusão.

A intrusiva alcalina do Domo do Sucunduri $\bar{e}$, até o momento, o registro mais antigo deste tipo de at $\underline{i}$ vidade no Cráton do Guaporē, estando datada pelo mētodo $\mathrm{Rb} / \mathrm{Sr}$ convencional em cerca de $1.400 \mathrm{~m} . \mathrm{a}$. (anāilise nọ 133, Tabela 9). Sua elevada relação isotōpica $S r^{87} / \mathrm{Sr}^{86}$ (ver Apēndice 2) dá confiabilidade analītica ao resultado, interpretado çomo representativo da formação da intrusiva.0u tra determinação radiomētrica Rb/Sr convencional em rocha efusiva da mesma estrutura ( $n$ ọ 134) indicou cerca de 1.160 m.a. 0 resultado demonstra que o magmatismo alcalino do Domo do Sucunduri foi diferenciado e permaneceu ativo por longo perīodo de tempo. 0 vomo do Sucunduri é uma estrutura anōmala em relação às feições morfolōgicas do Escudo Brasil Central situada quase inteiramente nos domīnios da folha SC 21 Juruena, e possuindo area de $700 \mathrm{~km}^{2}$ (Figura 3). Iwanuch (1976) reporta a ocorrência de rochas alcali nas em vārios locais da estrutura, na forma de "plugs", "necks", diques e pequenos derrames. Constata-se para o magmatismo ampla variedade litológica, sendo encontrados nefelina sienitos, sienitos, microsienitos, tonalitos e traquitos. Estas rochas intrudem as vulcānicas ācidas Teles Pires, bem como os sedimentos prē-Cambrianos do Grupo Beneficente.

A intrusiva Guariba (Leal et a1., 1974) estā representada por quatro datações $\mathrm{Rb} / \mathrm{Sr}$ convencionais 
(nos 135 a 138, Tabela 9). Os dados analiticos foram tenta tivamente incluĩdos em diagrama isocrōnico, porēm a mā dis tribuição dos pontos no gräfico impossibilitou uma interpretação adequada em termos de isōcrona Rb/Sr. Os dados ra diomētricos Rb/Sr convencionais situam-se entre 1.390 e $1.100 \mathrm{~m} . \mathrm{a}$. sugerindo que tal intrusão associa-se temporalmente com as do Domo do Sucunduri. Tal hipōtese è reforçada pela proximidade geogräfica das duas ocorrēncias (Figura 4), ambas situadas na borda noroeste-sul do Grupo Beneficente. A intrusiva Guariba sustenta um conjunto de serras localizadas à margem direita do rio Guariba, quase na confluência com o rio Aripuanã. Litologicamente predomi nam os sienitos apesar de ocorrerem tambēm rochas granīticas. 0 maciço é intrusivo nas rochas prē-Cambrianas do embasamento do cinturão mōvel Rio Negro-Juruena.

Idades Rb/Sr convencionais para ocorrências alcalinas pré-Cambrianas na porção sul-ocidental da Amazônia (Figura 2) foram obtidas para a intrusão do Teotônio (nọs 140 e 141) e para um quartzo monzonito que aflora na bacia dos rios Ciriquiqui e Curuquetê (anālise nọ 139). As idades são concordantes, fixando a ēpoca de cerca $1.250 \mathrm{~m}$. a. para a atividade alcalina na região. A alcalina do Teotônio (Leal et al., op.cit.), situa-se na cachoeira homônima no rio Madeira, folha SC20VB. A atividade ígnea, cons tituída por sienitos, monzogranitos e granitos, é intrusiva no embasamento cristalino do cinturão móvel Rondoniano.

Magmatismo alcalino na porção centro-sul da região é representado pela intrusão do Canamã, datada em isōcrona (Figura 9) em $1.175 \pm 30 \mathrm{~m} . \mathrm{a} \cdot(2 \sigma)$, com relação inicial $\mathrm{Sr}^{87} / \mathrm{Sr}^{86}=0,704 \pm 0,001$, o que sugere que o magma alcalino näo sofreu processos de contaminação crustal. A ịsócrona verdadeira Rb/Sr em rocha total define claramen te a ēpoca da formação da intrusão do Canamã. Em adição, foi realizada uma datação K/Ar em biotita (anālise nọ 156, 


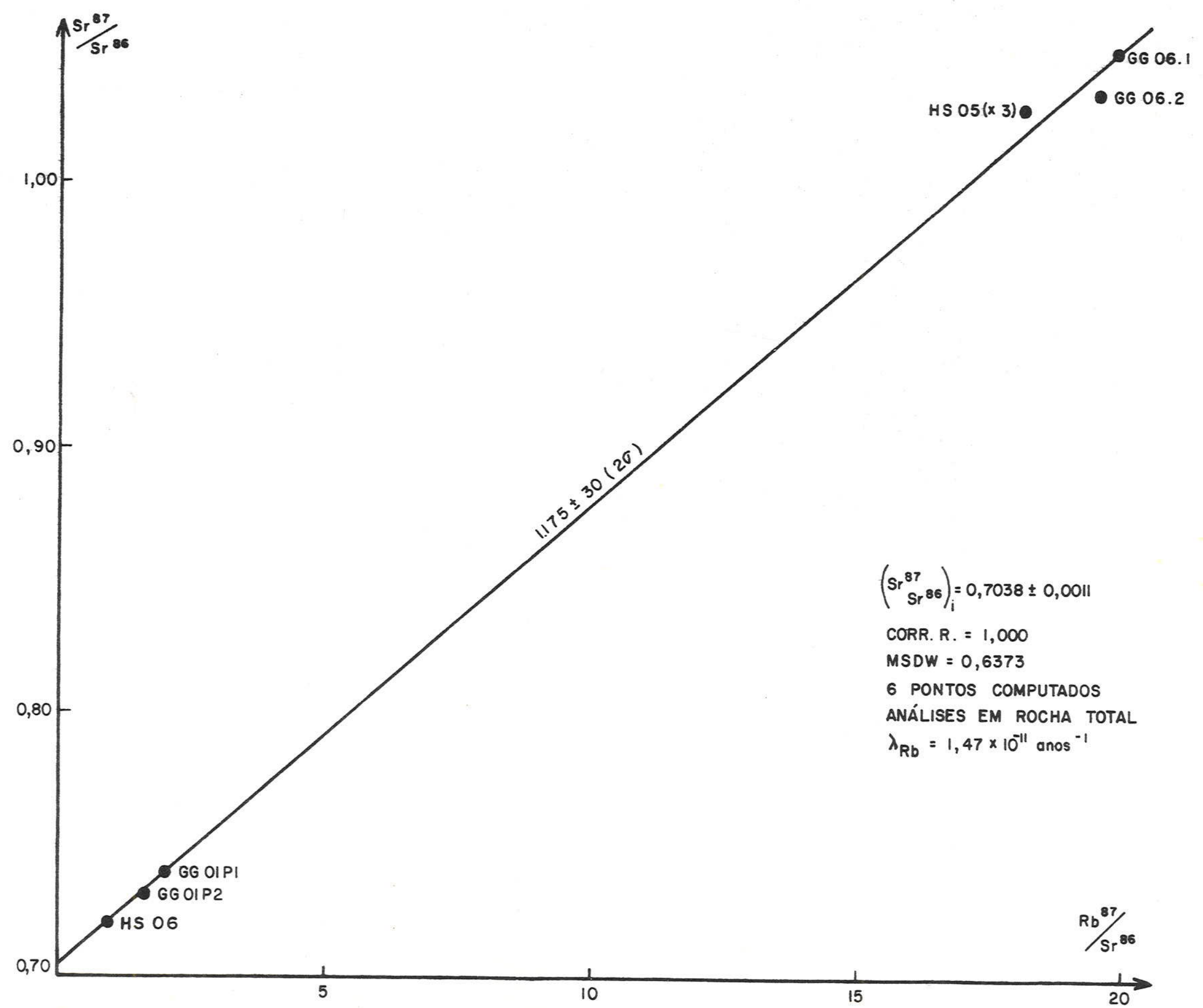

FIGURA 9 - DIAGRAMA ISOCRÔNICO RD/ST DO SIENITO CANAMĀ 
Tabela 10), com resultado concordante. A alcalina Canamã (Silva, G.H. et al., 1974), mais precisamente um nordmarkito, acha-se situada na folha SC21YA. Possui forma ovalada, estando condicionada à extensa falha de direção NW-SE. 0 maciço é intrusivo em rochas prē-Cambrianas do embasamento do cinturão mövel Rio Negro-Juruena, possuindo a mesma orientação estrutural deste.

Atividade alcalina associada, na opinião do autor, à ēpoca da intrusiva Canamã é constatada na parte norte da bacia Amazônica. Trata-se do sienito Mutum, para - qual uma determinação radiomētrica K/Ar ( nọ 158, Tabela 10) indicou vălor pröximo a $1.000 \mathrm{~m}$.a.. O resultado é aqui interpretado como mínimo para o corpo, em face do mineral pouco favorável (ortociásio) empregado na análise radiomé trica. 0 sienito Mutum (Montalvão et al., 1975) ocorre no extremo setentrional da folha NA21YB, na divisa territorial com a Repūblica da Guiana. o corpo ígneo feldspatóidico é intrusivo nas rochas do embasamento da provīncia Amazōnia Central.

Os demais resultados radiométricos para atividades alcalinas prë-Cambrianas no Escudo das Guianas e Crāton do Guaporē representam ocorrēncias de menor expres são.

No caso do Escudo das Guianas, conhecem- se apenas duas determinações radiométricas K/Ar, respectivamen te para um sienito localizado na parte norte do Territōrio Federal de Roraima (anālise nọ 159) e um monzonito da bacia do alto rio Uatumã ( $n 0$ 161), com idades mínimas de 920 e de $800 \mathrm{~m} . \mathrm{a}$. (Tabela 10 , Apêndice 2A). 0 monzonito situa se em ārea afetada pelo lineamento Cachorro e sua idade é concordante com a de duas rochas bāsicas datadas na região ( nọs 65 e 66, Apēndice 1). Uma destas acusa teor de potás sio próximo a $2,5 \%$, o que parece demonstrar o relacionamen- 
to genētico dos magmas bāsico e alcalino, na ēpoca de 850 m.a. .

Para o Crāton do Guaporē, dispõe-se de qua tro idades Rb/Sr convencionais ( $n$ os de 148 a 151, Tabela 9) e duas K/Ar ( $n$ ọs 157 e 160, Tabela 10). As anālises de ncs 148, 151 e 157, obtidas por Priem et a1. (1971), referem-se ao complexo estanīfero de Oriente no Territōrio Fe deral de Rondōnia e representam diferenciações do magma granitico daquela intrusiva. Aqueles autores, trabalhando os dados analiticos Rb/Sr disponīveis para aquele maciço e outros semelhantes no Territōrio, determinaram idade isocrōnica Rb/Sr de referência igual a $980 \pm 20 \mathrm{~m} . \mathrm{a}$., interpretando-a como ēpoca principal da atividade cratogêni ca. Por outro lado, um traquito da porção noroeste de foTha SC20VC apresentou idade minima K/Ar em torno de 870 m.a. (nọ 160, Tabela 10), sugerindo uma associação magmātica com os granitos anorogēnicos. Sua idade convencional $\mathrm{Rb} / \mathrm{Sr}$, assumindo-se $\left(\mathrm{Sr}^{87} / \mathrm{Sr} \mathrm{r}^{86}\right)_{i}=0,705, \overline{\mathrm{e}}$ incompatīvel com a situação geológica local, podendo ser explicada por uma razão inicial real muito mais elevada, ou por excesso do Sr radiogênico em minerais secundārios tais como a can crinita. Outra rocha geograficamente próxima, de idêntica composição, apresentou idade Rb/Sr convencional de cerca de $950 \mathrm{m.a}$. (nọ 150, Tabela 9), reforçando a hipōtese ac $\underline{i}$ ma exposta.

3. Caracterização Geocronológica da Atividade Mesozóica

São escassos os resultados radiométricos para rochas alcalinas Mesozōicas na plataforma Amazōnica. Dispõe-se de quatro determinações Rb/Sr convencionais (Ta bela 11) e apenas uma idade aparente K/Ar.

Para o corpo alcalino República (Barros et 
al., 1977) foram obtidas duas anālises Rb/Sr e uma K/Ar (no 162). A rocha traquítica datada (anälise no 153) indi cou idade Rb/Sr mais jovem que o quartzo sienito (anālise no 152), o que è corroborado pelos dados de campo que definem a primeira rocha como intrusiva na segunda. Infelizmente os teores de rubídio e eströncio totais do quartzo sieni to (Apêndice 2) mosträram-se pouco favorāveis para uma data çăo convencional. Em adição, a anälise radiomëtrica $\mathrm{K} / \mathrm{Ar}$ em rocha total ( $n$ o 162, Apēndice $2 A$ ) definiu uma idade em torno de $240 \mathrm{~m}$. a. para a intrusiva República. Cumpre ressal tar que alguns resultados semelhantes para rochas bāsicas foram constatados em outras āreas da Amazönia (nọs de 81 a 84, Apēndice 1). A intrusäo ïgnea situa-se no extremo sulocidental da Amazónia (Figura 2), ocorrendo na ārea da rede de drenagem dos igarapēs Capanauá, Indio, Coronel e Repūbli ca (folha SBI8ZC). Litologicamente a ocorrência é representada por quartzo sienitos cortados por diques de quartzo queratófiros, felsitos e traquitos. As exposições de rocha possuem ārea restrita, apresentando-se em forma de diques que cortam os quartzitos e metassiltitos da Formaçăo Formosa.
\end{abstract}

TABELA 11

RESULTADOS Rb/Sr PARA O MAGMATISMO ALCALINO MESOZOICO

$\begin{array}{ccccc}\text { Nọ Orden } & \text { Nọ Campo Litologia } & \text { Ocorrēncia } & \begin{array}{c}\text { Idade Conv. } \\ (\mathrm{m} . \mathrm{a} .)\end{array} \\ 152 & \text { CAPO9Al } & \text { Quartzo Sienito } & \text { Repūblica } & 210 \pm 96 \\ 153 & \text { CAPO8AT } & \text { Quartzo Traquito } & \text { Repūblica } & 162 \pm 51 \\ 154 & 1156-130 & \text { Nefelina Sienito } & \text { Catrimani } & 102 \pm 6 \\ 155 & 1156-130 & \text { Nefelina Sienito } & \text { Catrimani } & 95 \pm 8\end{array}$


As duas datações restantes (nọs 154 e 155 , Tabela 11) referem-se à intrusão de Catrimani, no Território Federal de Roraima. O sienito foi originalmente estuda do por Santos e Salas (1974) que relatam sua presença no interfiūvio Catrimani-Ägua Branca do Univi, e no morro da Agua Preta. A rocha intrusiva possui pequena dimensäo, sen do cortada por fonolitos. As idades Rb/Sr convencionais são concordantes em cerca de $100 \mathrm{~m}$.a.. Resultados semelhan tes foram obtidos para as lavas bāsicas da Formação Apoteri que ocorrem em ārea prōxima, no Graben do Takutu. A pre sença destas rochas bāsicas e alcalinas condicionadas ao lineamento Takutu (Figura 3 ) demonstra que esta zona de fraqueza manteve-se ativa até o cretáceo. 
CAPITULO VI

\section{CONSIDERAÇOES FINAIS}

O estudo geocronolögico das rochas bäsicas na regiăo Amazōnica possibilitou definir, atē o momento, quatro conjuntos radiomëtricos no prē-Cambriano (2.000-1.550 m.a. ; 1.500-1.300 m.a.; 1.250-1.050 m.a.; 1.050-850 m.a.) e dois no Fanerozóico (500-300 m.a.; 260-120 m.a.). Com exceção do mais antigo, provavelınente o de caracterização menos adequada, e que cobre um intervalo de tempo muito amplo, todos os demais possuem duraçăo da ordem de $200 \mathrm{~m}$.a., compatível com - que se presume ser a duraçăo aproximada de um padrão estăvel de movimentos convectivos no manto superior. Do ponto de vista da significaçäo geotectōnica, os conjuntos prē-Cambria nos, bem como aquele eo-Paleozöico diferenciam-se do agrupamento mais jovem por estarem associados, na opiniäu do autor, à evoluçăo geolögica das provincias de idade da plataforma Amazónica. Fenomerios alcalinos cratogénicos, definidos atra vës de razoāvel nümero de idades radiométricas, relacionam se ao vulcanismo bäsico notadamente no intervalo de lempo 1.500-1.100 m.a., e possuem as principais ocorrëncias nas porçues oriental do Escudo das Guianas e centro-sul do cráton do Guaporë.

Os vulcanismos alcalino e bäsico prē-Cambrianos encontram-se condicionadcs às principais zonas de fraque za que seccioriami toda a plataforma Amazōnica. Como um todo, caracterizam um prolongado estägio de estabilização para esta unidade geotectōnica, a qual comportou-se como ärea intei ramente rigida somente a partir do ciclo Brasiliano. Constataçäo interessante é a falta de idades antigas, até o momento, para o magmatismo bāsico e alcalino nas āreas abrangidas pelas provincias geocronológico-estruturais mais jovens (Rio Negro-Juruena e Rondoniana), o que vem reforçar a hipótese 
de uma evolução progressiva da Plataforma, durante o préCambriano superior, no sentido nordeste-sudoeste. As princi pais zonas de fraqueza ativas durante todo o período de tempo mencionado possuem direções NE-S'N e NW-SE.

0 conjunto Fanerozöico apresenta a maioria das idades no Mesozóico, sendo aqui inierpretado como refle xo, em ārea cratonizada, de processos ligarios aos fenómenos da deriva continental e formação do oceano Atiāntico. Seus registros distribuem-se por toda a Amazōnia, havendo porém maior frequência na sua porção norte-oriental, onde condicionam-se a sistemas de fraqueza NS e NNE. São ainda escas sos os registros de rochas alcalinas temporalmente associadas ä reativaçäo na àrea investigada.

1. Significação tectönica do vulcanismo bāsico e alcalino de idade prë-Cambriana

0 desenvolvimento dos sucessivos cinturões mōveis definidos para a região Amazōnica abrangeu longo período de tempo, durante o qual ocorreram fenōmenos magmáticos e sedimentares, estes ültimos representando os respecti vos molassóides daqueles eventos geodinämicos. Dentro deste contexto, os eventos básicos são interpretados como mağmatismo associado aos eventos terminais daqueles cinturöes me tamörficos e/ou magmatismo reflexo do seu desenvolvimento, sobre āreas adjacentes jā cratonizadas.

Com base nos dados geocronolōgicos disponiveis, è possível afirmar que a estabilizaçăo tectōnica da plataforma Amazōnica teria ocorrido somente com o térilino dos fenómenos tectonomagmāticos da faixa mövel Rondoniana, há cerca de $1.000 \mathrm{~m} . \mathrm{a}$.. No ciclo Brasiliano, por ocasião da evoluçäo do geossinclīneo Paraguai-Araguaia, a plataforma jā teria se comportado como unidade estāvel. 
As determinações radiomëtricas mais definiram uma concentração de idades entre 1.950 e 1.850 m.a., afetando a província Amazónia Central, e o evento é aqui interpretado como magmatismo terminal do ciclo orogēni co Transamazönico, ou seja, o estägio evolutivo final do cinturão mövel Maroni-Itacaiunas. Relacionadas à fase de transição deste "mobile belt" apareceram as rochas vulcānicas ācidas das formações surumu e Iricoumë, recentemente es tudadas por Basei (1977). A elas associadas, ocorrem depósitos sedimentares, como os cio chamado Grupo Roraima, por vezes intrudidos por magmäticas bäsicas. Definindo a época de cratonização em relação ao ciclo Transamazōnico tem-se o sienito Erepecuru, datado em 1.800 m.a..

Posteriormente, novas atividades alcalinas manifestar-se-iam na porção estabilizada, tendo-se como exemplo as intrusivas Mapari (1.680-1.530 m.a.). Rochas bāsicas com idades semelhantes, no Escudo das Guianas, sugerem um relacionamento entre os dois episödios, e, em conjunto com o vulcanismo äcido "Uatumä-Iriri", caracterizarianı provavelmente um reflexo, nas àreas estäveis da mesma província Amazōnia Central, do desenvolvimento do cinturão móvel Rio Negro-Juruena (1.700-1.400 m.a.).

0 segundo conjunto significativo de idades para rochas básicas, caracterizado neste trabalho, indica uma concentração de valores entre 1.500 e $1.300 \mathrm{~m} . \mathrm{a}$., inter valo temporalmente associado com o final dos processos meta mörficos do cinturão Rio Negro-Juruena. De modo anālogo ao constatado para as rochas bäsicas Transamazōnicas, este epi sōdio mais jovem possui atividade alcalina associada, a qual afeta āreas jä cratonizadas. Säo exemplos as intrusões do Cachorro (1.480 m.a.) e Sucunduri (1.400 m.a.). Depósitos sedimentares e vulcanismo äcido relacionados ao mesmo evento geodinâmico acham-se preservados em alguns tratos dos Es cudos Brasil Central e das Guianas. Constituem exemplos as vulcānicas ácidas dos rios Teles Pires, Juruena e Roosevelt 
(estudadas por Basei, op.cit.), os sedimentos da Formação Prosperança, do Grupo Beneficente, da Chapada dos Dardanelos e das Serras da Providência e Três Irmãos.

Recorrência de magmatismo bāsico è constata da, no período $1.250-1.050 \mathrm{~m} . \mathrm{a}$., pelas rochas de tal idade condicionadas geograficamente às grandes zonas de fraqueza da Amazonia. A característica das ocorrēncias sugere que o fenömeno īgneo seja um provävel reflexo, em ārea adjacente jā estāvel, do desenvolvimento do cinturão móvel Rondoniano (1.400-1.000 m.a.). Atividade alcalina associa-se ao vulcanismo bāsico, como demonstram as intrusões do Teotónio e Guâriba $(1.250 \mathrm{~m} . \mathrm{a}$.$) , Canamă (1.180 m.a.) e o fonol$ to do Domo do Sucunduri $(1.160 \mathrm{~m} . \mathrm{a}$.$) . A quantidade de ro-$ chas alcalinas com idades entre 1.500 e $1.150 \mathrm{~m}$.a. sugere que este tenha sido o período principal de sua formação, sendo até o momento difícil uma separaçăo em fases magmāti cas distintas. Os resultados radiomëtricos evidenciam ainda que no Escudo das Guianas o processo terminou antes que na porção sudoeste do Escudo Brasil Central, onde os valores são sistematicamente mais jovens que 1.400 m.a.. Merece ser ressaltada a ocorrência do assim chamado "evento tectonotermal Nickeriano", que atuou de maneira generaliza da na porção norte do Escudo das Guianas, e que acusa idades aparentes K/Ar entre 1.250 e 1.000 m.a., sendo portanto sincrōnico aos episódios ígneos básicos e alcalinos aqui descritos, e localizados predominantemente no Territó rio Federal de Rondōnia.

0 fenōmeno īgneo básico com idades entre 1.050 e $850 \mathrm{~m} . \mathrm{a}$., também preferencialmente situado na região do Territōrio Federal de Rondōnia, indica, na opinião do autor, o magmatismo terminal do evento geodinâmico Rondoniano (1.400-1.000 m.a.). 0 vulcanismo subsequente ao ci clo estaria representado pelas rochas efusivas äcidas da porção ocidental do Territōrio, na ärea de São Lourenço-Ma 
cisa (estudadas por Basei, op.cit.). Caracterizando provavelmente os molassöides do "mobile belt" tem-se os sedimentos da Serra dos Pacaās Novos e do vale do rio Mutum Parană. Atividade cratōnica tîpica da região è evidenciada pelos granitos estaníferos, datados em cerca de 980 m.a.. Estes corpos, por vezes, exibem diferenciaçöes litolögicas que podem chegar a monzonitos e sienitos.

2. Significação tectōnica do vulcanismo bāsico e alcalino de idade Fanerozöica

0 vulcanismo eo-Paleozóico, que possui poucos registros radiomëtricos atē o momento, distribui-se geo graficamente acompanhando a porção ocidental do geossinclïneo Paraguai-Araguaia, em seu setor norte. Na opinião do au tor, representa o vulcanismo final da orogênese Brasiliana. Não se conhecem, atē o presente, manifestaçōes alcalinas as sociadas à evoluçăo do geossinclīneo.

A partir do Permiano atē o Cretäceo instalou se na plataforma Amazōnica uma reativação tectonomagmātica cujos registros são encontrados em toda a ärea investigada. 0 fenōmeno caracterizou-se pela formação de Grabens e Horsts, Sedimentação espessa e Vulcanismo toleítico, nossuindo como exemplo notāvel o Graben do Takutu, situado no extremo nordeste do Territōrio Federal de Roraima e adentrando na Repüblica da Guiana.

0s resultados radiomētricos parecem sugerir a ocorréncia de dois ciclos vulcānicos durante a reativação (260-200 m.a.; 190-120 m.a.), não sendo possível, entretanto, definir uma situaçăo geogräfica preferencial para qualquer dos ciclos. 0 atual conhecimento geocronolögico sugere que os dois āpices vulcānicos atingiram praticamente toda a região investigada, inclusive com recorrēncia magmätica em 
algumas āreas.

A fase Permo-Triässica não encontra correspondēncia em outros tratos da plataforma Sul-Americana. A mais jovem, com idades entre o Jurässico e o cretäceo inferior, parece corresponder à reativação Wealdeniana de Almei da (1967); entretanto, para a regiào Amazōnica, somente algumas rochas alcalinas (República, Catrimani, Seis lagos) são constatadas, ao conträrio do que ocorre na porção suloriental daquela Plataforma.

Recorrências magmāticas ao longo de sistemas tectónicos são evidenciadas, como demonstraram Thomaz et a1. (1974), pelas datações obtidas no poço MA 1 PA (nọs 79, 83 e 121 ) onde os testemunhos inferiores (79 e 83) revelaram idades Permo-Triāssicas e o superior (121), Jurāssica superior. Esta hipötese é corroborada pela presença na fo1ha SB 20 purus de rochas bāsicas Permo-Triāssicas em ärea prōxima a afloramentos de rochas similares juro-cretäceas.

Admitindo-se que as etapas ativas do tectonismo coincidam com maior produção de vulcanismo, as datações poderiam indicar a evolução do processo pela observação dos picos do magmatismo no histograma da Figura 7 . Assim, para o perīodo Permo-Cretāceo ter-se-ia um āpice magmä tico há cerca de 210-200 m.a. ao passo que as ēpocas em tor no de 180-170 m.a., 150-140 m.a. e 130-120 m.a. seriam as mais ativas do ciclo mais jovem.

Cumpre ressaltar que o autor concorda com a hipōtese proposta por Thomaz et al. (op.cit.) que associaram temporalmente a fase vulcānica mais antiga à separação da América do Norte do conjunto Africa-Amërica do Sul e a mais jovem com a separação da Africa e Amērica do Sul ( jā no Jurāssico). 
3. Caracterização genética do vulcanismo bāsico

Algumas considerações a respeito da gēnese do magmatisnı bāsico prē-Cambriano podem ser efetuadas, con base nos teores de potássio obtidos.

A Figura 10 apresenta trēs histogramas de teores de potāssio, para rochas bäsicas, relativos aos conjuntos pré-Cambriano (vulcanismo anterior e posterior a 1.600 m.a.) e Fanerozōico (vulcanismo Permo-Cretāceo).

Apesar do vulcanismo mais antigo que 1.600 m.a. possuir até o momento poucos registros radiométricos, constata-se que os teores de potássio concentram-se entre 0,5 e $1 \%$ (Figura 10A), indicando que a fonte dos magmas pri mārios estaria situada em níveis elevados do manto superior. 0 histograma do vulcanismo datado entre 1.570 e 850 r.a. (F gura 10B), diferencia-se do primeiro pela ampla variaçâo dos teores, alēm de um enriquecimento genërico no potássio. 0s resultados gradam entre 0,1 e $4 \%$, havendo mesmo um caso isolado com cerca de $5,5 \%$. Seguramente, estas variedades ri cas em potássio, embora aqui classificadas genericamente co mo "basaltos" com base nas descriçoes petrogräficas regionais, representam rochas geoquimicamente diferenciadas, cuja classificação mais adequada poderia ser de andesitos, tra quitos ou mesmo riolitos.

0 āpice dos valores permanece entre 0.5 e $1 \%$, existindo porēm uma concentração de resultados entre 1 e $3 \%$, o que sugere uma associação genëtica das rochas bāsicas des ta idade com magmas alcalinos. Note-se que a delimitação do perīodo de tempo entre 1.550 e $1.150 \mathrm{~m}$. a. para o āpice da atividade alcalina na região Amazōnica aproxima-se da época representativa do conjunto bäsico portador de anomalia potāssica. Tal conjunto de rochas bäsicas poderia ter se originado a partir de magmas diferenciados, ou mesmo por assi- 
A: - hISTOGRAMA DOS TEORES DE POTÁSSIO PARA

ROCHAS BÁSICAS DATADAS ENTRE 2.000 e 1.600 ma.
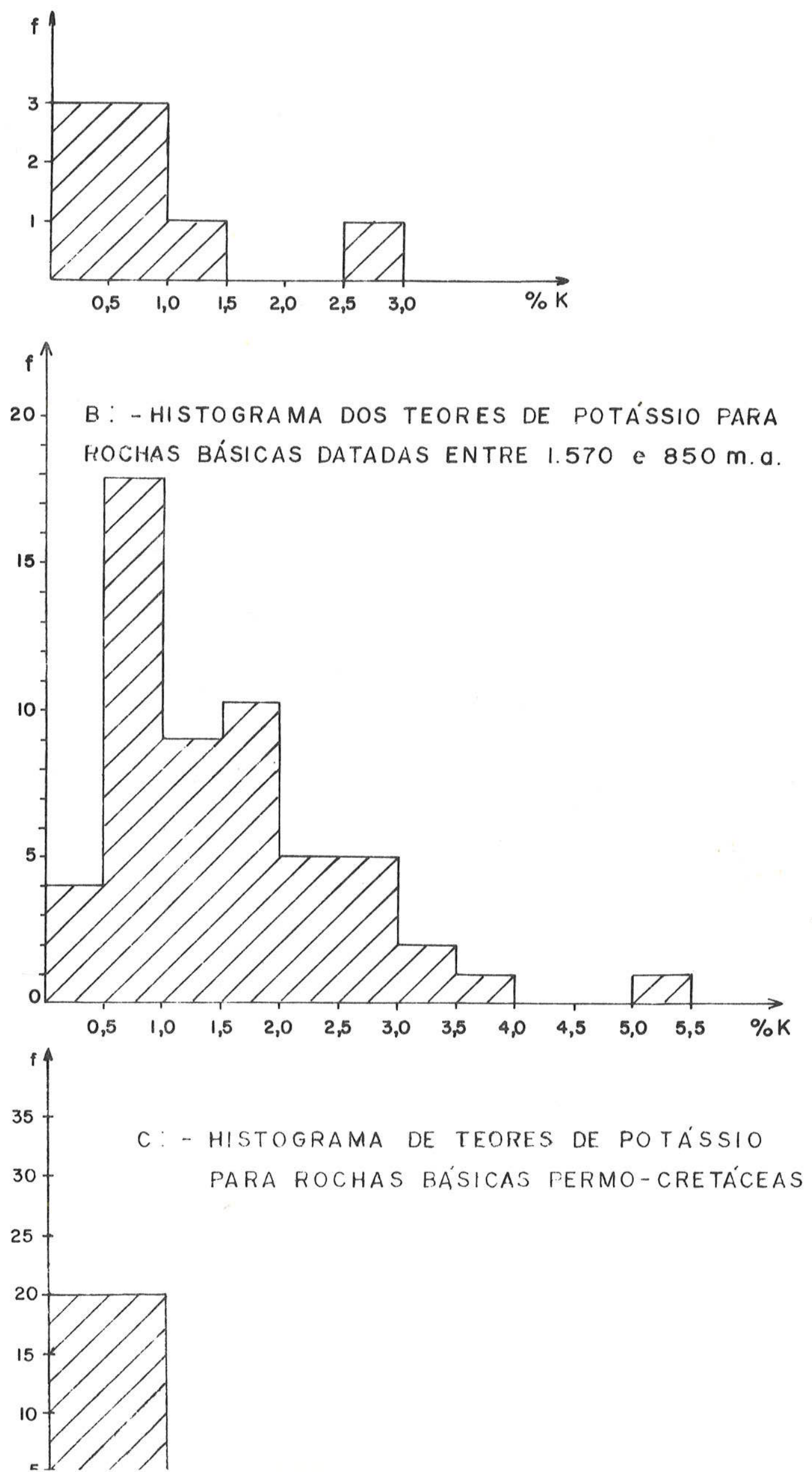
milação de material crustal mais rico em potāssio, quando de sua ascensão. As fontes primārias do magmatismo bāsico com idades entre 1.570 e $850 \mathrm{~m} . \mathrm{a}$. poderiam estar localizadas em nỉveis mais profundos do manto superior, em relação àquelas do vulcanismo mais antigo. Portanto, as evidências sugerem que o magmatismo pré-Cambriano se diferenciou geneticamente a partir de determinada ëpoca geolögica. Esta hipōtese assume validade geológica, na opinião do autor, em face do apreciável nümero de dados disponỉveis.

0 histograma do vulcanismo Permo- Cretáceo exibe média de teores de potássio abaixo de 1\% (Figura 10C). observam-se seis resultados acima da mëdia, porém a maioria dos teores concentra-se entre 0,5 e $1 \%$, sugerindo que o evento bāsico é primärio, não possui relacionamento com magmas alcalinos, e suas fontes são relativamente pouco pro fundas, no manto superior, do mesmo modo que as rochas basāiticas antigas.

4. Importāncia tectōnica dos lineamentos regionais da Amazōnia

Os vulcanismos bāsico e alcalino condicionam se claramente a sistemas de fraqueza regionais que seccio nam extensos tratos dos Escudos Brasil Central e das Guianas. Os principais lineamentos possuem direções regionais NE-SW, NW-SE, N-S e NNE-SSW, havendo evidências de reativações sucessivas e prolongada atividade ígnea na maioria deles. 0 melhor exemplo parece ser o grande lineamento Cachor ro, onde os diversos focos magmäticos datados incluem-se em todos os episódios vulcānicos discutidos no texto. Outro exemplo característico de recorrência de atividades magmāti cas acha-se definido para a folha SB 21 Tapajōs, onde as ro chas estäo condicionadas a sistema de fraqueza paralelo ao 1 ineamento Tapajōs, tal como aparece na Figura 4. 
As estruturas relativas aos vulcanismos bäs co e alcalino pré-Cambrianos associam-se aos lineamentos Má raiuiā, Melo Nunes, Cachorro, Jari-Falsino, Tapajōs, Abacaxis, Canamă, e outros menores de direções preferenciais NESW e NW-SE. Com o desenvolvimento do cinturäo mövel Rio Negro-Juruena (1.700-1.400 m.a.), houve intensa atividade ỉgnea bāsica e alcalina sincrōnica, principalmente nos domí nios da provĩncia Amazonia Central. Quando da evolução do cinturäo móvel Rondoniano (1.400-1.000 m.a.), ocorreu nova pulsação magmätica reflexa nas principais zonas de fraqueza das āreas jä cratonizadas, havendo recorrēncia dos fenômenos magmäticos nas provincias Amazōnia Central e Maroni-Ita caiunas, e manifestação na recëm-cratonizada faixa dobrada Rio Negro-Juruena.

0s "trends" estruturais das rochas bäsicas Fanerozóicas são generalizadamente N-S e NNE-SSW. A Figura 11 apresenta as direções principais de diques bäsicos e lineações aqui assumidas como ativas durante as reativações Permo-Cretāceas. E evidente que faltam dados estruturais pa ra uma melhor caracterização gräfica, entretanto o esboço poderā servir de base para futuros trabalhos a respeito do condicionamento estrutural do vulcanismo. As mais expressivas zonas de fraqueza relacionadas a estas reativações situam-se na parte norte da ārea estudada, desde o Territōrio Federal do Amapá atē o de Roraima. Os sistemas predominante mente $\mathrm{N}-\mathrm{S}$ parecem ser os principais condutos do vulcanismo fissural básico, cujas exposições mais representativas acham-se preservadas na parte norte-oriental da plataforma Amazōnica, configurando o lineamento Cassiporé. Entretanto, em vārias regiões, as direçöes infletem para NNE-SSW, NE-SW e NNW-SSE. E o caso da região de Monte Alegre (folha SA 21 Santarēm) onde o enxame de diques orienta-se segundo NE-SW, talvez condicionado ao lineamento Tapajós (situado ao sul do rio Amazonas) e/ou ao lineamento Jari-Falsino, que afeta as unidades estratigräficas da porção central do Territörio 


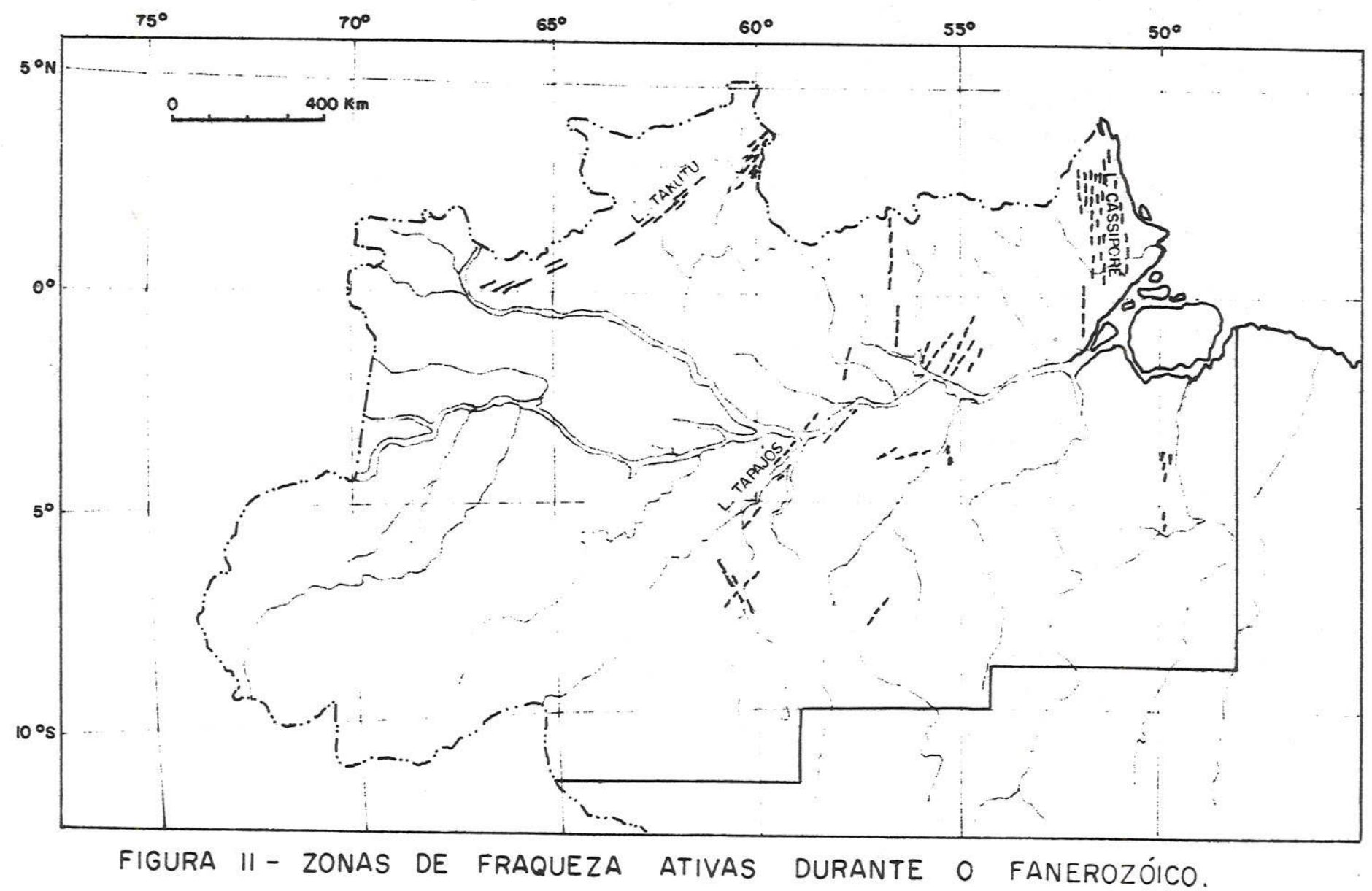


do Amapá. Outro exemplo significativo é o condicionamento estrutural (NE-SW) das lavas Mesozöicas do Graben do Takutu, as quais acompanham a direção do lineamento homōnimo no Ter ritōrio Federal de Roraima.

Destaque-se ainda que as tendēncias estruturais genéricas do vulcanismo Fanerozōico diferem daqueles observados para o vulcanismo prē-Cambriano, o que indica im portantes mudanças geodinämicas na crosta continental. 
AGRADECIMENTOS

A realização deste trabalho tornou-se possível graças às colaborações prestadas direta e indiretamente por vārias pessoas e em especial pelo projeto RADAMBRASIL.

Inicialmente o autor deseja consignar ao seu orientador Professor Doutor Umberto Giuseppe Cordani, Diretor do Centro de Pesquisas Geocronolōgicas da Universi dade de Säo Paulo, seus sinceros agradecimentos pelas sugestões durante a elaboração da tese e pelo incansāvel estỉmulo recebido. Os agradecimentos são extensivos ao Professor Doutor Koji Kawashita pelo apoio cientifico e laboratorial durante a execução do trabalho.

0 autor agradece aos colegas do RADAMBRASIL, na pessoa do ex-Diretor da Divisão de Geologia (DIGEO), geō logo Guilherme Galeão da Silva, pelo acesso às informações geolōgicas, bem como ao geōlogo Roberto Silva Issler, pelas discussões mantidas, indispensäveis para a elaboração desta sintese. Cumpre ressaltar a colaboração valiosa da equipe de petrografia do Projeto, na ēpoca formada pelos geólogos Jaime Franklin Vidal Araujo, Roberto Dall'Agnol, Ana Maria Dreher e Abel Salles Abreu, que auxiliou expressivamente a interpretação geocronolōgica.

Em especial, ao ex-colega do Projeto, hoje Professor Miguel Angelo Stipp Basei que coordenou os traba lhos geocronolögicos do autor quando do seu inicio profissional, e ao geólogo Colombo Celso Gaeta Tassinari, colega geocronólogo do Projeto, pela colaboração decisiva a partir de 1976, o autor manifesta sua gratidão.

Agradecimentos tambëm são devidos aos funcio nārios do CPGeo, a saber: Cläudio Comerlatti, clāudio dos 
Santos, Francisco E. Saracchini, Helen Sonoki, Ivone Sonoki, Jorge Gouveia de Almeida, Josē Elmano Gouveia, Josē Roberto Medeiros, Key Sato, Lourdes Marques, Margarida Martins e Miriam Amorim, bem como à Srta. Tieca Saito, esta pelo auxîlio nas anālises de fluorescēncia de raios $X$.

As Srtas. Claudete Salinas Franzosi e Ana Tereza Leme D'Auria, responsáveis pelos trabalhos de datilogra fia, e ao Sr. Jaime Alves da Silva e demais pessoas do setor gräfico do Instituto de Geociēncias da Universidade de São Paulo, que imprimiram os exemplares, ficam também os agradecimentos do autor. 
B I BL I OGRAF I A

ALMEIDA, F.F.M. de - 1967 - Origem e evolução da plataforma Brasileira.Div.Geol.Min. D.N.P.M., Bol. (241), 36p.Rio de Janeiro.

ALMEIDA, F.F.M. de - 1969 - Diferenciação Tectōnica da Plataforma Brasileira. Congr.Bras.Geo1., 230, Salvador. Anais, Soc.Bras.Geol., $1: 29-46$.

ALMEIDA, F.F.M. de - 1971 - Geochronological division of the Precambrian of South America. R.Bras.Geoc., São Pauto, $\stackrel{1}{=}(1): 13-21$.

ALMEIDA, F.F.M. de - 1974 - Evolução tectōnica do Cráton do Guaporé comparada com a do Escudo Bāltico. R.Bras.Geoc. São Paulo $\underline{\underline{4}}$ (3): 191-204.

ALMEIDA, F.F.M. de; HASUI, Y. B BRITO NEVES, B.B.de - 1976 The Upper Precambrian of South America. Bol.IG., Inst. Geoc. USP, I: 45-80, São Paulo.

AMAPAL, G. - 1974 - Geologia prē-Cambriana da região Amazōnica. São Paulo, Universidade, Instituto de Geociências. 212 p./Tese de Livre Docência.

AMARAL, G.; CORDANI, U.G.; KAWASHITA, K. G REYNOLDS, J.H. 1966 - Potassium-argon dates of basaltic rocks from Southern Brazi1. Geoch. et Cosm.Acta, 30: 159-189, 0xford.

ANHAUSSER, C.R.; MASON, R., VILJOEN, M.J. G VILJOEN, R.P. 1969 - A reappraisal of some aspects of Precambrian shield geology. Geol.Soc.Am.Bul1. 80: 2175-2200. 
ARAUJ0, J.F.V. de; MONTALVAO, R.N.G. de; LIMA, M.I.C. de; FERNANDES, P.E.C.A.; CUNHA, F.M.B. da; FERNANDES C.A. C. छ, BASEI, M.A.S. - 1976 - Geologia. In: BRASIL. Departamento Nacional da Produção Mineral. Projeto FADAMBRASIL. Folha SA 21 Santarēm. Rio de Janeiro, 510 p. (Levantamento de Recursos Naturais, 10).

BARBOSA, 0. ६ RAMOS, J.R.A. - 1959 - Territōrio do Rio Branco; aspectos principais de geomorfologia, da geologia e das possibilidades minerais de sua zona seten trional. B.Div.Geol.Minera1., Rio de Janeiro, (196): $49 \mathrm{p}$.

BARRON, C.N. - 1969 - Notes on the stratigraphy of Guayana. In: Guyana Geological Conference, 70 Paramaribo, 1966 , Proceedings...Paramaribo Geological Survey Guyana, p. 101 .

BARROS, A.M.; ALVES, E.D. de 0., ARAUJ0, J.F.V.; LIMA, M.I. C. de, $\xi$ FERNANDES, C.A.C. - 1977 - Geologia. In: BRASIL. Departamento Nacional da Produção Mineral. Projeto RADAMBRASIL. Folha SB/SC18 JAVARI/CONTAMANA. Rio de Janeiro. I-161 p. (Levantamento de Recursos Naturais, $13)$.

BASEI, M.A.S. - 1973 - Geocronologia do Bloco BIII, Amapá. Belēm, Projeto RADAM, 9p. (Relatōrio Interno RADAM, $35-G)$.

BASEI, M.A.S. - 1973a - Geocronologia SB22/SC22. Belém,Pro jeto RADAM, 3p. (Relatörio Interno RADAM).

BASEI, M.A.S. - 1974 - Geocronologia da região Tapajōs-Iri ri. Belém, Projeto RADAM (Relatōrio Interno RADAM,16-G). 
BASEI, M.A.S. - 1977 - Idade do vulcanismo ācido-intermediā rio na região Amazônica. São Paulo, Universidade, Instituto de Geaciēncias, 133 p. (Dissertação de mestrado).

BASEI, M.A.S. $\xi$ TEIXEIRA, W. - 1975 - Geocronologia do Territōrio de Roraima. In: Conferēncia Geolōgica Interguianas, 10 a. Departamento Nacional da Produção Mineral, p. 253-273, Belēm.

BASEI, M.A.S. $\xi$ TEIXEIRA, W. - 1975a - Geocronologia e considerações estratigräficas preliminares da Região Cachimbo-Dardanelos. Belēm, Projeto RADAM, 19p. (Relatōrio Interno RADAM, 37-G).

BEISIEGEL, W. de R.; BERNARDELLI, A.L.; DRUMMOND, N.F.;RUFF, A.W. $\xi$ TREMAINE, J.W. - 1973 - Geologia e recursos mi nerais da Serra dos Carajäs. R.Bras.Geoc. $\underline{\underline{3}}$ (4): 215 242 .

BELLIZIA, C.M. - 1972 - Paleotectōnica del Escudo de Guayana. In: Conferēncia Geológica Inter-Guayanas, 9a.,Guayana, 1972. Memōria Guayana, Ministério de Minas y Hidrocarburos, (Boletin de Geologia. Publ. Especial no $6, p .251-305$.

BERRANGE, J.P. - 1967 - Progress report on photogeological mapping of Guyana south of 40 latitude-operation E1 Do rado. Inst.Geo1.Sci. London.

BERRANGE, S.P. - 1973 - A synopsis of the geology of Southern Guyana, London, Inst.Geo1.Sci. Overseas Div., 16p. (Re port, 26).

BRAUN, 0.P.G. G RAMGRAB, G.E. - 1972 - Geologia do Territōrio de Roraima (Res.) - Bo1. XXVI Congr.Bras.Geol. (2):68-70. 
BRITO NEVES, B.B.de - 1971 - Sintese da geologia e biblio grafia das coberturas e dobramentos prē-silurianos In: Simpōsio da Geologia do Nordeste, 5. Recife, 1971 Recife, Soc. Bras. Geo1., Nūcleo Nordeste, 51p. (Bol. Especia1, 2).

CAPUT0, M.V.; RODRIGUES, R. G VASCONCELOS, D.N.N.de - 1972Nomenclatura estratigrāfica da Bacia do Amazonas; histōrico e atualização. Anais...XXXVI Congr.Bras. Geol. 3: $35-46$.

ChOUBERT, B. - 1969 - Les Guyano-Eburneides de 1'Amērique du Sud et de 1'Afrique 0ccidentale; essais de comparation gēologique. B. B.R.G.M. sect, $\underline{\underline{4}}$ : 39-68.

CORDANI, U.G. - 1974 - Comentārios (Amapā). Belém, Projeto RADAM, 3p. (inēdito).

CORDANI, U.G.; BASEI, M.A.S.; TEIXEIRA, W.; TASSINARI, C.C. G. $\xi$ KAWASHITA, K. - 1978 - The Precambrian Geotecto nic Evolution of the Amazonian region based on structu ral and geochronological data. (inédito).

DALL'AGNOL, R. $\xi$ ABREU, A.S. - 1976 - Petrografia e amostra gem do Bloco E-IV, Folha NA 19 Pico da Neblina; relatō rio analîtico. Belēm, Projeto RADAMBRASIL, 78p. (Relatōrio Interno RADAMBRASIL, 77-G).

GOMES, C.B.; CORDANI, U.G. BASEI, M.A.S. - 1975 - Radiome tric ages from the Serra dos Carajās Ärea, Northern Brazi1. Geo1. Soc. Am. Bu11., 86: 939-942.

GUIMARAES, D. - 1929 - 0 processo de hyperstenização das ro chas do alto rio Branco. An. Acad.Bras. C1, Rio de Janeiro, 1 (4): 191-195.

GUIMARÁES, D. - 1930 - A provīncia magmātica do Roraima,Bra sil septentrional. B.Serv.Geol.Min.,Rio de Janeiro,(45): $57 p$. 
GUIMARAES, D. - 1947 - A provĩncia magmática do Roraima. B. Div. Geol. Min., Rio de Janeiro, (121): 109p.

HEBEDA, E.H.; BOELRIJK, N.A.I.M.; PRIEM, H.N.A.; VERDUMEN, E.A. Th. G VERSCHURE, R.H. - 1971 - Excess radiogenic argon in the precambrian Avanavero dolerite in Western Suriname (South America) Z.W.0. Laboratium voor Isotopen Geologie. Amsterdam, 1970: 17-36.

ISSLER, R.S. - 1975 - Geologia do Crāton Guianēs e suas pos sibilidades metalogenēticas. Belém, Projeto RADAMBRASIL, 25 p. (Relatōrio Interno, RADAMBRASIL, 61-G).

ISSLER, R.S. - 1975a - Magmatismo alcalino no Crāton Guiarès. In: Conferēncia Geolōgica Interguianas, 10 a. Anais...Departamento Nacional da Produção Mineral,1975, p. 103-122, Belēm.

ISSLER, R.S. - 1977 - Esboço Geolögico-Tectōnico do Crāton do Guaporé. R.Bras.Geoc., São Paulo $\underline{\underline{7}}$ (3): 177-211.

ISSLER, R.S.; ANDRADE, A.R.F. de; MONTALVAO, R.M.G. de; GUI MARAES, G.; SILVA, G.G. da $\xi$ LIMA, M.I.C. de - 1974 In: BRASIL. Departamento Nacional da Produção Mineral. Projeto RADAM. Folha SA 22 Belëm. Rio de Janeiro. I/ 60p. (Levantamento de Recursos Naturais, 5).

IWANUCH, W. - 1976 - Idades Rb/Sr das alcalinas do "Domo do Sucunduri", AM. In: Congresso Brasileiro de Geologia, 290, Belo Horizonte. Resumo das Comunicações. Belo Horizonte, Soc.Bras.Geol. p.196.

KAWASHITA, K. - 1972 - 0 método Rb/Sr em rochas sedimentą res. Aplicação para as bacias do Paraná e Amazonas.São Paulo, Universidade, Instituto de Geociências, 111 p. (Tese de Doutoramento). 
KRUNER, A. - 1977 - The Precambrian geotectonic evolution of Africa:plate accretion versus plate destruction. Precam brian Research. Amsterdam, 4: 163-213.

LEAL, J.W.L.; SILVA, G.H.; SALUM, 0.A.L.; SILVA, L.L.de; DRE HER, A.M. G BASEI, M.A.S. - 1974 - Esboço Geolögico de parte da Folha SC 20 Porto Velho. In: Congresso Brasileiro de Geologia, 289, Porto Alegre. Resumo das Comun $\underline{i}$ cações. Porto Alegre, Soc. Bras. Geol. (Bol.Especial, $1)$.

LIMA, M.I.C. de; MONTALVAO, R.M.G. de; ISSLER, R.S.; OLIVEIRA, A. da S.: BASEI, M.A.S.; ARAUJO, J.F.V. छ SILVA, G. G. da - 1974 -Geologia In: BRASIL Devartamento Nacional da Produção Mineral. Projeto RADAM. Folha NA/NB 22 Macapá. Rio de Janeiro, I/120 p. (Levantamento de Recur sos Naturais, 6).

MANDETTA, P. - 1970 - Datações geocronolōgicas de rochas do Territörio Federal de Roraima. Belëm, DNPM, 1970, Re 1. no 1472 .

MCCANDLES, G.C.; HIRATA, W.K.; TEIXEIRA, J.T. G.MEYER, D. J. K. - 1975 - 0 Complexo ígneo ácido da região central do Parā. Anais...Conf.Geol. Interguianas, 10a. Belēm.

McDOUGALL, I - 1968 - Isotoping dating of the Roraima dolerites. Geophys. J. London, 16: 141-145.

MCDOUGALL, I.; COMPSTON, W.; HAWKES, D.D. - 1963 - Leakage of radiogenic argon and strontium from minerals in proterozoic dolerites from British Guiana. Nature, London, 198 (4880): 564-567.

MONTALVAO, R.M.G. de - 1976 - Esboço Geolögico - Tectônico do Cráton Guianès. R.Bras.Geoc., São Paulo 6(4): 230-245. 
MONTALVAO, R.M.G. de G PITHAN, J.H.L. - 1974 - Grupo Tunuí. Belēm, Projeto RADAM, 7p. (Relatōrio Interno RADAM,44G).

MONTALVAO, R.M.G. de; MUNIZ, M. de B.; ISSLER, R.S.; DALL' AGNOL, R.; LIMA, M.I.C. de; FERNANDES, P.E.C.A. छ SILVA, G.G. da - 1975 - Geologia. In: BRASIL. Departamento Nacional da Produção Mineral. Projeto RADAMBRASIL. Fo1ha NA 20 Boa Vista e parte das folhas NA 21 Tumucumaque, NB 20 Roraima e NB 21. Rio de Janeiro. 428p. (Levantamento de Recursos Naturais, 8 ).

OLIVEIRA, A.I. de - 1929 - Bacia do Rio Branco. Estado do Amazonas. B.Serv. Geol.Mineral., Rio de Janeiro, (37): $71 p$.

OLIVEIRA, A.S.; FERNANDES, C.A.C.; ISSLER, R.S.; ABREU,A.S.; MONTALVAO, R.M.G. de $\xi$ TEIXEIRA, W. - 1975 - Geologia. In: BRASIL. Departamento Nacional da Produção Mineral. Projeto RADAMBRASIL Folha NA 21 Tumucumaque e parte da Folha NB 21. Rio de Janeiro, 361p. (Levantamento de Recursos Naturais, 9).

PAIVA, G. de - 1939 - Alto Rio Branco. B. Serv.Geol.Mineral., Rio de Janeiro, (99): $44 p$.

PINHEIRO, S.da S.; FERNANDES, P.E.C.A.; PEREIRA, E.R.; VAS CONCELOS E.G.; PINTO, A. do C.; MONTALVAO, R.M.G. de; ISSLER, R.S.; DALL'AGNOL, R.; TEIXEIRA, W. छ FERNANDES, C.A.C. - 1976 - Geologia. In: BRASIL. Departamento Nacional da Produção Mineral. Projeto RADAM. Folha NA 19 Pico da Neblina. Rio de Janeiro, 366p. (Levantamento de Recursos Naturais, 11 ).

PRIEM, H.N.A. - 1968 - Isotopic age determinations on Surina me rocks, III.Proterozoic and Permo-Triassic basalt mag matism in the Guyana Shield. Geol. Mijnbown, Hagne, $\underline{\underline{4}}$ (1): 17-20. 
PRIEM, H.N.A. - 1970 - Additional K-Ar measurements on Permo-Triassic dolerites from Suriname. Z.W.0. Laborato rium voor Isotopen Geologie. Ann. Rep.: 87-88.

PRIEM, H.N.A. - 1973 - Age of the Pre-Cambrian Roraima formation in Northestern South America: evidence from isotoping dating of Roraima piroclastic volcanics rocks in Suriname. Geo1. Soc.Am.Bu11,; Colorado, 84(5): 16671684 .

PRIEM, H.N.A.; BQELRIJK, N.A.I.M.; HEBEDA, E.H.; VERDUMEN, E.A.Th. G BON, E.H. - 1971 - Granitic Complexes and as sociated Tin mineralizations of "Greenville" age in Rondōnia, Western Brazi1. Geol.Soc.Am.Bu11. 82: 1095 1102 .

PRIEM, H.N.A.; BOELRIJK, N.A.I.M.; HEBEDA, E.H.; VERDUMEN, E.A.Th. $\xi$ VERSCHURE, R.H. - 1971a - Isotopic Ages of Trans-Amazonian acidic Magmatism and the Nickerie Meta morphic episode in the Precambrian Basement of Suriname, South America. Geo1. Soc. Am. Bu11. 82: 1667-1680.

RANGRAB, G.E.; BONFIM, L.F. da C. G MANDETTA, P. - 1972 -Pro jeto Roraima, 2a.fase. Manaus, DNPM/CPRM, 9v.

REZENDE, W.M. de $\xi$ BRITO, C.G. de - 1973 - Avaliação geolōgi ca da Bacia Paleozóica do Amazonas. Bol. XXVII Congr. Bras. Geo1. (2):150.

SANTOS, D.B. dOS; FERNANDES, P.E.C.A.; DREHER, A.M.; CUNHA, F.M.B. da; BASEI, M.A.S. G TEIXEIRA, J.B.G. - 1975 -Geo logia In: BRASIL. Departamento Nacional da Produção Mineral. Projeto RADAMBRASIL Folha SB 21 Tapajōs. Rio de Janeiro, 409p. (Levantamento de Recursos Naturais, 7). 
SANTOS, J.0.S. G SALAS, H.T. - 1974 - Notas sobre a primeira ocorréncia de rochas alcalinas no Territōrio Federal de Roraima. In: Congresso Brasileiro de Geologia, 280, Porto Alegre, 1974. Resumo das Comunicações. Porto Alegre, Soc.Bras.Geo1. (Bo1.1) p. 312-413.

SILVA, G.G.da; LIMA, M.I.C. de; ANDRADE, A.R.F.de; ISSLER, R.S. $\xi$ GUIMARAES,G. - 1974 - Geologia. In: BRASIL. Departamento Nacional da Produção Mineral. Projeto RADAM Folha SB 22 Araguaia e parte da folha SC 22 Tocantins. Rio de Janeiro, I/143p. (Levantamento de Recursos Natú rais, 4).

SILVA, G.H.; LEAL, J.W.L.; SALUM, O.A.L.; DALL'AGNOL, R. $\xi$ BASEI, M.A.S. - 1974 - Geologịa de parte da Folha SC 21 Juruena. In: Congresso Brasileira de Geologia, 280, Porto Alegre. Anais...Soc.Bras.Geol., v.bl, p.309-320.

SINGH, S. - 1974 - The tectonic evolution of that portion of the Guyana shield represented in Guyana; an evaluation of the present status of investigations and corre lations across the Guyana shield. R.Bras.Geoc., São Paulo, $\underline{\underline{4}}(1): 41-49$.

SNELLING, N.J. - 1963 - Age of the Roraima formation, Bri tish Guyana. Nature,London, 198 (4885): 1079-1080.

SNELLING, N.J. G MCCONNELL, R.B. - 1969 - The geochronology

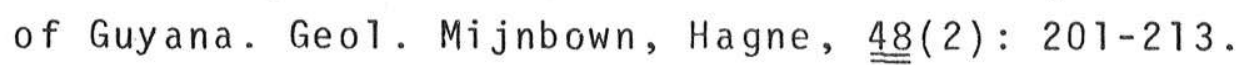

STOCKWELL, C.H. - 1961 - Structural Provinces, Orogenies, and Time-classification of the rocks of the Canadian. Precambrian Shield. Geological Survey of Canada. Ottawa, paper 61-17 (report 2): 108-118. 
STOCKWELL, C.H. - 1963 - Second Report on Structural Provinces, Orogenies, and Time-Classification of the Canadian Precambrian Shield. Geological Survey of Canada.0ttawa, paper 62-17 (report 3): 123-133.

STOCKWELL, C.H. - 1963a - Third Report on Structural Provinces, Orogenies, and Time-Classification of the Canadian Precambrian Shield. Geological Survey of Canada. Ottawa, paper 63-17 (report 4): 125-131.

SUSZCZYNSKI, E.F. - 1970 - La gēologie et la tectonique de la plataforme Amazonienne. Geol. Rundschau, Stuttgart, 59 (3): $1232-1253$.

TASSINARI, C.C.G. $\xi$ TEIXEIRA, W. - 1976 - Geocronologia da parte oriental da folha SC 19 Rio Branco.Belém, Projeto RADAMBRASIL. (Relatōrio Interno RADAMBRASIL - 84G).

TASSINARI, C.C.G. $\xi$ TEIXEIRA, W. - 1976a - Estudos Geocronolögicos da parte norte da folha SC 19 Içā. Belēm, Proje to RADAMBRASIL. (Relatōrio Interno, RADAMBRASIL, 102-G).

TASSINARI, C.C.G. $\xi$ TEIXEIRA, W. - 1977 - Geocronologia da folha SB 20 Purus. Belēm, Projeto RADAMBRASIL, 15p.(Relatörio Interno RADAMBRASIL).

TEIXEIRA, W.; BASEI, M.A.S. G TASSINARI, C.C.G. - 1976 - Geo cronologia das Folhas Tumucumaque e Santarém. In: Con gresso Brasileiro de Geologia, 290, Belo Horizonte. Resumo das Comunicações Belo Horizonte, Soc.Bras.Geol., (Bo1. 1) p.193.

TEIXEIRA, W. $\xi$ TASSINARI, C.C.G. - 1976 - Geocronologia e considerações sobre a evolução geolōgica da Folha NA 19 Pico da Neblina. Belérm, Projeto RADAMBRASIL, 17p. (Re latōrio Interno RADAMBRASIL, 60-G). 
TEIXEIRA, W. TASSINARI, C.C.G. - 1977 - Estudo geocronolō gico Rb/Sr e K/Ar da Folha SC 20 Porto Velho. Belém, Projeto RADAMBRASIL, 32p. (Relatōrio Interno RADAMBRASIL).

TEIXEIRA，W. G TASSINARI, C.C.G. - 1977a - Estudo geocronolögico da Folha SA 20 Manaus. Belēm, Projeto RADAMBRASIL, 16p. (Re 1atōrio Interno RADAMBRASIL).

THOMAZ, A.F.; CORDANI, U.G. G MARINO, 0. - 1974 - Idades K/Ar de rochas basālticas da bacia Amazōnica e sua sig nificação tectōnica regional. In: Congr.Bras.Geol.,280, Porto Alegre. v.6, p. 273-278.

TORquATO, J.R. - 1974 - Geologia do Sudoeste de Moçãmedes e suas relações com a evolução tectônica de Angola. São Paulo, Universidade Instituto de Geociências, 243p. (Te se de Doutoramento).

VERSCHURE, R.H. G BON, E.H. - 1972 - Geology and Geochronology of Tin-Bearing Volcano-plutonic complexes in Ron donia (western Brazil): reflexion on the genesis of this type of magmatism. Z.W.0. Laboratorium voor Isoto pen Geologie Ann. Rep.: 177-198. 
ANEXO 1: REFERENCIAS CONSTANTES NOS APENDICES 1, 1A, 2 e 2 A

FONTES:

1. RADAMBRASIL *

2. CPRM (dado inēdito, CPGeo) *

3. DOCEGEO (dado inēdito, CPGeo) *

4. IDESP (dado inēdito, CPGeo)

5. Amaral (1974) **

6. Thomaz Filho et al. (1974) **

7. Cordani e Mantovani (dado inëdito, CPGeo) *

LOCALIZAÇAO POR FOLHA AO MILIONESIMO:

A. Folha NA 19 Pico da Neblina

B. Folha NA/NB 20 Boa Vista

C. Folha NA 21 Tumucumaque

D. Folha NA/NB 22 Macapá

E. Folha SA 19 Içā

F. Folha SA 20 Manaus

G. Folha SA 21 Santarēm

H. Folha SA 22 Belēm

I. Folha SB 19 Juruã

J. Folha SB 20 Purus

K. Folha SB 21 Tapajōs

L. Folha SB 22 Araguaia

M. Folha SC 20 Porto Velho

N. Folha SC 22 Tocantins

0 . Folha SC 21 juruena

P. Folha SB 18 Javari

Obs.: * Apresentado com permissão

** Publicado 
APENDICE 1 - DADOS ANALITICOS K-AR PARA AS ROCHAS BÁSICAS

\begin{tabular}{|c|c|c|c|c|c|c|c|c|c|c|c|c|}
\hline Ordem & Nọ Campo & Folha** & Litologia & Mineral & No Lab & $\% \mathrm{~K}$ & $\operatorname{Ar}_{\mathrm{rad}}^{40} \frac{(\mathrm{ccSTP})}{\mathrm{g}} \times 10^{-6}$ & $\% \mathrm{Ar}_{\mathrm{atm}}^{40}$ & $\begin{array}{l}\text { I dade } \\
(\mathrm{m} . \mathrm{a} .\end{array}$ & & & $\operatorname{Ref}$ \\
\hline 1 & SACH $\times 263$ & $S B 21 \times C$ & Dolerito & PLAG. & 3.691 & $1,11 *$ & 158,50 & 11,56 & 2.000 & \pm & 95 & $4 K$ \\
\hline 2 & PTB / UC 19 & NA2 TYD & Hip.01iv.Diabāsio & PLAG. & 3.173 & 0,10 & 13,00 & 9,07 & 1.946 & \pm & 57 & $1 \mathrm{C}$ \\
\hline 3 & N5F7 & SB22ZA & Diabāsio & RT & 2.104 & 2,65 & 348,20 & 1,18 & 1.905 & \pm & 58 & $5 \mathrm{~L}$ \\
\hline 4 & RR6 8 & NB20ZD & Diabāsio & RT & 1.889 & 0,72 & 94,15 & 4,09 & 1.891 & \pm & 69 & $5 B$ \\
\hline 5 & MIFO 3 & SC $22 \times A$ & Diabāsio & RT & 2.623 & 0,75 & 97,99 & 2,58 & 1.886 & \pm & 40 & $4 N$ \\
\hline 6 & RR67. 3 & NB 20ZD & Diabāsio & RT & 1.820 & 0,50 & 57,84 & 26,93 & 1.757 & \pm & 81 & $5 B$ \\
\hline 7 & PNJFO 4 & NA20ZB & Gabro & PLAG. & - & 0,34 & 36,14 & 2,69 & 1.646 & \pm & 55 & $5 B$ \\
\hline 8 & RR 148 & NB $20 Z B$ & Gabro & RT & 1. 720 & 0,91 & 94,42 & 8,03 & 1.635 & \pm & 60 & $5 B$ \\
\hline 9 & RR70. 1 & NB $20 Z B$ & Diabāsio & RT & 1.893 & 0,71 & 69,96 & 5,49 & 1.574 & \pm & 60 & $5 B$ \\
\hline 10 & CRE I 40 & SB21ZA & Diabāsio & PLAG. & - & 1,57 & 150,50 & 0,90 & 1.553 & \pm & 26 & $1 \mathrm{~K}$ \\
\hline 14 & $6 / 628 / 69$ & SB22YD & Diabāsio & RT & 1.883 & 2,14 & 195,00 & 2,36 & 1.496 & \pm & 55 & $5 \mathrm{~L}$ \\
\hline 15 & PA393 & SB22YD & Di abāsio & RT & 1.872 & 0,44 & 40,15 & 7,58 & 1.492 & \pm & 16 & $5 \mathrm{~L}$ \\
\hline 16 & AM3 10 & SB22YD & Diabāsio & $\mathrm{RT}$ & 3.206 & 0,79 & 71,70 & 14,10 & 1.491 & \pm & 31 & $3 \mathrm{~L}$ \\
\hline 17 & N5F7 & SB22ZA & Diabāsio & RT & 2.105 & 5,37 & 485,20 & 2,25 & 1.488 & \pm & 13 & $5 \mathrm{~L}$ \\
\hline 18 & $A S 229 B$ & $S B 21 \times B$ & Diabāsio & RT & - & 2,27 & 202,20 & 0,40 & 1.475 & \pm & 65 & $1 \mathrm{~K}$ \\
\hline 19 & $23 A 66$ & SB22YD & Gabro & RT & 817 & 1,99 & 171,70 & 5,82 & 1.439 & \pm & 38 & $5 \mathrm{~L}$ \\
\hline 20 & PT26.2 & SB 20ZD & Diabāsio & $\mathrm{RT}$ & 3.569 & $1,78 *$ & 151,80 & 0,48 & 1.429 & \pm & 16 & $1 \mathrm{~J}$ \\
\hline 21 & PT292D & NA20VD & Diabāsio & PLAG. & - & 1,28 & 108,00 & 4,95 & 1.420 & \pm & 58 & $5 B \stackrel{c}{!}$ \\
\hline
\end{tabular}


APENDICE 1 - continuação

\begin{tabular}{|c|c|c|c|c|c|c|c|c|c|c|c|c|}
\hline 22 & PTJ 8 & SA2TVA & Diabāsio & PLAG. & 3.203 & 1,09 & 92,44 & 3,70 & 1.420 & \pm 3 & 32 & $I G$ \\
\hline 23 & PT36 & SB20ZB & Metadiabāsio & RT & 3.576 & $1,59 *$ & 126,10 & 1,63 & 1.420 & \pm 2 & 22 & $1 \mathrm{~J}$ \\
\hline 24 & TR79 & SA21 VB & Diabāsio & RT & 1.944 & 1,85 & 154,00 & 2,19 & 1.408 & \pm 5 & 50 & $5 G$ \\
\hline 25 & PT17 & SA21VB & Diabāsio & PLAG. & 3.199 & 2,93 & 238,00 & 0,80 & 1.385 & \pm 3 & 39 & $1 G$ \\
\hline 26 & PTJ7 & SA21VA & Diabāsio & RT & 3.240 & 0,78 & 62,77 & 1,30 & 1.376 & \pm 1 & 19 & $1 G$ \\
\hline 27 & РT21B & SA21 VA & 01 iv.Diabāsio & PLAG. & 3.201 & 0,76 & 61,78 & 2,00 & 1.375 & \pm 3 & 37 & $1 G$ \\
\hline 28 & PT26. 1 & SC20XD & Basa 1 to & RT & 3.568 & $2,14 *$ & 171,30 & 2,20 & 1.366 & \pm 1 & 18 & $1 M$ \\
\hline 29 & PT18.1 & SB20ZB & 01 iv. Diabāsio & PLAG. & 3.588 & 0,66 * & 52,90 & 1,59 & 1.366 & \pm 1 & 15 & $1 \mathrm{~J}$ \\
\hline 30 & CUJ-1 & NA2OVB & Diabāsio & RT & 1.887 & 0,70 * & 54,11 & 33,66 & 1.336 & \pm 6 & 65 & $5 B$ \\
\hline 31 & IMM $30 \mathrm{C}$ & NA2 $1 Z A$ & Bas a 1 to & RT & 3.680 & $1,21 *$ & 93,00 & 1,06 & 1.333 & \pm 6 & 67 & $4 C$ \\
\hline 32 & CB15 & $S C 21 Z B$ & Diabāsio & RT & 3.40 .2 & 0,88 & 67,90 & 1,15 & 1.333 & \pm 4 & 43 & 70 \\
\hline 33 & $C B 11$ & $S C 21 Z B$ & Diabāsio & RT & 3.401 & 2,76 & 210,10 & 0,41 & 1.321 & \pm 5 & 58 & 70 \\
\hline 34 & CB 19 & $S C 21 Z B$ & Gabro & PLAG. & 3.400 & 0,79 & 57,20 & 9,19 & 1.272 & \pm 2 & 20 & 70 \\
\hline 35 & RON 16 & SC2OVD & Gabro & ANF. & - & 0,16 & 11,20 & 75,00 & $1.244^{\prime}$ & *** & & $5 M$ \\
\hline 36 & 1518AA 143 & SC2OVC & Gabro & RT & 3.486 & $1,37 *$ & 96,30 & 6,38 & 1.243 & \pm 1 & 15 & $2 M$ \\
\hline 37 & PT 1. I I I & SB20ZD & Diabāsio & PLAG. & 3.578 & 1,65 * & 115,80 & 1,57 & 1.241 & \pm 1 & 15 & $1 \mathrm{~J}$ \\
\hline 38 & PT60.2 & SC20VA & 01 iv.Diabāsio & RT & 3.334 & $2,07 *$ & 136,90 & 0,70 & 1.188 & \pm 1 & 13 & $1 \mathrm{M}$ \\
\hline 39 & PT09.I I & SB20ZD & Metadiabāsio & PLAG. & 3.585 & 2,51 * & 161,60 & 0,85 & 1.167 & \pm 2 & 25 & $1 \mathrm{~J}$ \\
\hline 40 & PT29 & SA2IVA & 01 iv.Diabásio & PLAG. & 3.181 & 2,66 & 170,30 & 0,80 & 1.164 & \pm 6 & 62 & $I G$ \\
\hline 41 & $1518 . J A 257$ & SC2OVC & Diabāsio & RT & 3.487 & $0,84 *$ & 54,11 & 2,57 & 1.164 & \pm 2 & 23 & $2 M$ \\
\hline
\end{tabular}


APÊNDICE 1 - continuação

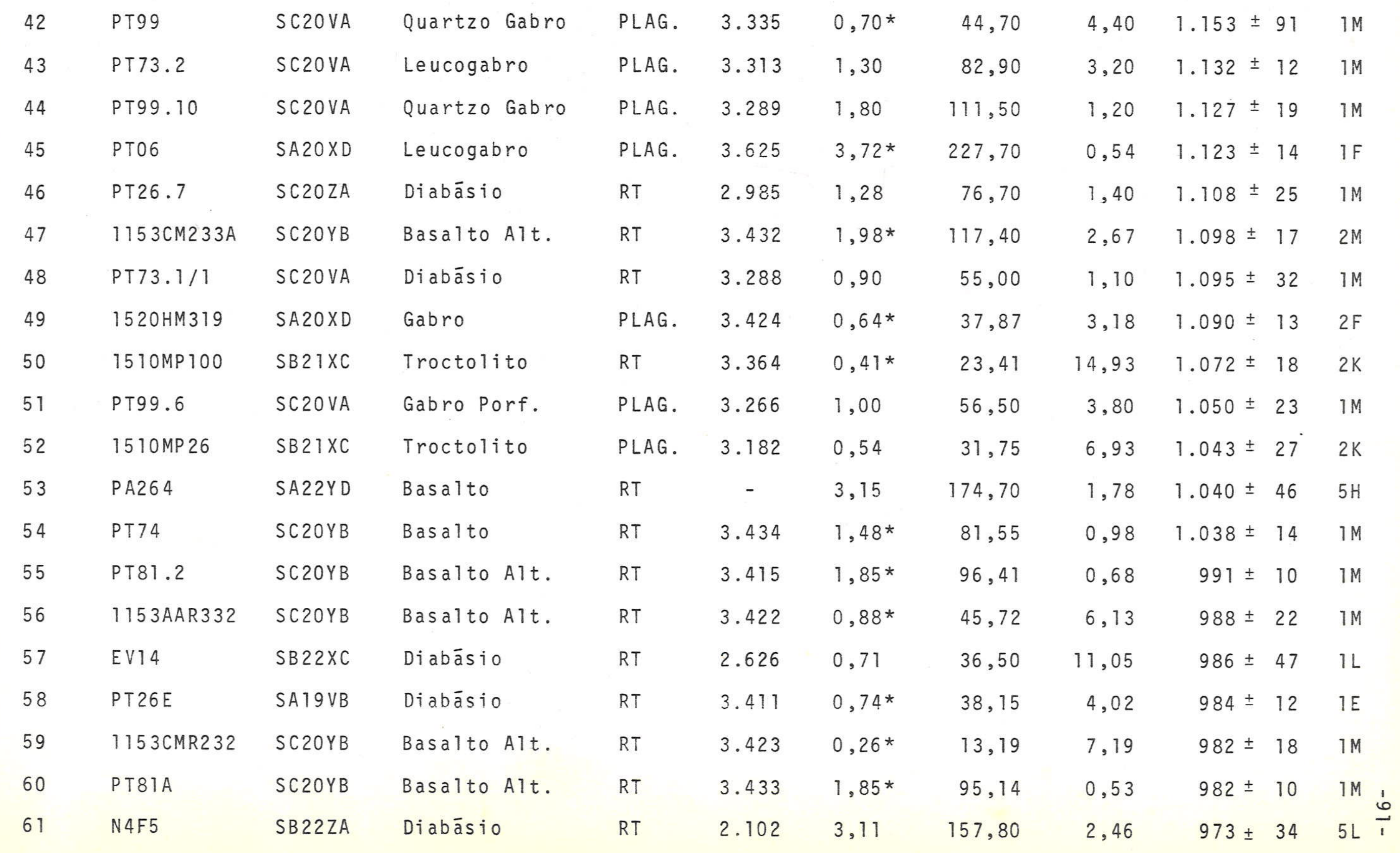


APENDICE 1 - continuação

\begin{tabular}{|c|c|c|c|c|c|c|c|c|c|c|c|}
\hline 62 & 1153 AAR 335 & SC2OYB & Basalto Alt. & RT & 3.431 & $1,07 *$ & 53,73 & 1,91 & 967 & \pm 17 & $1 M$ \\
\hline 63 & N4F5 (Rep.) & SB22ZA & Diabāsio & RT & 2.103 & 2,67 & 131,80 & 5,63 & 951 & \pm 14 & $5 \mathrm{~L}$ \\
\hline 64 & PT $35 \mathrm{~A}$ & SA19VB & Diabāsio & PLAG. & 3.409 & $1,11 *$ & 53,90 & 3,56 & 941 & \pm 14 & $1 \mathrm{E}$ \\
\hline 65 & AN84C & SA21VA & Diabāsio & PLAG. & 3.607 & 0,91 * & 39,44 & 2,79 & 854 & \pm 12 & $2 G$ \\
\hline 66 & JFOT & SA2IVC & Diabāsio & PLAG. & 3.594 & $2.45 *$ & 103,10 & 1,06 & 839 & \pm 22 & $2 G$ \\
\hline 67 & AA7 -37 & SB22ZA & Diabāsio & RT & 749 & 1,22 & 28,60 & 23,94 & 512 & \pm 20 & $5 \mathrm{~L}$ \\
\hline 68 & AS 297 & SA22ZC & Basal to & RT & 2.920 & 0,25 & 5,85 & 17,20 & 510 & \pm 15 & $3 \mathrm{H}$ \\
\hline 69 & AS 296 & SA22ZC & Basal to & RT & 2.921 & 0,55 & 12,75 & 17,40 & 509 & \pm 15 & $3 \mathrm{H}$ \\
\hline 70 & OFS 74 & SB22XC & Diabāsio & RT & 1.793 & 0,68 & 15,80 & 15,69 & 507 & \pm 29 & $5 \mathrm{~L}$ \\
\hline 71 & $66 A 66$ & SA22ZC & Diabāsio & RT & 921 & 1,84 & 42,10 & 3,12 & 501 & \pm 18 & $5 \mathrm{H}$ \\
\hline 72 & JLR665 & NA22 VC & Diabāsio & RT & - & 0,61 & 12,73 & 28,50 & 463 & \pm 18 & $5 \mathrm{D}$ \\
\hline 73 & CA 110 & $S A 21 \times B$ & Diabāsio & RT & 1.941 & 1,80 & 33,43 & 27,17 & 416 & \pm 7 & $5 G$ \\
\hline 74 & RR 143 & NA20XB & Diabāsio & RT & 1.698 & 0,49 & 8,18 & 24,12 & 372 & \pm 22 & $5 B$ \\
\hline 75 & RR226 & NA20XB & Diabāsio & RT & 1.885 & 0,35 & 0,35 & 5,49 & 356 & \pm 32 & $5 B$ \\
\hline 76 & 17528 & SB22XC & Diabāsio & RT & 2.560 & 0,15 & 2,30 & 82,14 & 348 & \pm 20 & $5 \mathrm{~L}$ \\
\hline 77 & FGSTIAM & SBI9YA & Basal to & RT & 638 & 0,96 & 12,79 & 6,69 & 307 & \pm 12 & $5 \mathrm{I}$ \\
\hline 78 & AP 106 & SA22ZC & Basalto & RT & 2.722 & 0,61 & 7,70 & 35,10 & 300 & \pm 50 & $5 \mathrm{H}$ \\
\hline 79 & MA 1 PA 40 & SA21ZB & Basal to & PLAG. & 1.309 & 0,22 & 2,43 & 69,00 & 259 & \pm 6 & $6 G$ \\
\hline 80 & JLR5 14 & NA22 VD & Diabāsio & PLAG. & - & 0,90 & 9,67 & 47,10 & 254 & \pm 27 & 5D \\
\hline
\end{tabular}


APENDICE 1 - continuação

\begin{tabular}{|c|c|c|c|c|c|c|c|c|c|c|c|c|}
\hline 81 & MIAB 32 & SA20VA & Diabāsio & PLAG. & 3.609 & $0,7.4$ * & 7,83 & 16,80 & 248 & \pm & 4 & $1 \mathrm{~F}$ \\
\hline 82 & I ÇEA2 4 & NA19ZA & Diabāsio & RT & 3.252 & 0,75 & 7,77 & 6,44 & 242 & \pm & 5 & $1 \mathrm{~A}$ \\
\hline 83 & MA 1 PA 35 & $S A 21 Z B$ & Bas al to & RT & 1.311 & 0,35 & 3,35 & 64,50 & 232 & \pm & 19 & $6 G$ \\
\hline 84 & $A A 7-2$ & $S B 22 \times C$ & Diabāsio & RT & 844 & 0,28 & 2,80 & 69,70 & 232 & \pm & 22 & $.5 \mathrm{~L}$ \\
\hline 85 & GSO 8 & NA2 2 VB & Diabásio & PLAG. & - & 0,45 & 4,43 & 41,30 & 227 & \pm & 10 & $5 D$ \\
\hline 86 & $C R / A 0372$ & NA22 VB & Diabāsio & PLAG. & - & 0,51 & 4,87 & 29,10 & 224 & \pm & 17 & $5 \mathrm{D}$ \\
\hline 87 & PT66I I & SB20ZD & Diabāsio & PLAG. & 3.583 & $0,87 *$ & 8,21 & 20,50 & 222 & \pm & 3 & $1 \mathrm{~J}$ \\
\hline 88 & LAST-IAM & SB 20 VD & Diabās io & RT & 10 & 0,40 & 3,72 & 73,40 & 219 & \pm & 7 & $5 \mathrm{~J}$ \\
\hline 89 & PT23. I I & SB 20ZD & Diabāsio & $\mathrm{RT}$ & 3.577 & $0,40 *$ & 3,69 & 61,40 & 218 & \pm & 8 & $1 \mathrm{~J}$ \\
\hline 90 & IÇEA 42.A & NAT 19 YB & Diabāsio & $\mathrm{RT}$ & 3.250 & 0,76 & 6,99 & 18,57 & 218 & \pm & 2 & $1 \mathrm{~A}$ \\
\hline 91 & IBSTIPA & $S A 22$ VB & Diabāsio & RT & - & 0,73 & 6,55 & 17,68 & 213 & \pm & 7 & $5 \mathrm{H}$ \\
\hline 92 & NOIAM & SB21VA & Basalto & PLAG. & 2.805 & 0,35 & 2,97 & 63,60 & 210 & \pm & 21 & $6 K$ \\
\hline 93 & 13178 & SB22ZA & Diabāsio & RT & 2.558 & 0,70 & 6,20 & 82,95 & 210 & \pm & 14 & $5 \mathrm{~L}$ \\
\hline 94 & PT02A (NERL63) & SA20ZB & Diabāsio & RT & 3.601 & $0,42 *$ & 3,68 & 21,20 & 209 & \pm & 8 & $1 \mathrm{~F}$ \\
\hline 95 & NOVA OLINDA & NA20XD & Bas al to & $\mathrm{RT}$ & 1.900 & 1,79 & 15,64 & 36,90 & 208 & \pm & 14 & $5 B$ \\
\hline 96 & JLR6 $67 \mathrm{~B}$ & NA22 VD & Diabāsio & PLAG. & - & 0,18 & 1,54 & 42,40 & 207 & \pm & 18 & $5 \mathrm{D}$ \\
\hline 97 & RPIPA & SA22 VA & Bas a 1 to & RT & 2.958 & 0,78 & 6,69 & 42,00 & 204 & \pm & 6 & $6 \mathrm{H}$ \\
\hline 98 & AD405 & SB22XC & Diabāsio & $\mathrm{RT}$ & 3.209 & 0,75 & 6,36 & 15,60 & 203 & \pm & 6 & $3 L$, \\
\hline 99 & PT09/EP06 & NA2 1 Y B & Diabāsio & PLAG. & 3.325 & 1,06 & 8,96 & 13,90 & 202 & \pm & 9 & $1 A_{1}^{\omega}$ \\
\hline
\end{tabular}


APENDICE 1 - continuação

\begin{tabular}{|c|c|c|c|c|c|c|c|c|c|c|c|c|}
\hline 100 & PT02 & NA21ZA & Diabāsio & PLAG. & 3.073 & 0,79 & 6,69 & 25,20 & 201 & \pm 2 & 23 & $1 C$ \\
\hline 101 & RR203.4 & NA2 IVA & Gabro & RT & 1.895 & 0,60 & 5,10 & 56,68 & 201 & \pm 1 & 18 & $5 C$ \\
\hline 102 & MA 7AM & $S A 21 Y C$ & Diabāsio & RT & 3 & 0,45 & 3,72 & 16,03 & 196 & \pm 7 & 7 & $5 \mathrm{~F}$ \\
\hline 103 & $A B 7$ & SA22YC & Diabāsio & PLAG. & 2.994 & 0,58 & 4,59 & 45,40 & 188 & \pm 6 & 6 & $\mathrm{IH}$ \\
\hline 104 & PTX & SA21XD & Diabāsio & PLAG. & 3.198 & 0,38 & 2,95 & 32,30 & 183 & \pm 1 & 14 & $I G$ \\
\hline 105 & RR202.1 & NA2 $20 \times B$ & Bas a 1 to & RT & 1.901 & 0,83 & $6,2: 2$ & 75,51 & 179 & \pm 3 & 33 & $5 B$ \\
\hline 106 & AM104 & SB20ZD & Diabāsio & $\mathrm{RT}$ & - & 0,07 & 5,36 & 39,47 & 179 & \pm 3 & 3 & $5 \mathrm{~J}$ \\
\hline 107 & RTG4-67 & NA2 IVC & Basal to & RT & 1.075 & 1,37 & 10,11 & 31,31 & 177 & \pm 1 & 16 & $5 B$ \\
\hline 108 & PT17C & SB2 IYD & Diabāsio & RT & - & 0,98 & 7,26 & 27,30 & 177 & $\pm \varepsilon$ & 8 & $1 \mathrm{~K}$ \\
\hline 10.9 & JLR5 30 & NA20 VD & Diabāsio & PLAG. & - & 0,65 & 4,76 & 10,70 & $176=$ & \pm 9 & 9 & $5 B$ \\
\hline 110 & M114 & $S A 21 \times D$ & Diabāsio & PLAG. & 3.200 & 0,31 & 2,27 & 35,30 & 175 & \pm 1 & 15 & $I G$ \\
\hline 111 & $A B 4$ & SA22YC & Diabāsio & PLAG. & 2.779 & 0,71 & 5,09 & 20,27 & 171 & \pm 9 & 9 & $\mathrm{TH}$ \\
\hline 112 & CS2AM & SA20ZC & Basalto & $\mathrm{RT}$ & 2.831 & 0,61 & 4,29 & 50,90 & 165 & \pm 7 & 7 & $6 C$ \\
\hline 113 & BV-CARAC. & NA20XD & Bas a 1 to & RT & 1.906 & 0,42 & 2,78 & 82,04 & 161 & \pm 1 & 17 & $5 B$ \\
\hline 114 & MOVA OLINDA & NA20XD & Basalto & RT & 1.913 & 1,79 & 11,26 & 26,28 & 152 & \pm 1 & 13 & $5 B$ \\
\hline 115 & $2-67-34$ & NA20XB & Basa 1 to & $\mathrm{RT}$ & 1.071 & 1,37 & 10,10 & 30,80 & $151=$ & \pm 3 & 38 & $6 B$ \\
\hline 116 & RR221.1 & NA2 $20 \times D$ & Bas a 1 to & RT & 1.891 & 0,37 & 2,30 & 80,18 & $151=$ & \pm 1 & 14 & $5 B$ \\
\hline 117 & RR223.1 & NA2 $20 \times D$ & Basal to & $\mathrm{RT}$ & 1.888 & 1,18 & 7,24 & 34,44 & 148 & \pm 9 & 9 & $5 B$ \\
\hline 118 & $R T G-2-67$ & NA2 I ZC & Basal to & $\mathrm{RT}$ & 1.090 & 0,93 & 5,66 & 31,52 & 146 & \pm 4 & 4 & $5 C$ \\
\hline 119 & PТ11A & $S B 21 \times A$ & Diabāsio & PLAG. & - & 0,54 & 3,21 & 27,80 & 144 & \pm 6 & 6 & $1 \mathrm{~K}$ \\
\hline
\end{tabular}


APENDICE 1 - continuação

\begin{tabular}{|c|c|c|c|c|c|c|c|c|c|c|}
\hline 120 & РТ09B & SA21XC & Diabāsio & $\mathrm{RT}$ & 3.242 & 0,48 & 2,84 & 10,60 & $143 \pm 6$ & \\
\hline 121 & MA 1 PA 31 & $S A 21 Z B$ & Basalto & PLAG. & 1.310 & 0,36 & 2,09 & 40,70 & $140 \pm \epsilon$ & 6 \\
\hline 122 & M143 & SA2TXD & Diabāsio & PLAG. & 3.197 & 0,39 & 2,16 & 47,50 & $135 \pm$ & 53 \\
\hline 123 & $A B 9$ & SA22YC & Diabāsio & PLAG. & 2.776 & 0,31 & 1,69 & 42,00 & $130 \pm$ & 6 \\
\hline 124 & RR 156 & NB2.0ZD & Basalto & RT & 1.697 & 1,02 & 5,33 & 76,50 & $127 \pm$ & 12 \\
\hline 125 & MA2AM & $S A 21 Z B$ & Basalto & PLAG. & 2.754 & 0,33 & 1,71 & 57,70 & $126 \pm$ & 6 \\
\hline 126 & AT36 & $S A 22 Z C$ & Gabro & PLAG. & 2.731 & 0,21 & 0,89 & 97,30 & $105 \pm$ & 15 \\
\hline
\end{tabular}

Constantes utilizadas:

$\lambda_{\beta}=0,530 \times 10^{-9} \mathrm{anos}^{-1}$

$\lambda_{\varepsilon}=0,585 \times 10^{-10}$ anos $^{-1}$

$\%$ atom.de $k^{40}$ em $K^{\text {tot }}=0,0119$
Obs.:

* por Absorção Atōmica

** Folha $1: 250.000$

*** erro analítico não disponível no trabalho original (Para referéncias, consultar Anexo 1) 
APENDICE IA: DADOS ANALITICOS Rb/Sr DO HORNFELS DO DIABASIO PEDRA PRETA

\begin{tabular}{|c|c|c|c|c|c|c|c|c|c|c|}
\hline lo Ordem & Nọ Campo & Folha* & Litologia & No Lab & $\mathrm{Rb}(p \mathrm{pm})$ & $S r(p p m)$ & $S r^{87} / s r^{86 * *}$ & $\mathrm{Rb}^{87} / \mathrm{S} r^{86}$ & $\begin{array}{c}\text { Idade } \\
(\mathrm{m} . \mathrm{a} .)\end{array}$ & $\operatorname{Re} f$. \\
\hline 11 & MM96 & NA20ZD & Hornfels & 1.098 & 219,1 & 101,9 & 0,8778 & 6,33 & $1.830 \pm 60$ & $1 B$ \\
\hline 12 & MM95 & NA20ZD & Hornfels & 1.095 & 211,8 & 122,5 & 0,8412 & 5,07 & $1.800 \pm 70$ & $1 \mathrm{~B}$ \\
\hline 13 & MM9 4 & NA2OZD & Hornfels & 1.097 & 203,4 & $13.2,3$ & 0,8254 & 4,50 & $1.800 \pm 70$ & $1 B$ \\
\hline
\end{tabular}

Constantes utilizadas:

$\lambda_{\mathrm{Rb}}=1,47 \times 10^{-11} \mathrm{anos}^{-1}$

$\mathrm{Rb}^{85} / \mathrm{Rb}^{87}=2,59$

$\left(\mathrm{S} r^{87} / \mathrm{Sr}{ }^{86}\right)_{i}=0,705$

** valores normalizados para $S r^{86} / \mathrm{Sr}^{88}=0,1194$

ANALISES EM ROCHA TOTAL
Obs.:

* Folha $1: 250.000$

(Para referências, consultar Anexo 1) 
APENDICE 2: DADOS ANALITICOS Rb/Sr PARA O MAGMATISMO ALCALINO

\begin{tabular}{|c|c|c|c|c|c|c|c|c|c|c|}
\hline MOOrdem & No Campo & Folha*** & Litologia & No Lab & $\mathrm{Rb} \quad(p p m)$ & $S r \quad(p p m)$ & $s r^{87} / s r^{86 *}$ & $\mathrm{Rb}^{87} / \mathrm{S} r^{86}$ & $\begin{array}{c}\text { I dade } \\
(\text { m.a. })\end{array}$ & $\operatorname{Ref}$. \\
\hline 127 & PT16 & NA27ZD & Quartzo Sienito & 639 & 72,6 & 42,9 & 0,8392 & 4,950 & $1.806 \pm 69$ & $1 \mathrm{C}$ \\
\hline 128 & ID2 & NA22YA & Litchfieldito & .692 & 219,1 & 33,0 & 1,1710 & 18,640 & $1.680 \pm 63$ & 10 \\
\hline 129 & I D3 & NA22YC & Alcali Sienito & 693 & 108,4 & 20,2 & 1,0460 & 14,930 & $1.537 \pm 38$ & 10 \\
\hline 130 & IDI & NA22YA & Nefelina Sienito & .694 & 250,2 & 60,1 & 0,9357 & 11,640 & $1.335 \pm 39$ & 10 \\
\hline 131 & PT 40 & NA2 TYD & Quartzo Sienito & 1.120 & 118,5 & 13,9 & 1,2268 & 25,610 & $1.479 \pm 49$ & $1 C$ \\
\hline 132 & RCMO6 & SA2 IXD & Nordmarkito & 2.862 & 743,6 & $33 ; 5$ & 2,3345 & 74,580 & $1.470 \pm 34$ & $4 G$ \\
\hline 133 & M02 & SC21VA & Sienito & 954 & 178,2 & 8,4 & 2,1376 & 69,219 & $1.394 \pm 40$ & 10 \\
\hline 13.4 & $W-129$ & SC21VA & Fonolito & 1.255 & 271,5 & 10,5 & 2,1798 & 85,736 & $1.160 \pm 36$ & 10 \\
\hline 135 & PT66B & $S C 20 X B$ & Granito a biotita & 2.961 & 390,3 & 12,8 & 2,8964 & 105,740 & $1.393 \pm 35$ & $I M$ \\
\hline 136 & PT66A1 & $S C 20 \times B$ & Quartzo Sienito & 1.920 & 133,4 & 340,7 & 0,7267 & 1,136 & $1.289 \pm 179$ & IM \\
\hline 137 & PT66.] (Topo) & $S C 20 \times B$ & Quartzo Sienito & 2.047 & 204,3 & 31,2 & 1,0621 & 19,620 & $1.227 \pm 33$ & $T M$ \\
\hline 138 & PT66A3 & SC20XB & Quartzo Sienito. & 2.050 & 180,2 & 130,6 & 0,7711 & 4,020 & $1.109 \pm 52$ & $1 M$ \\
\hline 139 & PT99-11 & SC20VA & Quartzo Monzonito & 1.767 & 364,5 & 58,1 & 1,0606 & 18,797 & $1.275 \pm 37$ & $1 M$ \\
\hline 140 & PT46A2 & SC20VB & Pir.Anf.Sienito & 1.844 & 112,8 & 102,8 & 0,7642 & 3,195 & $1.249 \pm 60$ & $1 M$ \\
\hline 141 & PT46 & SC20 VB & Anf.Pir.Sienito & 1.837 & 77,3 & 142,2 & 0,7331 & 1,578 & $1.201 \pm 104$ & $1 \mathrm{M}$ \\
\hline 142 & HSO 5 & SC2TYA & Granito & 755 & 249,7 & 14,4 & 1,6730 & 54,310 & $1.202 \pm 30$ & 10 \\
\hline 143 & GG06. 1 & SC21YA & Sienito & 758 & 100,2 & 14,9 & 1,0490 & 19,820 & $1.169 \pm 33$ & 10 \\
\hline
\end{tabular}


ÍNDICE 2 - continuação

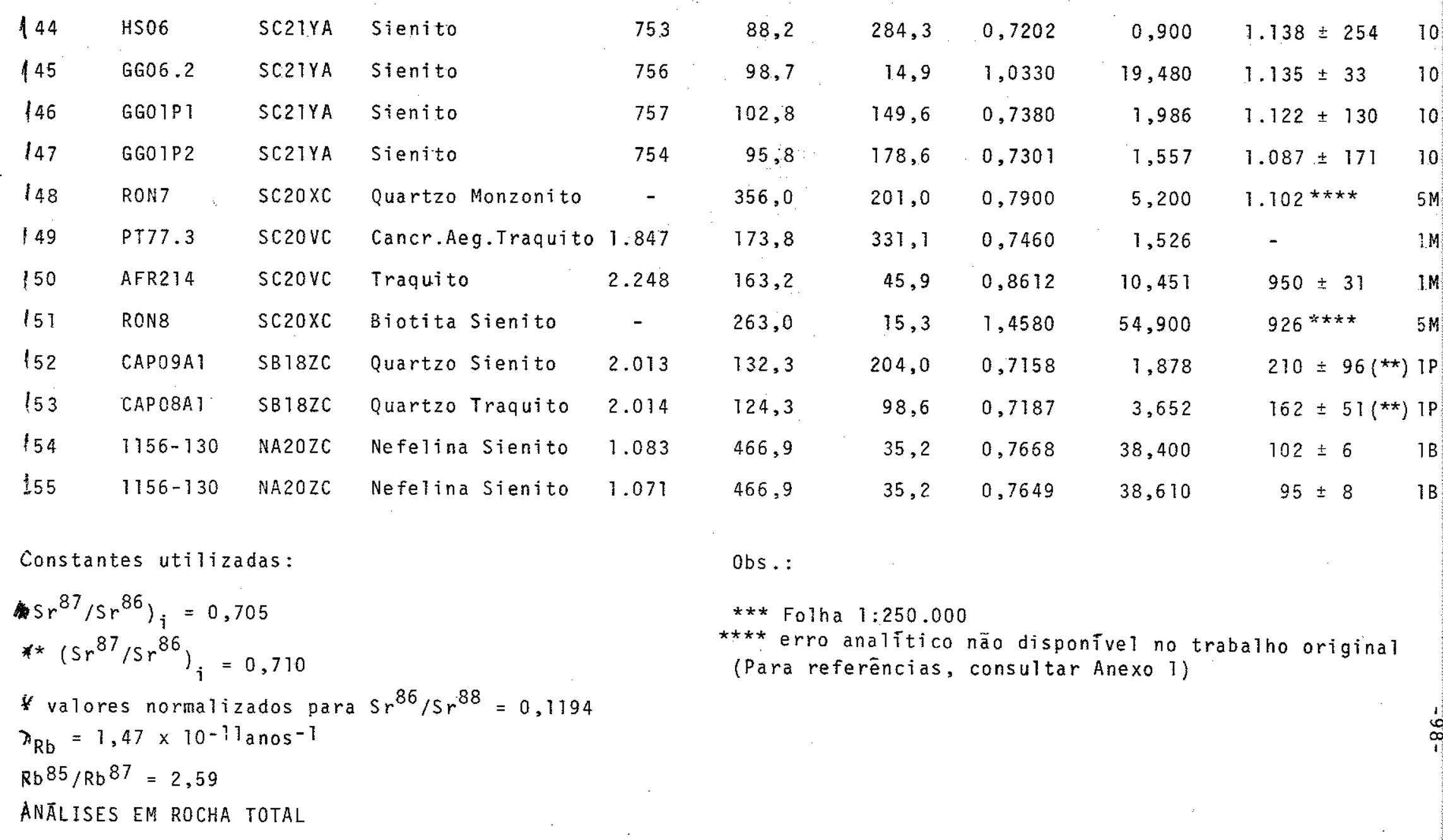


APENDICE 2A: DADOS ANALITICOS K/AR PARA O MAGMATISMO ALCALINO

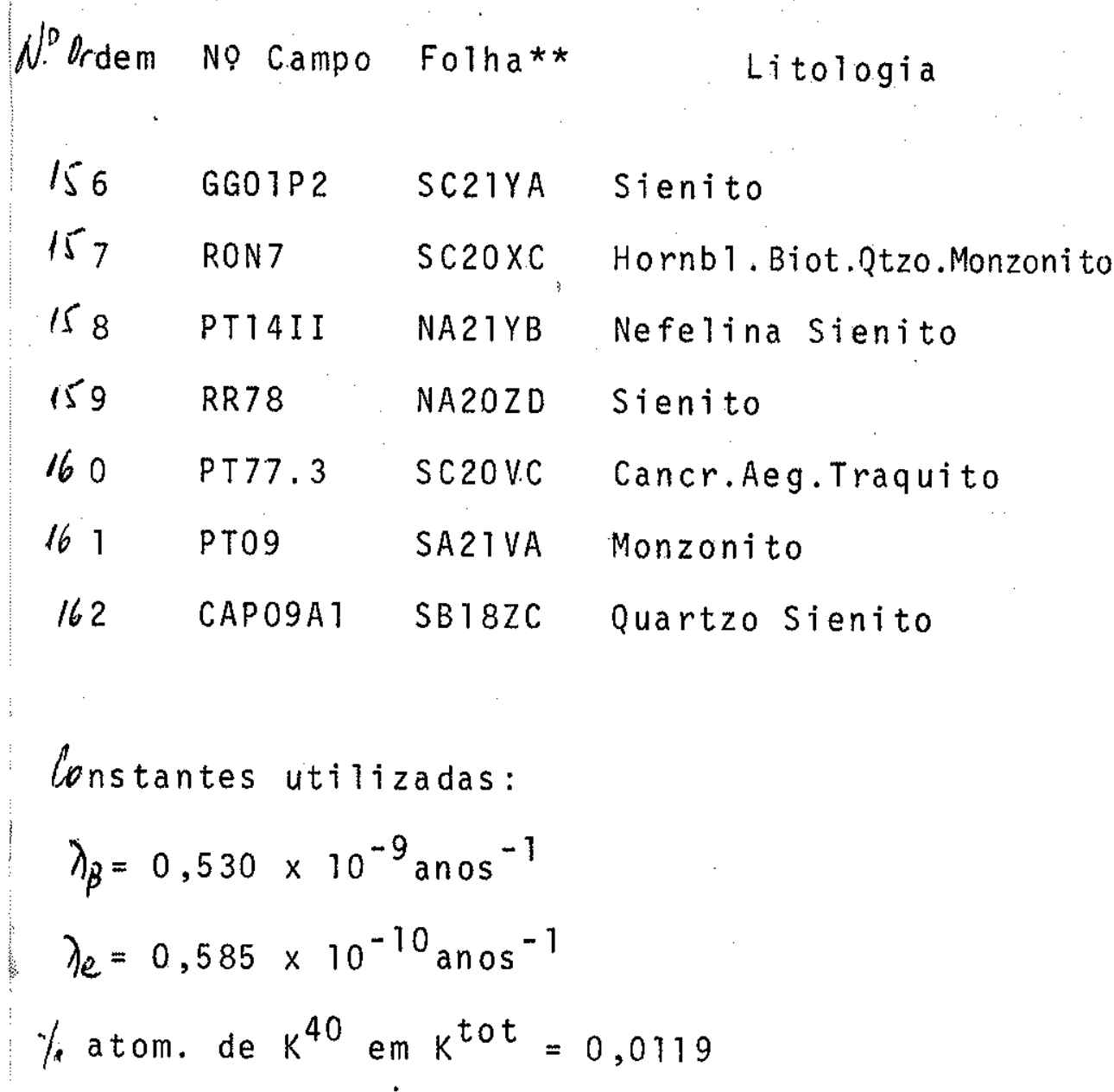

\begin{tabular}{|c|c|c|c|c|c|c|}
\hline Mineral & No Lab & $\% \mathrm{~K}$ & $\operatorname{Ar}_{\operatorname{rad}}^{40} \frac{(\operatorname{ccSTP})}{9} \times 10^{-6}$ & $\% A r: 0$ & $\begin{array}{c}\text { Idade } \\
(\mathrm{m} \cdot \mathrm{a} .)\end{array}$ & Ref \\
\hline Biot. & 2.911 & 4,05 & 260,80 & 2,09 & $1.169 \pm 57$ & 10 \\
\hline Biot. & - & 7,12 & 387,50 & 1,20 & $1.035 * * *$ & $5 M$ \\
\hline ortocl. & 3.059 & 10,08 & 547,50 & 1,60 & $1.026 \pm 28$ & $1 \mathrm{C}$ \\
\hline RT & 1.852 & 4,00 & 190,40 & 2,35 & $924 \pm 10$ & $5 B$ \\
\hline RT & 3.413 & 4,21 & 185,90 & 0,88 & $872 \pm 10$ & $1 M$ \\
\hline Feldsp. & 3.195 & $3,06^{\prime \prime}$ & 12,19 & 8,00 & $803 \pm 60$ & TG \\
\hline RT & 3.414 & $4,68^{*}$ & 47,43 & 5,65 & $238 \pm 3$ & $1 P$ \\
\hline
\end{tabular}

obs. :

* por Absorção Atômica

** Folna $1: 250.000$

*** erro analitico não disponível no trabalho original (Para referências, consultar Anexo 1) 


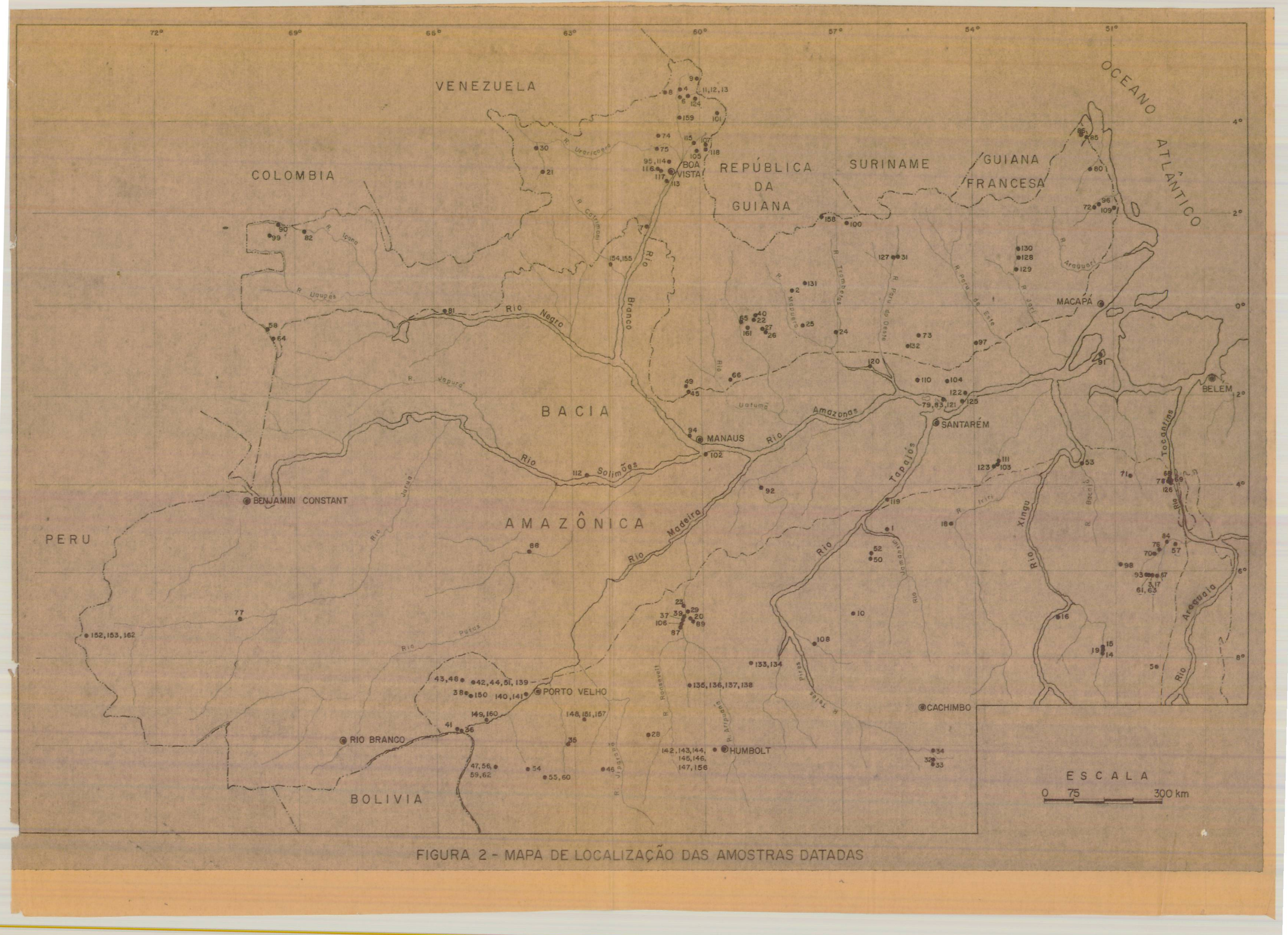




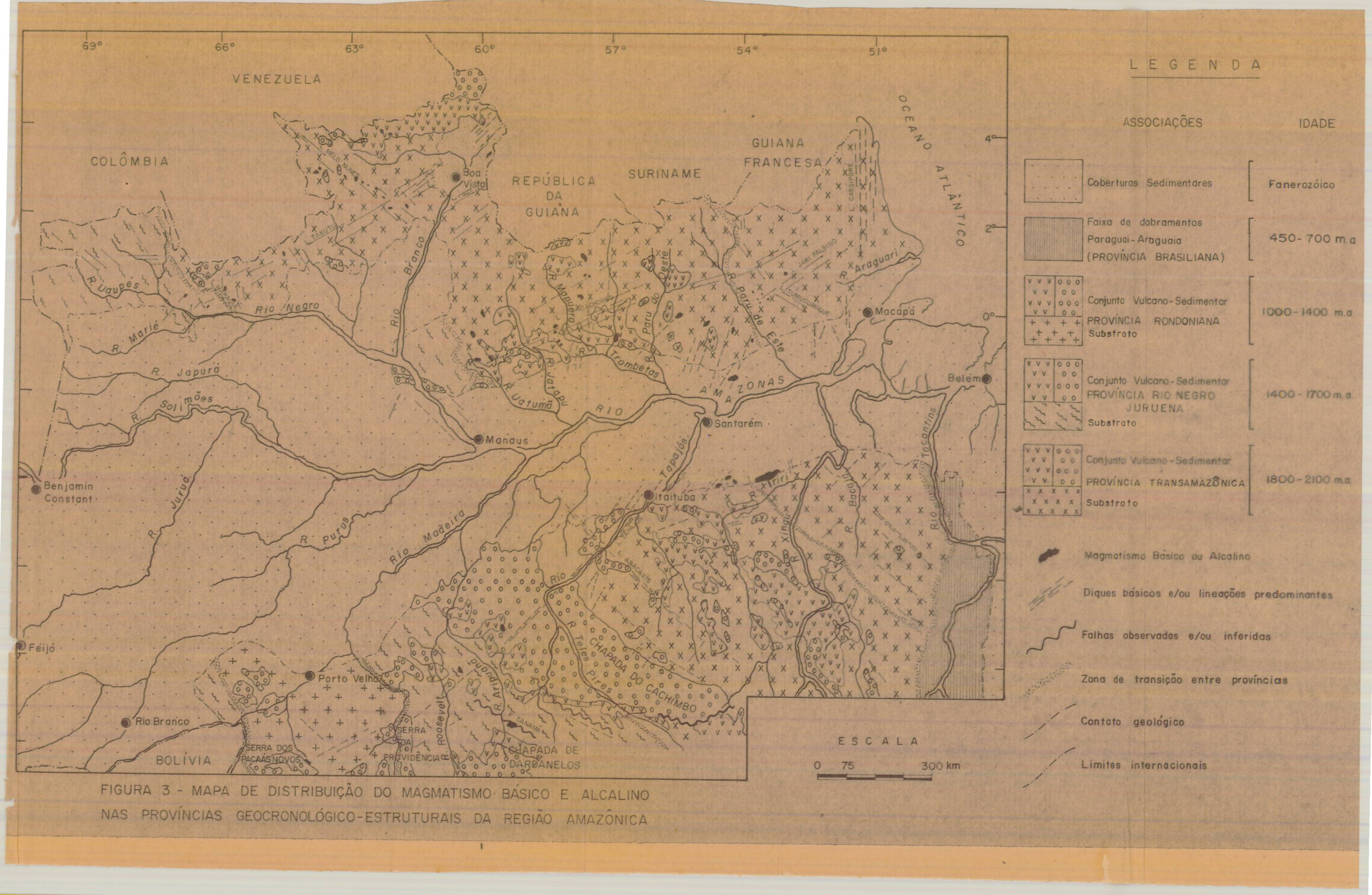

